Office of Fossil Energy

U.S. Department of Energy

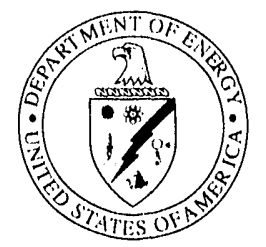

The PETC Review is published by the Pittsburgh Energy

Technology Center. Comments, suggestions, and topics for

future issues are welcome. Please send to the attention of:

Dr. Bernard D. Blaustein

PETC

P.O. Box 10940

Pittsburgh, PA 15236-0940

Phone: 412-892-6163

FTS: $723-6163$

FAX: $\quad 412-892-4604$

\section{PETCreview \\ StAFF}

EDITOR-IN-CHIEF:

Bernard D. Blaustein

Managing EDITOR:

Jamey Reiss

Senior Editor/Design Director:

Michael A. Tarquinio

EDITORS:

Jean Brown

Elizabéth Evans

Graphic Design, Layout:

Christie Biddle

L.B. Stephens

Gail Skinner

Photography:

Jim Schafer

PeTC Review Edtorial Board:

Thomas M. Torkos, Chairman

James T. Bartis

Bernard D. Blaustein

Fred R. Brown

Ralph A. Carabetta

Sun W. Chun

Hugh E. Cothran

Melvin C. Keller

Curtis McBride

David Nippert

Patrice L. Schlata

Joseph P. Strakey 


\section{TABLE OF CONTENTS}

PETC Review - Issue 4

Combustion 2000

The two parallel activities of this program-the Low-Emission Boiler System and the High-Performance Power System-are expected to dramatically improve the environmental performance of future coal-fired power plants and significantly increase the efficiency of coal-fired power production.

Liquid Transportation Fuels

from Coal, Part 2: Indirect Liquefaction

Along with the U.S. Deparment of Energy's Direct Coal Liquefaction Program, the Indirect Liquefaction Program seeks to meet National Energy Strategy goals to "reduce the cost, investment risks, and environmental impacts of producing liquid fuels from coal."

\section{A Computer Expert System} to Reduce Power Plant Emissions

The Coal Quality Expert computer system being developed in a Clean Coal Technology project is designed to predict the economic, operational, and environmental benefits of using commercially achievable cleaned coals. The system will help coal-burning utilities select the best-quality coal for their boiler.

PETC's Flow Analysis Laboralory Assisls Artificial Heart Research

Advanced flow diagnostic equipment developed by PETC researchers to study the flow fields in coal utilization processes is now being applied to study the flow of blood in artificial hearts.

\section{From the Director}

Update

Focus On

Highlights

RD\&D Awards

Publications and Presentations

Workshop Notes

Calendar of Events

\section{Reserved by $0 S_{1}$ APR 131992}

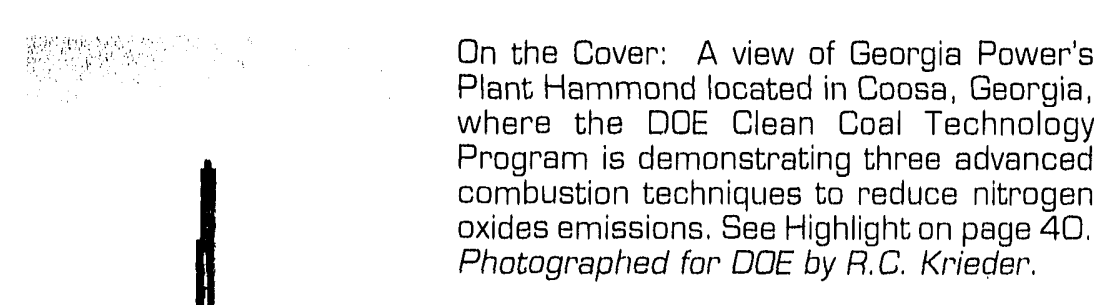

On the Cover: A view of Georgia Power's Plant Hammond located in Coosa, Georgia, where the DOE Clean Coal Technology Program is demonstrating three advanced combustion techniques to reduce nitrogen Photographed for DOE by R.C. Krieder.

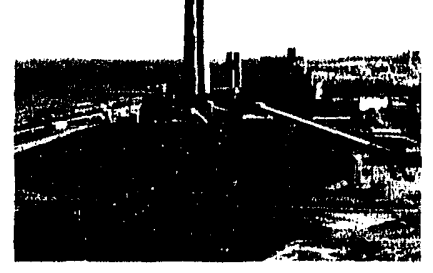




\title{
FROM THE DIRECTOR
}

\begin{abstract}
A
S I mentioned in the last issue, the U.S. Department of Energy recently released the first edition of the National Energy Strategy. This strategy is meant to lay the foundation for a more efficient, less vulnerable, and environmentally sustainable energy future. It highlights four major goals:

- Increasing energy and economic efficiency

- Securing future energy supplies

- Enhancing environmental quality

- Fortifying foundations through fundamental science and engineering research education and technology transfer
\end{abstract}

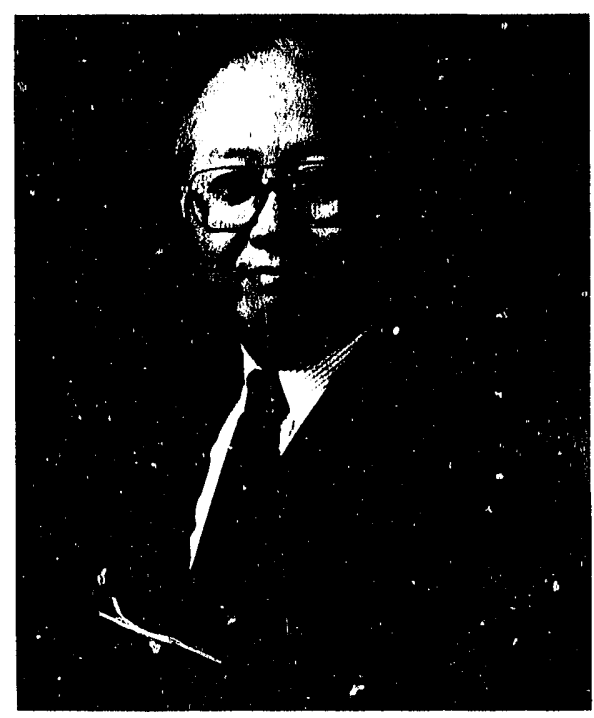

Sun W. Chun

I am pleased to say that the work we perform and manage at PETC strongly supports these goals and that we have already rnade major contributions in all of these areas. In this issue of the PETC Review, we present four articles on projects that are excellent examples of work related directly to each of the major goals.

The "Combustion 2000" article describes an exciting new program that is designed to achieve dramatic improvements in the efficiency and environmental performance of future coal-fired power plants, while maintaining electricity costs at or below current levels. The two major parts of the Combustion 2000 program are the engineering development of a "Low-Emission Boiler System," which applios relatively near-term technology to lower sulfur dioxide and nitrogen oxides emissions, and the "HighPerformance Power System," which uses advanced technology for significant efficiency increases. Industry has responded to our solicitations requesting proposals for both parts of the program and will undertake the challenge of developing these improved power systems by forming teams with the necessary skills and commitment to make this program a success. 
The matter of securing the nation's energy future was introduced in the last issue of the PETC Review with the first of a rwo-part article on "Liquid Transportation Fuels from Coal." We take that subject up again in this issue to discuss indirect liquefaction and the nation's ability to produce transportation fuels from coal. As some of our readers may know, indirect liquefaction is the only coal conversion technology that can produce performance enhancing additives (e.g., alcohols) for gasoline to increase octane ratings and to reducc. automobile emissions. Indirect liquefaction is also a particularly good route for producing high-cetane diesel fuels.

On the environmental front, a new and very promising approach to choosing the "correct" cleaned coal for a utility's boiler is being developed. A Coal Quality Expert computer program will, through a series of logic questions, help utilities pick the most economical coals to achieve required emissions levels. The Coal Quality Expert System will use data from an extensive series of test burns of coals cleaned by different means and to different degrees.

Finally, we offer the article "PETC's Flow Analysis Laboratory Assists Artificial Heart Research." Using equipment that is normally employed to study coal flow to instead study the flow of blood in artificial hearts, this project is one of the finest examples of terhnology transfer at work. The results of these studies may eventually help sustain human lives.

We continuously strive to fund research that would enhance both the efficiency of fossil energy technologies and the dependability of future energy supplies, while providing fur better environmental quality and reduced energy costs. In addition, we try to transfer and apply technologies to all areas of science and research. We are excited about the future and the possibilities open to us in the field of fossil energy; we will continue to share the results of those efforts with you as they develop.

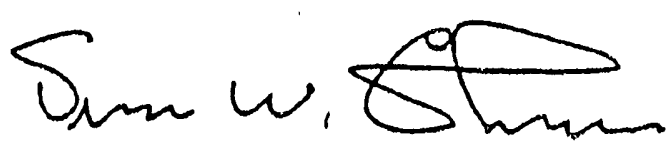




\section{COMBUSTION 2000}

Coal is this country's largest and most valuable energy resource, comprising over $75 \%$ of our proven energy reserves. These reserves are the energy equivalent to about 2 trillion barrels of cirude oil, more than double the world's known oil reserves. If we can use coal to reduce our dependence on imported oil, the United States can move toward greater onergy selfsufficiency, energy security, and economic stability. For this to happen, environmental problems associated with greater use of cocal need to bo addressed. This is the driving force behind Combustion 2000.

\section{The U.S. Electricity Supply}

$\mathrm{E}$ tons of coal per yoar or ahoul $85 \%$ of the coal usod in the United Slates. About $55 \%$ of all the oloctricity generalod in the Unilod stalos is produced from coul. To maintain and incroase coal's fulure rolo in the production of olocitric: powor, new combustion and omissions control technologies that offor low omissions, high officiency, and a high degreo of roliability ane required. "Theso lochnologies must cost no moro than those of the conventional tochnologios in use loclay.

Although many olocolric: mlilitios now have oxcoss gonoraling capacity, this silnation is expected to change during the coming docado. 'The comstruc:tom of now power plants has, for various economic and political roasons, heen less than expected and is nol koopong paco wilh incroasing olecilricily domand. Now pland construation will ovenlually havo lo incoroaso signilicantly, probably during tho lalo 1990 s and early 2 tst contury, to keop up wilh demand.

According to the linorgy Informalion Administralion, the not offecet of roliring agying power plands and of adding now plants that are now under comstrustion or lhal ano plammed lo (:omeo on lino by the mid-19g0s will bo lo raiso operable capuncily lo aboul 700 (iW. 'l'his increase in caparcily is oguivalont lo an ammual gerowth of atoun $0.5 \%$. Howeren, doring this period of slow growth in not supply, olocitricity demand is expociled to grow hy about $3 \%$, a figure comparable to the projected rate of ovorall ocomomic grow h. $\triangle$ load growlh of $3 \%$ represents a neod for $20,000 \mathrm{MW}$ por your of now capacily-tho opuivalont of huilding I wonty 1,000-MW planls mach year, Thorotoro, by 1995, modernto growth in olectricily domand and low growth in gonomating capacily will cal1se excess capacily lo disappoar. By tho yoar 2000 , significant shorthalls aro projected between power demand and generaling capacily.

Limissions regulations are axpocited lo sharply tightem over the mext clocade as a rosull of continuing concorn over acid min, air toxics (o.g., motals and polycycilic: aromalic:

hyclocanbons), global simalo shange, oxome pollution, and solid wasto disposal, 'l'horoloso, now powor pland anpacily will ho nooded al a limo whon incronsod prossures may como lo bear on powar producors lo lowor the omissions of' sulfur dioxido (SO) $)_{2}$, nitrogen oxides $\left(N()_{x}\right)$. and, porlaps, air toxics and camben dioxido (C,(), ). Systems to burn conal moro ciloanly and acomomically mast becomo avalabio wilhin tho

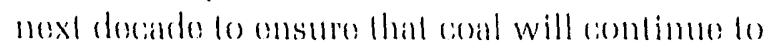

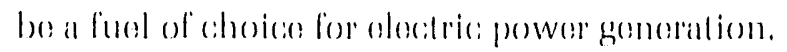
If these systoms can bo provided, the lonited Slales will bo ablo lo roulizo llon bonolits of using ils most abmomaml omorgy resomeros. 


\section{Enter Combustion 2000}

$\mathrm{E}$ PETC to lay the foundation for a new program that would address the needs of clean coal technology for the lirst decade of the 21 st century and beyond. This new program, called Combustion 2000, ains to develop the lechnology base that directly addresses the major threats to the continued use of coal for electric power generation. The specific goals of the program are to (1) dramatically improve the environmuntal performance of future coal-fired power plants and (2) significantly increase the elficiency of coal-fired power production. These goals will be achieved by conducting two parallel and complementary activities: (1) development of a Low-Emission Boiler System and (2) development of a High-Performance Power System.

\section{Low-Emission Boiler System}

The Low-Emission Boiler System (LEBS) will use relatively near-term technology to develop a power plant that has dramatically lower $\mathrm{SO}_{2}$, NO ${ }_{x}$, and particulate emissions than do today's plants and that will also keep the cost of electricity comparable to that of conventional technology (e.g. a pulverized coal boilor with electrostatic precipitator and wet limestone scrubber). Recent lechnological advances have been made in the combustion and flue gas cleanup areas. Examples of combustion technologies that are becoming available incilude combustion modifications for minimizing $\mathrm{NO}_{\mathrm{x}}$ emissions such as staged air, staged fuel (reburning), and improved high-efficioncy, lowNo, burners; and slagging and vortex combustors capable of rejecting a significanl fraction of the ash before it enters the boiler.

Some of these advances are the result of scientific rosearch conducted over tho past 20 years. For example, applications of research on the chemistry of nitrogen compounds ciuring combustion are appearing in full-scale, coalfired ulility planls. This resoarch indicalos that advanced combustion controls alone should be capable of limiting $\mathrm{NO}_{x}$ amissions to $0.2 \mathrm{lb}$ $\mathrm{NO}_{2} / 10^{6} \mathrm{Btu}$ in now coal-fired utility boilers. 'This compares wilh a current U.S. New Source Porformance Slandard (NSPS) of $0.6 \mathrm{lb} \mathrm{NO} \mathrm{N}_{2} / 10^{6}$ Blu for biluminous coal. In some Western European countries, $\mathrm{NO}_{\mathrm{x}}$ emissions standards have already been reduced to the range of $0.2 \mathrm{lb}$ $\mathrm{NO}_{2} / 10^{6}$ Btu. Fairly expensive flue gas cleanup systems dedicated to $\mathrm{NO}_{\mathrm{x}}$ controt are the only technically viable options presently available for meeting such stringent $\mathrm{NO}_{\mathrm{x}}$ emissions standards. By focusing on advanced combustion controls, the LEBS program offers a much lower cost alternative for extensive reductions in $\mathrm{NO})_{x}$ emissions.

Slagging combustors, similar to the type originally developed under DOE sponsorship in the mid-1970s for magnetohydrodynamics (MHD) applicalions, have been demonstrated on industrial boilers. In addition to high carbon conversion efficioncy, slagging combuslors have been shown to achieve low $\mathrm{NO}_{x}$ emissions and coal ash removals of up to $90 \%$ upstream of the boiler. This high ash rejection can result in improved boiler tube environments that, in turn, could lead to tighter tube spacings, improved heal exchange, smaller boiler size, and lower cost. The vitrified ash produced by slagging combustors is also a more environmentally benign waste product bocause the melals incorporaled in this form of ash are not expocted to bo loachabla.

Emerging Flue Gas Cleanup Technologies. The Combustion 2000 Task Group reviewed over 20 flue gas cloanup lechnologios that are now under development. Among the moro promising candidates for the Low-Emission Boilor System are advanced limestone scrubbing (e.g., forcod oxidation, with or withoul an adipic: acid additive), NOXSO (see PETC Review, Issue 2), Tung fluo gas desulfurization, and WSA-SNOX. 'These four' lechnologies are discussed below.

- Forced oxidation limestone scrubbing onhanced with an adipic acid additive, already in use in Europo, represents an improvement lo commercial wet scrubbers. 
It produces a gypsum by-product that may be sold for profit or disposed of safely and inexpensively in a landfill.

- The NOXSO process is a dry flue gas treatment process capable of removing both $\mathrm{SO}_{2}$ and $\mathrm{NO}_{\mathrm{x}}$. These species are removed from the flue gas as the gas passes through a fluidized bed of solid adsorbent at $120^{\circ} \mathrm{C}$. Spent sorbent is regenerated by heating to desorb $\mathrm{NO}_{\mathrm{x}}$ and treating it with a reducing gas, which yields a mixture of $\mathrm{SO}_{2}$ and $\mathrm{H}_{2} \mathrm{~S}$ that is then converted to elemental sulfur in a Claus reactor. The $\mathrm{NO}_{\mathrm{x}}$ stream is recycled to the boiler where it dissociates to nitrogen and oxygen. The NOXSO process generates little waste by maximizing production of salable products. A 5-MWe proof-of-concept test is underway at Ohio Edison's Toronto Station, and a 100-MWe demonstration is in the design phase under the Clean Coal Technology Program.

- The Tung process is a highly efficient regenerable wet scrubbing process that can remove $98 \%$ of the $S \mathrm{O}_{2}$. It is similar to the comniercial sodiuin-based Wellman-Lord scrubber; however, the bisulfite solution is regenerated by extraction with an aqueous amine. $\mathrm{SO}_{2}$ is steam-stripped from the relatively small volume of amine solution, which requires only a fraction of the energy that would have been needed to steam-strip $\mathrm{SO}_{2}$ from the aqueous bisulfite solution itself. Installation and lesting of the Tung process on a 3-MWe flue gas slipstream at Niagara-Mohawk Power Company's Dunkirk Station, scheduled for 1992, will demonstrate this process on a coal-generated flue gas.

- In the WSA-SNOX process, $\mathrm{SO}_{2}$ is catalytically oxidized to $\mathrm{SO}_{3}$ and recovered as concentrated sulfuric acid in an aircooled, falling-film condenser made of glass. No raw materials are used, and no waste products or wastewater are generated. A WSA-SNOX demonstration project was selected for funding under Round 2 of the Clean Coal Technology Program.

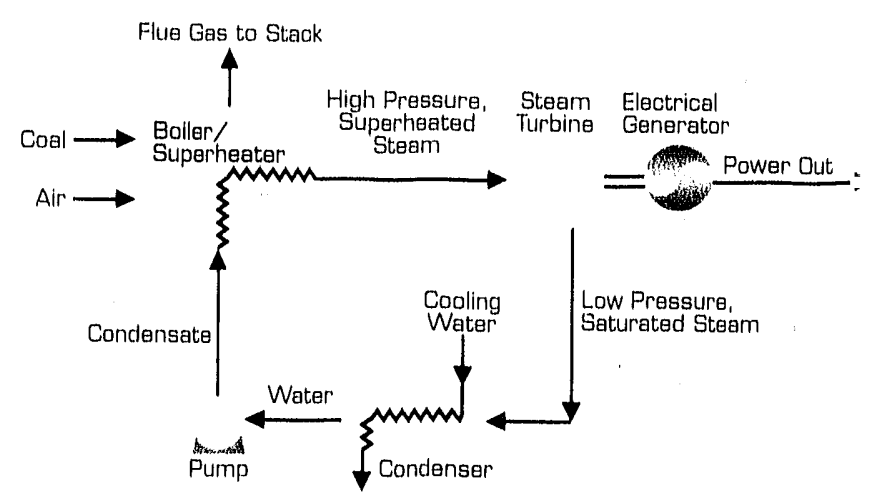

(a) Conventional Coal-Fired Rankine Cycle for Power Generation

Figure 1. (a) Conventional (above) and (b) High-Performance (right) Power Systems.

Candidates for increasing the removal of particulate matter from flue gas are advanced electrostatic precipitators and improved fabric filters. Either emerging technology is capable of removing more of the fine particulates (under 10 microns) that are present in flue gas from coalfired plants. Because many metal species and complex organic substances are adsorbed onto the surfaces of fine, respirable particulates, increasing the removal of fine particles will also reduce the emission of potentially harmful substances into the atmosphere.

Another important objective of the LowEmission Boiler System is increased thermal efficiency. It is anticipated that efficiency improvements (to a level of between 38 and $42 \%$ ) brought about by creatively integrating boiler, combustor, and flue gas systems will help offset the costs of advanced components. These improvements can come about through improved steam conditions attainable by using better heat exchange materials; greater lowtemperature heat recovery from flue gases, and higher temperature flue gas desulfurization. The latter can eliminate the need for reheating stack gases to achieve acceptable plume buoyancy. 


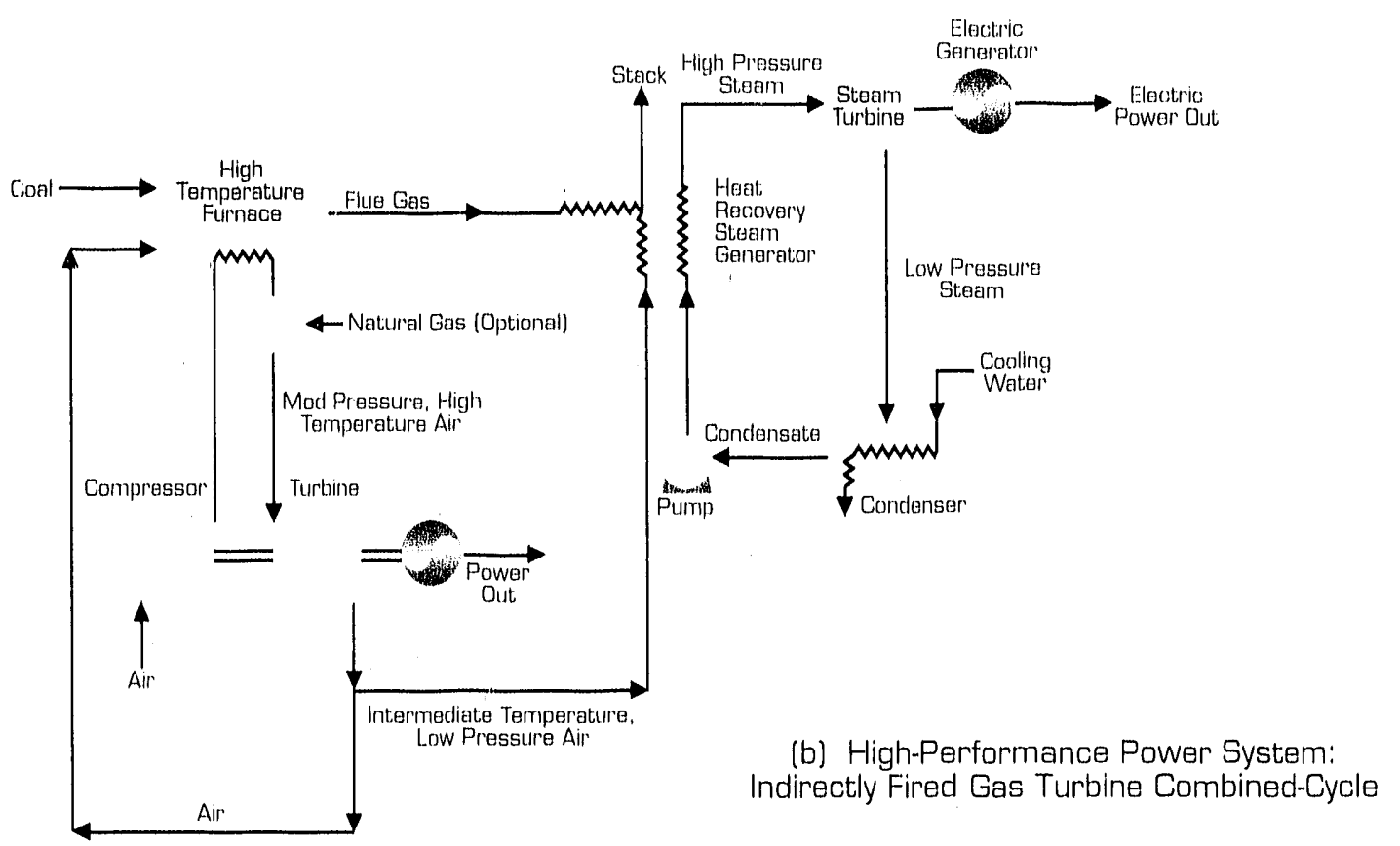

Modular design will also be emphasized, wherever appropriate.

The Low-Emission Boiler Systom will attempt to rethink coal-fired boiler design while using the new technologies that are now becoming available through research and development. Environmental control will be integrated with combustion, heat transfer, and all of the other aspects of boiler design. The new power system will outperform conventional plants; however, it will resemble today's plants sufficienlly to make it readily acceptablo by the olectric: utility industry.

\section{High-Performance Power System}

The second project to be conducted in parallel as part of the Combustion 2000 program may be among the most challenging offorts to be undertaken by DOE's Office of Fossil knergy. Designated the High-Performance Power System (HIPPS), the system would use advanced technology to produce olectricity from coal with an overall thermal officioncy of $47 \%$ or higher. This compares to an efficiency of aboul $35 \%$ for today's conventional plants. In addition, because it is targeted for commercial use somewhat later, the envirommental porformance goals for HIPPS are more stringent than those for the Low-Emission Boilor Systom. Emissions of $\mathrm{SO}_{2}, \mathrm{NO}_{x}$, and particulales would be lower; and, because of the higher officioncy, emissions of $\mathrm{CO}_{2}$ will be reduced significantly by between 25 and 30 percont. Thus, HIPPS directly addresses concorns over $\mathrm{CO}_{2}$, which has been associated with global climato change. Flue gas clesulfurization wastes will bo virtually eliminated by using cileanup processes that genorate usablo by-products. Equally important, the above porformance will be achievod while aiming to reduce eloctricity costs by $10 \%$ compared with current systems.

Technology Candidates. A number of highporformance combined-cycle systems are already under development with DOE sponsorship, including (1) combined-ciycles gasification-fuol coll, (2) combined-cycho gasification-gas lurbine, (3) direct-firod gas lurbino combined cycle, and (4) MHD combined cycilo technologies. PE'T'C has conductod studies lo dotormine if thore ares other potontially allractive systems whose 


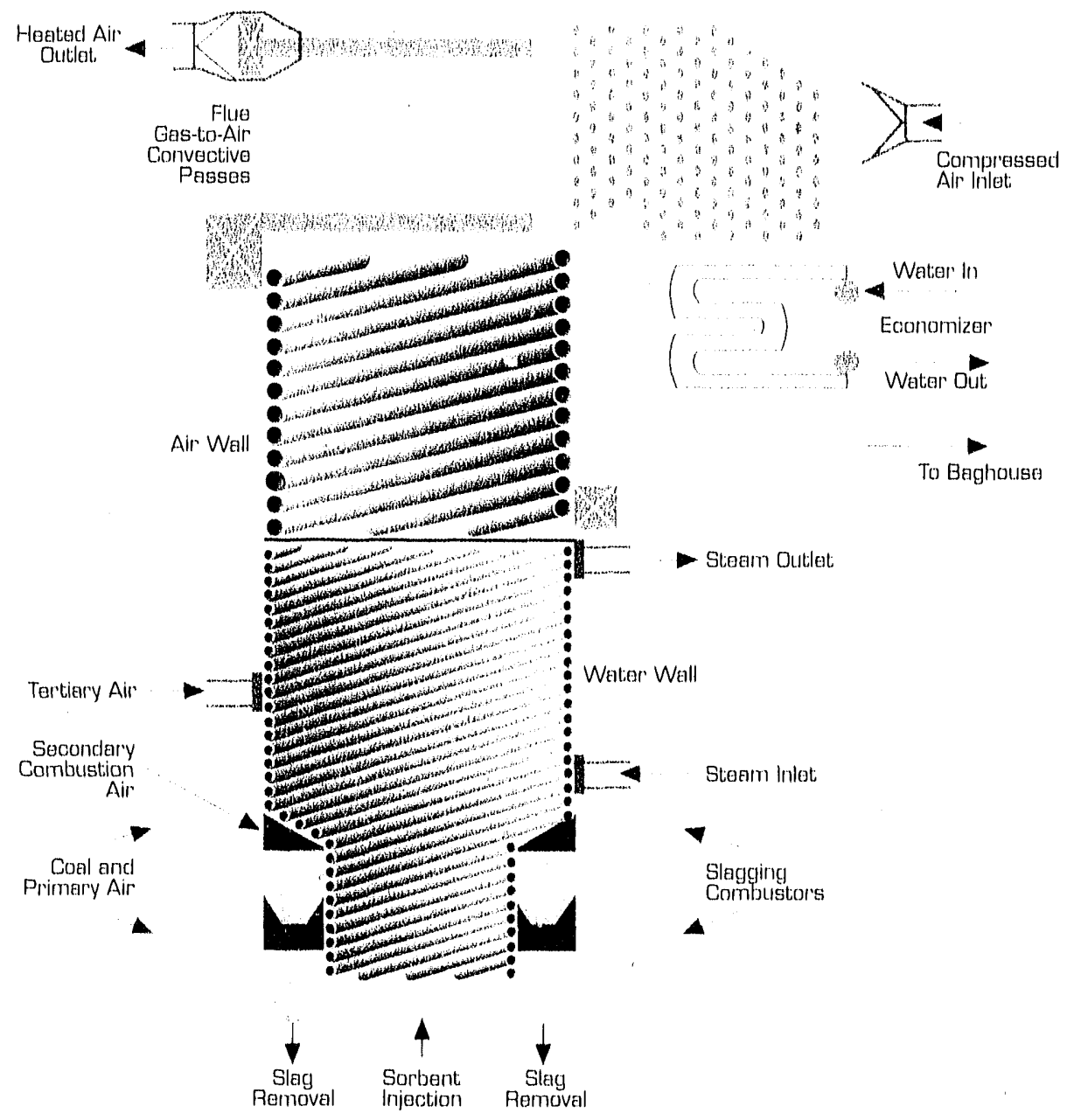

Figure 2. Artist's conception of High-Temperature Advanced Furnace (HITAF). In this design, the water wall would be used to superheat steam for the steam cycle.

development should be supported. A leading candidate is a combined-cycle systom that uses a gas lurbine driven by a working fluid separately heated in a novel high-temperature advanced furnace (HI'T'AF). A supplomentary clean fuel can be used to boost the temperature of the working fluid in order lo lake advantago of high-temperature, high-efficiency gas lurbines. Energy in the gas turbine exhaust is used to run a steam cyclo. As with other highperformance systems, the new HIPPS can provido high thormal officioncy and roduced omissions of $\mathrm{CO}_{2}$.

The tochnological risk associaled with HIPPS is rolatively low. Other than arlvanced fluo gas cleanup lochnology nooded lo achiovo vory low emissions, the only terhnology slopent is tho
HITAF'. Another advantage of HIPPS is that the powor system will be much more like the facilities in use today than are some of the other advancied systems. Noither a gasilier nor a system to clean the hot gesification products (fluo gas) is recpuired. A simplified schematic of HIPPS is shown in Figure 1(b). Also, Figure 1(a) is a diagram of the coal-fired Rankine cycle, the type of cycio used by conventional power plants. The reguired lurbines neoded for HIPPS are already commercially available, Moroover, features are built inlo HIPPS that mako this systom ovolutionary (i.o., a version of this systom using cool and natural gas co-firing can oven bo buill loday using availablo hightomparature furnater lochonology). If there is a noed lo use nalural gas for moro valuablo ipplications, tho amount of gats usod would 
bo roduced as advances are mado ha hightemporalure furnace tochnology.

An arlist's conception of what the furnaco might look like is shown in ligure 2. 'The purpose of the furnace is to heat the ciloun working fluidalr-lo prescribed turbino inlot tomperaluros. As in a boilor, the furnace will comlain a radianl and a convective section (seo PETC Review, Issue 2, "Combustion Primer" for more information). However, because the hoat transfor surfaces will be at a higher tomperature than in a boiler, the combustion process and hoat ansfer system must bo closely controlled and malchod. Engineering analyses have shown signilicant improvements in thermal efficiency for this HITAF concept (see Figure 3).

The design of the heat translor surface may bo quite unlike that used in conventional boilers or furnaces. The heat transfer malorials will bo under low stross because they will contain working fluid under the relatively low pressures (about 150-200 psi) of the turbine inlot. The use of heat transfer geometries other than tubes is a strong possibility. This could be a big advantage because advanced alloys or coramics will neod

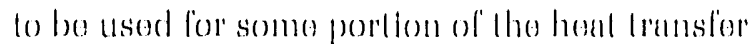

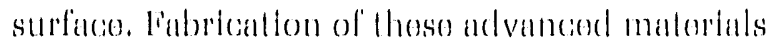

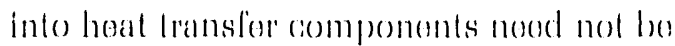
limilod lo the convontlomal shapos asod for boilors.

NO, omisstons will bo sharply roduced by regulating the rato of fuol and all addition into tho furnace and by combelling the lomporalares profilu of the combustion proclucis. There is also lino likelihood ol significantly roducing $\mathrm{SO}_{2}$ omissions by injociling a sorbont lnto the controllect-lomporaluro furnaco. Limissions controls will nogd to bo well inlogratod with tho combustion and hoal transfor procossus.

\section{Program A.pproach}

\section{$T$}

Lablo a summarizos tho rolationship of tho Low-Emission Boilor Sysion and the HePPS projects with rospese to tho liming for commercial roadiness; efficiency, omissions, and cost of olocitricity objoctives; and koy dosign foatures, Signilicant sysloms devolopment offorts will be rocutiend for both tho Low-

Figure 3. High-Performance Power System efficiency.

49.5
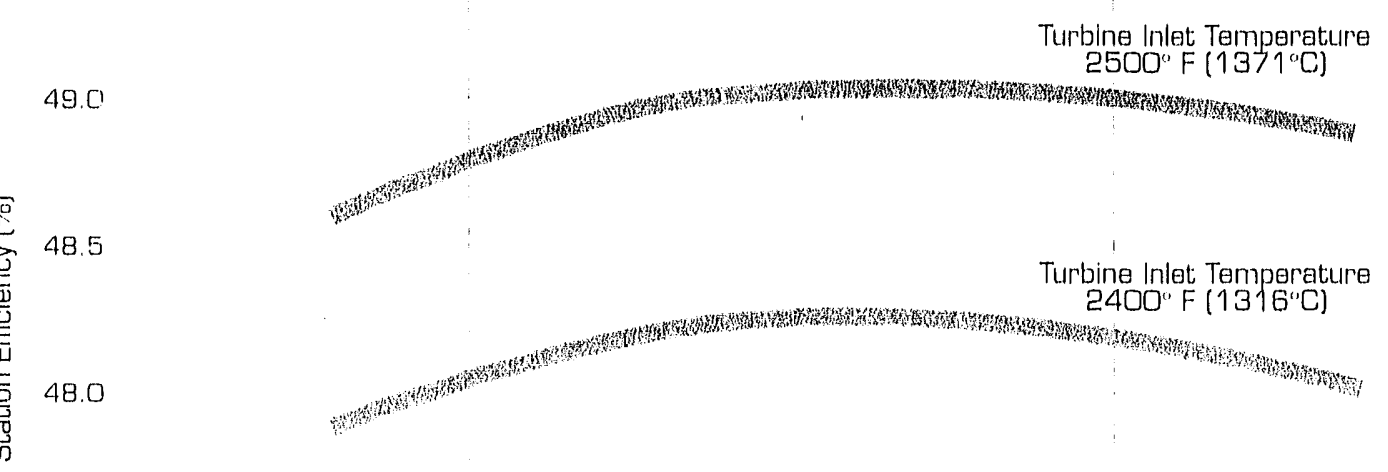

47.5

47.0

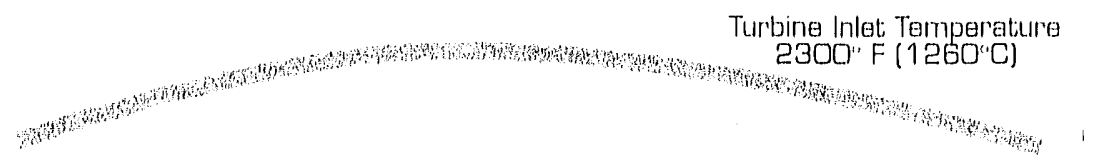

Q

8

10

12

Ges-Turbine Pressures Ratio 


\begin{tabular}{|c|c|c|}
\hline & Low-Emission Boiler System (LEBS) & High-Performance Power Systeln (HIPPS) \\
\hline Timing & $\begin{array}{l}\text { Design base for initial commercial } \\
\text { plants available by } 200(.) \text {. }\end{array}$ & $\begin{array}{l}\text { Design base for proof-of-concept } \\
\text { plant available by 1999; commercial } \\
\text { readiness by } 2004 .\end{array}$ \\
\hline $\begin{array}{l}\text { Thermal } \\
\text { Efficiency }\end{array}$ & $\begin{array}{l}\text { Uses an advanced version of a } \\
\text { conventional steam power plant } \\
\text { cycle to achieve efficiencles of } \\
38-42 \% \text {. }\end{array}$ & $\begin{array}{l}\text { Uses an indirectly heated gas-turibine } \\
\text { combined cyole that requires the } \\
\text { development of a high-temperatura } \\
\text { advanoed furnace (HITAF) to achilave } \\
\text { efficiencies of } 47 \% \text { or higher. }\end{array}$ \\
\hline $\begin{array}{l}\text { Emissions } \\
\text { Controls } \\
\text { Technologies }\end{array}$ & $\begin{array}{l}\text { Utillzes emissions controls cechnologies } \\
\text { now in advanoed development or } \\
\text { demonstration to achieve } \mathrm{SO}_{2}, \mathrm{NO}_{\mathrm{x}^{\prime}} \\
\text { and particulate emissions of } \\
1 / 3,1 / 3 \text {, and } 1 / 2 \text {, respectively, } \\
\text { of the current New Source } \\
\text { Performance Standards (NSPS). }\end{array}$ & $\begin{array}{l}\text { Utilizes similar, but more refined, } \\
\text { versions of the emissions controls } \\
\text { technologies used by LEBS to } \\
\text { achieve } \mathrm{SO}_{2,}, \mathrm{NO}_{x^{\prime}} \text { and particulate } \\
\text { emissions of } 1 / 4 \text { of the current } \\
\text { NSPS (may also use "breakthrough" } \\
\text { technologies, if available). }\end{array}$ \\
\hline $\begin{array}{l}\text { Process } \\
\text { Improvements }\end{array}$ & $\begin{array}{l}\text { Utilizes emerging improvements in } \\
\text { pulverized coal }(P C) \text {-fired } \\
\text { furnace design to reduce costs. }\end{array}$ & $\begin{array}{l}\text { Utillizes a new PC-fired HITAF to } \\
\text { achieve high performance and to } \\
\text { reduce oosts. }\end{array}$ \\
\hline $\begin{array}{l}\text { Target } \\
\text { Cost }\end{array}$ & $\begin{array}{l}\text { Cost of electricity target no higher } \\
\text { than current coal-fired plant } \\
\text { designed to meet NSPS. }\end{array}$ & $\begin{array}{l}\text { Cost of electrioity target } 10 \% \text { below } \\
\text { that of current coel-fired plant } \\
\text { designed to meet NSPS. }\end{array}$ \\
\hline
\end{tabular}

Table 1. Comparison of LEBS and HIPPS.

Emission Boiler System and the HIPPS. 'The now power plants will be designed from the ground up with advanced technologies in mind. All major plant subsystems (o.g., coal preparation and feeding, combustion, heat transfer, emissions controls, ash management, waste disposal, and power cycle configuration) will be totally integrated.

The Low-Emission Boiler System Program will have four phases:

- Systems analysis/R\&D plan formulation and component definition/proliminary commercial generaling unit design

- Engineering developmont/subsystem lesting

- Proof-of-concept (POC) plant design

- POC plant construction/operations

Systems analysis will include concepl development and R\&D planning for the entire program. System design assessments will be mado poriodically to ovalualo tho progross of the work. The engineering dovelopment phase of the program will include component dovelopment and testing of the plant subsystoms on a relatively small scale-about 3 to 5 MWo, Sufficient lime will bo allowed for enginesering development so that major technical issues are resolved beforo proceoding with the POC plant, which would have a raling of at loast $20 \mathrm{MWO}$. The POC testing and ovaluation, which is to bo completed in Fiscal Yoar 2000, will serve as the dosign basis for a commercial-scale planl.

Development of the Low-Emission Boiler System will requiro expertise in a broad rango of technical areas (o.g., boilor dosign, combustion, and flue gas cleanup). 'l'heroforo, loaming of contraciors was encouraged to onsure that this oxpertiso will be available. 'Tho uso of' interdisciplinary loams is consistent with tho systems approach and will promote communicaltion among combactors lo solvo the problems that aro corlain lo ariso, bach loam will be given rosponsibility for doveloping the 
full system. Equally important, the team members will be allowed to retain a proprietary position in the technology that is developed and will be required to cost-share in the overall development. This feature will motivate postprogram commercialization, which is a key project objective.

A solicitation that covered the entire four-phase Low-Emission Boiler System program was issued on December 3, 1990, and closed on April 1, 1991. Multiple awards are expected by December 1991. Program evaluation with probable down selection to fewer teams will occur after Phases I and III. The anticipated program schedule is shown in Figure 4.

Development of the HIPPS includes three phases: (I) concept definition and preliminary $\mathrm{R} \& D$; (II) engineering development and testing/ prototype plant design; and (III) construction, operation, and evaluation of a commercial prototype plant. The three-phase program will culminate in testing of a 40- to $80-\mathrm{MWe}$ commercial prototype in 2001. The major activities for Phase I are systems analysis; engineering analysis; preliminary experimental work; design of a commercial-scale generating plant; and formulation of an engineering research, development, and test plan for
Phase II. The engineering development phase includes furnace development, flue gas cleanup process testing, component and subsystem integration, and system control. A major part of engineering development will be to design, construct, operate, and evaluate a hightemperature furnace with a capacity in the range of 50 million Btu/hr.

Development responsibility for HIPPS (as with the Low-Emission Boiler) lies within the Office of Fossil Energy's Advanced Combustion Technology Program. To ensure overall program success, complementary research will be conducted in the Flue Gas Cleanup and Coal Preparation Programs, as well as in Advanced Combustion Technology. Flue Gas Cleanup will focus on advanced $\mathrm{SO}_{2}$ and particulate matter control. Supnorting research in Coal Preparation ivill focus on removal of selective mineral species from the coal. For example, the advanced alloys and/or ceramics to be used in the HITAF may be attacked by certain inorganic constituents (e.g., alkali-metal compounds) present in the coal ash. If so, then a reasonable approach would be to selectively remove these from the coal before comivustion. Supporting research in Advanced Combustion would include studies on $\mathrm{NO}_{x}$ control, ash management and, perhaps, in situ sulfur control.

Figure 4. Program schedule, Low-Emission Boiler System.

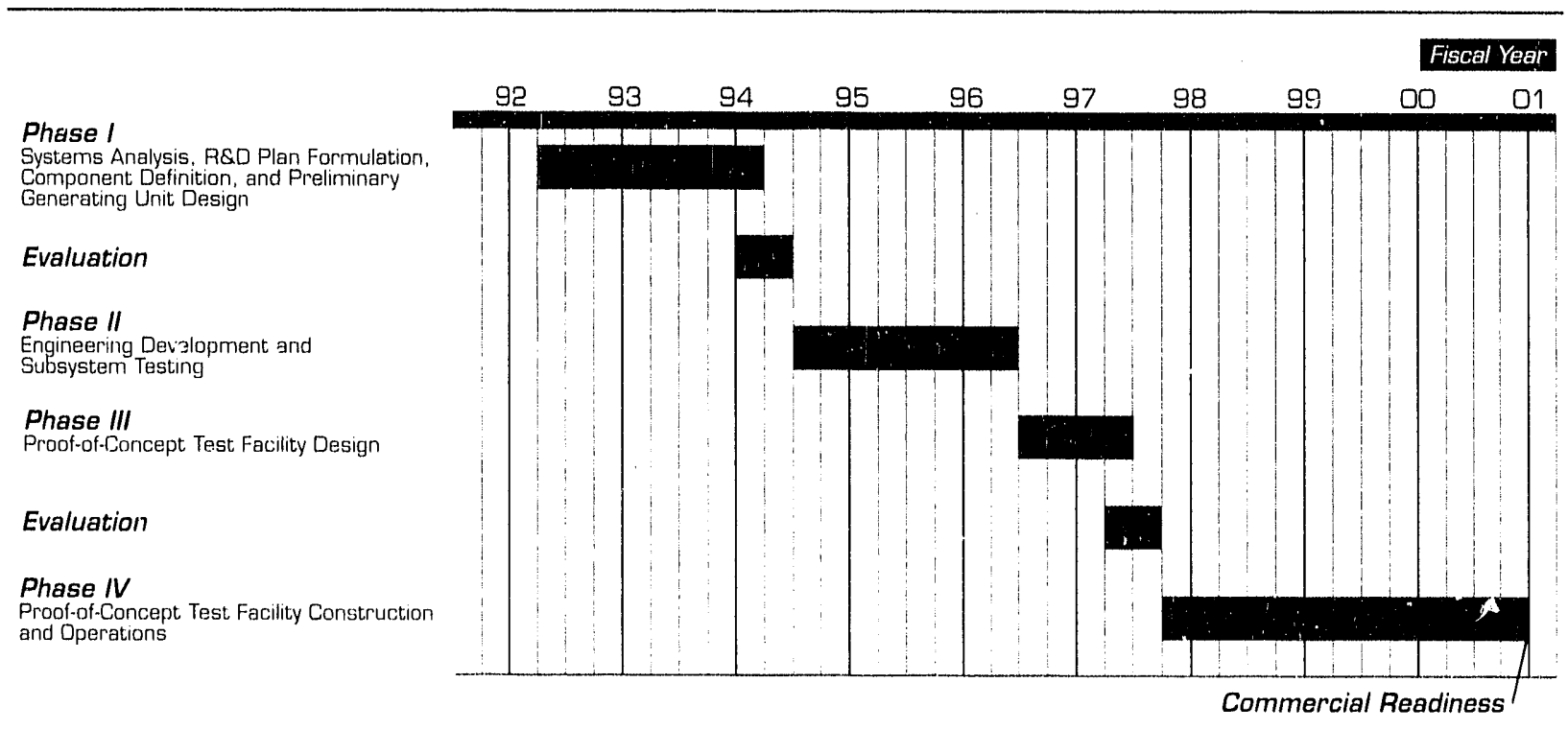




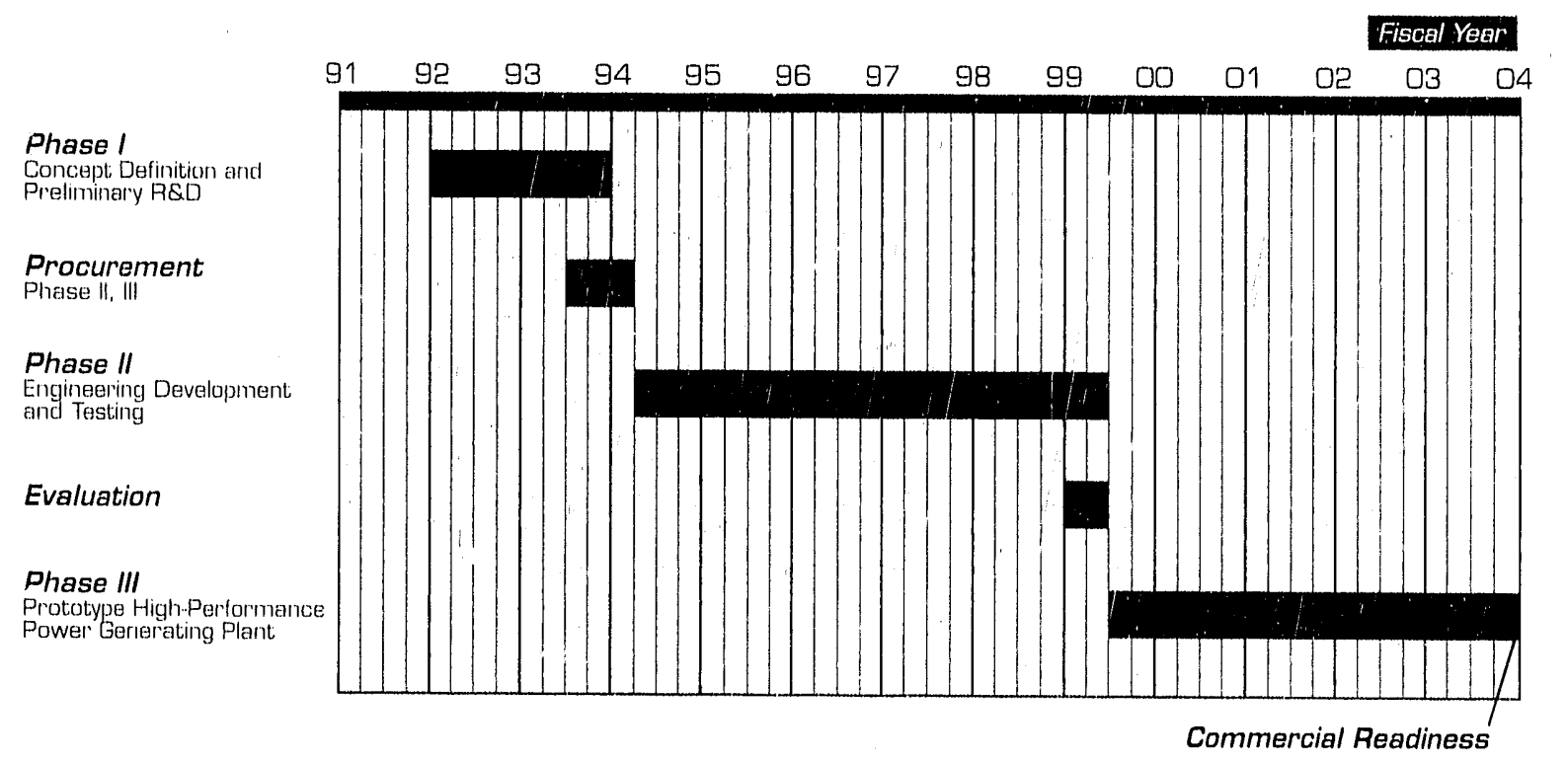

Figure 5. Program schedule, High-Performance Power System.

The program will also include extensive research on advanced materials suitable for high-temperalure heat exchange. As in the LowEmission Boiler System, il will probably be advantageous to use a lype of combustor (e.g., slagging or vortex) that provides significant ash rejection (removal) upstream of the heat exchange surface. Reduced ash levels may provide an improved environment for the heat transfer surfaco and can result in potentially higher reliability and lower costs. The findings of current research on capturing sulfur within the combustion chamber suggest that, within the development time for the HIPPS, techniques for substantial sulfur capture will be available. If so, then the flue gas scrubbing step could? function more as a "polishing" operalion, resulting in potentially lower costs for sulfur control.

A Program Research and Development Announcement (PRI)A) for Phase I of the HIPPS Program was issued on September 19, 1990, and closed on December 19, 1990. Selection of three U.S. industry loams was announced to the public: on June 12, 1991. 'The leams are:

- Foster Wheeler Developmenl Corporation, livingston, Now Jorsey

- Bechlel Corporation

- Research-Collroll
- TRW, Inc.

- $\Lambda$ Research Division of Allied-Signal Corporation

- United Technologies Research Center, East Hartford, Connecticut

- UTC Turbo Power and Marine

- Bechlel Corporation

- Power Technology International (a consortium of PSI Technology Company and Reaction Engineering International)

- Oak Ridge National Laboratory

- Univorsily of North Dakota Energy and Environmental Research Center

- Westinghouso Electric Corporation, Orlando, Florida

- Babcock and Wilcox Company

- Fluidyno Engineering Corporation

- Allison Division of Gencral Motors

- Allogheny Power System

- Sei-Tece, Inc.

- ERC, Inc:

Avards for Phase : will be mado late in Fiscal Year 1991. Phase II will be iniliated with a competilive solicitalion in 1993. There will bo a phase transition evaluation for down selection after 
Phase II. No separale solicitation will bo issued for Phaso III. An anlicipated projoct schodulo is shown in Figure 5.

\section{Summary}

$\mathrm{T}_{\mathrm{h}}$ o Combustion 2000 program will holp advance direct coal utilizalion lechnology inlo tho 21 st contury. 'The Low-Emission Boiler' System rethinks coal-fired boiler design for minimum emissions al the lowest possiblo cost and applies emorging combustion and fluo gas cleanup system lechnologies. The HIPPS program is a comprehonsive R\&D effort that offers significant elficioncy and environmental benefits. While higher in tochnicial risk than LEBS, the HIPPS program is designed to bo significantly lower in lechnical risk than other high efficioncy syslems being devoloped, and will yield an operalting plant that will closely resemble loday's power plants. Most importantly, the HIlPSs wili :ncrease efficioncy by al leasl one-third compared wilh loday's plants. Combustion 2000 promises 10 bo a challenging and exciting undertaking and one that will have a strong positive offecil on both the environmenlal quality and onergy securily of this nation.

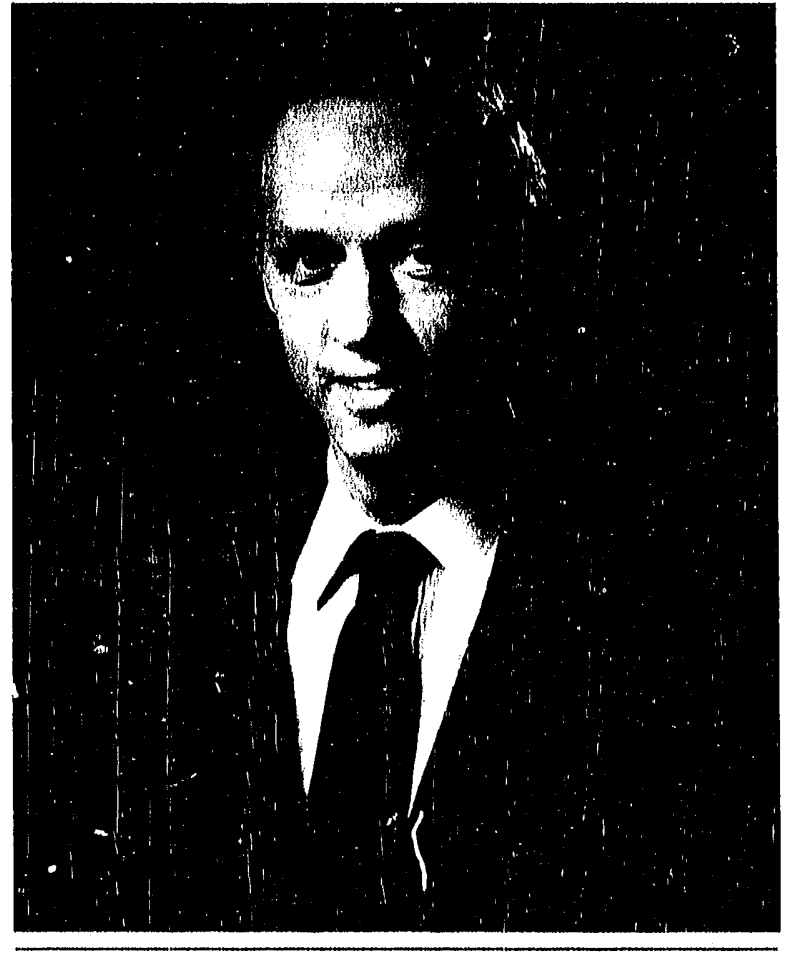

Lawrence A. Ruth is Director of the Coul Ulilization Division al PETC. Ho manages DOEE's Advenced combustion Ter:hnology and Allem?'alive Fuels Vlilization Programs as woll as Advanced Ressecureh progerams doaling wilh cooce! preparation, combustion, and amissions control. He joined Plel'c' in 1988 after 16 veans in privede industry, with Exxon Research and bingincering Compony and Energy and Einvironmental kescenteh Corporalion. Most of his exporionee involves combustion and funels lechomology, including conlrol of combustion-

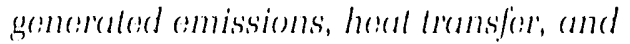
fluidized bed processing. He has over" 5e) publications and pouperss. Dr. Rulh has a Ph.l). in chomical onginesering from the City Universily of New York, and bachelor's and merster's deggreses in shemical ongineering from City Collegen of New York. 


\section{LIQUID TRANSPORTATION FUELS FROM COAL Part 2: Indirect Liquefaction}

In the last issue of the PETC Review, we discussed the U.S. Department of Energy's (DOE's) rationale for seeking alternative sources of liquid transportation fuels (see sidebar) and described the direct coal liquefaction research and development (R\&D) program. In this article, we examine the history as well as current and future research activities for DOE's Indirect Liquefaction Program.

Our focus will be on the use of indirect liquefaction for the production of hydrocarben fuels. We also briefly review our R\&D activities for producing oxygen-containing fuels and fuel components.

Using today's best available direct liquefaction technology, a high-quality synthetic crude oil can be produced from coal. This product would be competitive with crude oil (West Texas Intermediate) priced at between $\$ 35$ and $\$ 40$ per barrel. The per-barrel costs of producing liquids using indirect liquefaction are considerably higher. However, the products of indirect liquefaction resemble petroleum products that have already been refined and are ready for use. Consequently, indirect liquefaction products carry a higher value, which is not easily measured in terms of crude oil equivalent prices. At present, our best estimates indicate that product costs, from either direct or indirect liquefaction, are nearly equal when measured on a crude oil-equivalent basis. Most importantly, the very different product slates produced by indirect liquefaction are complementary to those obtained using direct liquefaction. For example, an indirect liquefaction plant can be designed to produce a high-quality diesel fuel, and direct liquefaction yields a product that is best suited for the manufacture of a high-quality gasoline. Using another catalyst and reactor design, an indirect liquefaction plant can be configured to produce high value oxygenates that can be used to enhance gasoline performance and improve air quality by lowering vehicle emissions. Primarily because of product slate diversity, DOE's Coal Liquefaction R\&D Program continues to investigate both direct and indirect methods of producing liquid fuels from coal.

The average daily consumption of petroleum products in this country is about 17 million barrels per day. Almost half of this petroleum is now imported, and about two-thirds of the total petroleum consumed is used for transportation fuels. The continuing availability of these liquid fuels is very important to the energy supply situation and economy in the United States. Since the early 1970s imports of petroleum have periodically been jeopardized by world wide political uncertainties. For this reason, DOE has continually emphasized the importance of R\&D for developing alternative sources of liquid fuels that would be suitable for use as transportation fuels. Technology for producing liquid fuels from coal has been available since the 1930s, and coal is the United States' most abundant energy supply scurce. Therefore, much of the R\&D work performed by DOE has centered on coal-derived alternative fuels. 


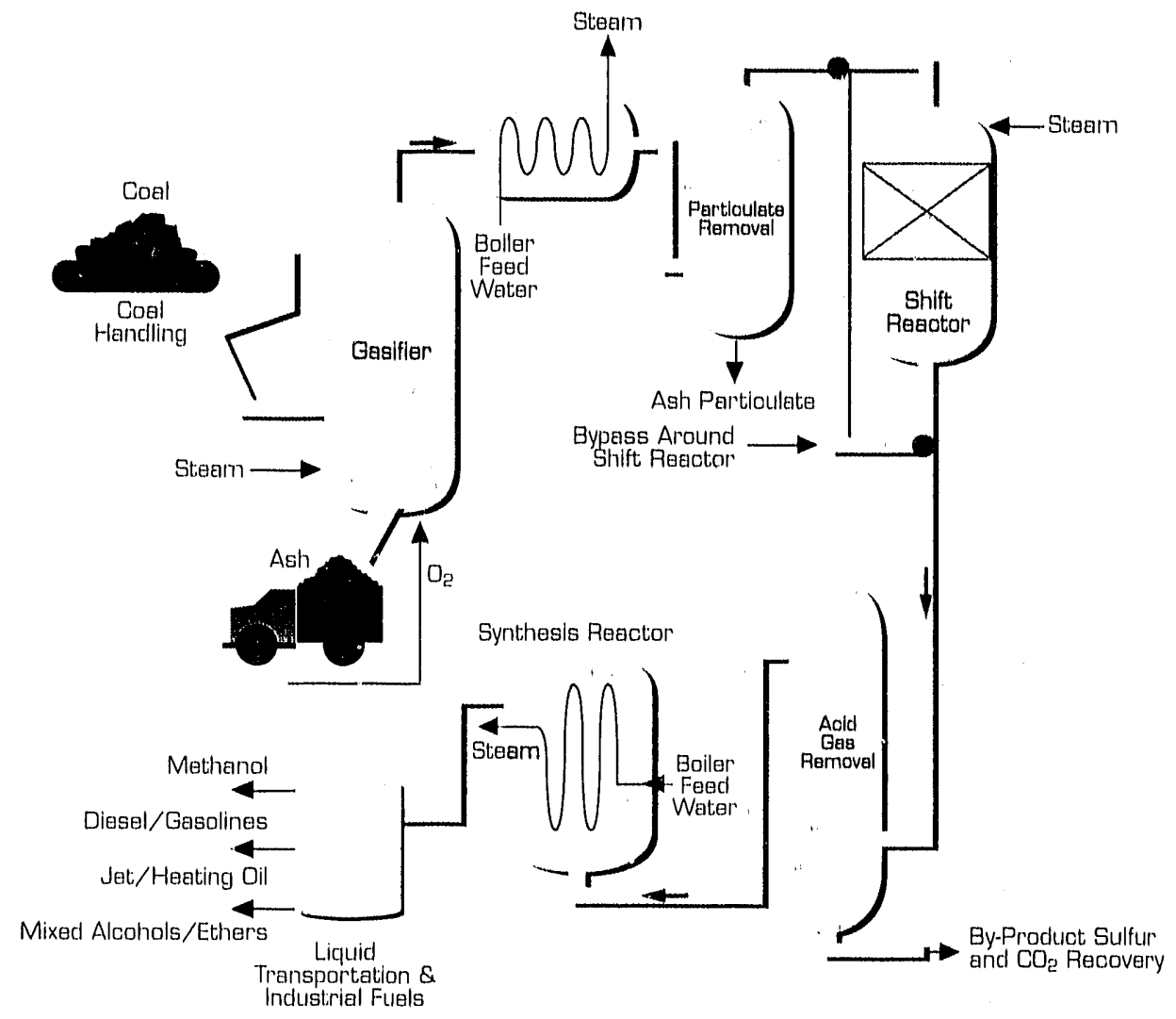

Figure 1. Indirect liquefaction of coal.

\section{Indirect Liquefaction Process Description}

I

indirect liquefaction (seo Figure 1), coal is fed to a gasilier, where il is partially burned at high temperatures under moderate pressures in the presence of oxygen and steam. This partial combustion of the coal generates a gas consisting mainly of carbon monoxide (CO) and hydrogen $\left(\mathrm{H}_{2}\right)$.

This gas mixture is commonly reforred to as "synthesis" gas. In a second step, these gases are cooled and cleaned of particulates. In conventional indirect liquefaction processes, the gases are next sent to a shift reactor in which the $\mathrm{H}_{2} / \mathrm{CO}$ ralio is adjusted to that of the final desired liquid fuel. In advanced indirect liquefaction processes, the shift reacior can be eliminated, thereby considerably reducing production costs, as discussed below. After being cleaned of impurities (e.g., carbon dioxide and hydrogen sulfide), the synthesis gas is sent to a synthesis reactor and converted to liquid products. The products obtained from the process depend on the temperature, pressure, and calalyst in the synthesis reactor as well as the design of the reactor. Typical products include hydrocarbons (e.g., diesel fuel, jel fuel and paraffin wax) and oxygenates (compounds that contain oxygen atoms), such as methanol, higher alcohols, or ethers. Oxygenates may be used as transportation fuels or additives that make gasoline burn more cleanly. Il' specification-grade fuels or marketable chemicals are desired, the mixture of pruducts must be separated.

\section{History of Indirect Liquefaction}

The conversion of synthosis gas to hydrocarbons-the basis of the indirect liquelaction process-was fïrst demonstraled in 


\begin{tabular}{|c|c|c|c|c|c|}
\hline Configurațion & \multicolumn{2}{|c|}{ Sasol } & Advano & Gasifier & $\begin{array}{l}\text { Advanced Gasifier } \\
+ \text { Advanced Reactor }\end{array}$ \\
\hline Gasifler & Lurgi & Lurgl & Shell & Shell & Shell' \\
\hline F-T Reactor & $\begin{array}{l}\text { Fluid } \\
\text { Bed }\end{array}$ & $\begin{array}{l}\text { Fixed } \\
\text { Bed }\end{array}$ & $\begin{array}{l}\text { Fluid } \\
\text { Bed }\end{array}$ & $\begin{array}{l}\text { Fixed } \\
\text { Bed }\end{array}$ & $\begin{array}{l}\text { Slurry } \\
\text { Phase }\end{array}$ \\
\hline $\begin{array}{l}\text { Dverall Thermal } \\
\text { Efficiency, } \%\end{array}$ & 44 & 44 & 55 & 53 & 59 \\
\hline $\begin{array}{l}\text { Required Product } \\
\text { Selling Price, } \\
\$ / \text { barrel }\end{array}$ & 59 & 55 & 51 & 48 & 42 \\
\hline
\end{tabular}

Table 1. Improvements in indirect coal liquefaction - estimates based on using Wyoming subbituminous coal.

Gormany in 1902 by Sabalior and Senderens. Using a nickol calalyst, they showod that CO could bo hydrogenated to produce othylene. Soon after, scientists in Germany demonstrated the conversion of synthesis gas to hydrocatrons and oxygenates ovor a cobalt calalyst al high prossures. In tho 1920s, Franz Fischer and Hans Tropsch usod an iron calalyst al normal prossuro to produce mainly oxygonatod compounds. The process became the basis for much of the following resoarch and is known as FischerT'ropsch (F-T') synlhosis.

After World War Il and with the advent of the Cold War, concoms were raisod regarding the stralegic importance of liquid fuols and tho difficully of assuring accosss 10 Middlo East oil. In response, the Dopartment of the Interior (DOI) proposed a crash program to produco licquid fuols from coal as woll as oil shale. As part of this program, DOl's Buroau of Minos (BOM) constructed a licpuefacion facility in Louisiana, Missouri, using an Army surplus ammoniasynlhesis plant as the silo for both direct liquefaction and F-T indiresal liquofaction unils. 'Those two units woro designed to produce 200 and 100 barrols per day, respecitivoly, of liquid products. Howevor, with abundanl supplios of very-low-pricod Middllo Fiasl crurbe oil, tho Unilod Stales soon lost inlerest in producing liquid fuols from coal, and tho planl was alosed in 1953.
Full-scale commorcial production using indirect liquefaction of coal has occurred only in the Republic of Soulh Alrict. In 1955, a South Africian firm, Sasol, Led., further dovoloped P-T tochnology by constructing and commissioning an indiroct liquofaction plant, known as Sasol 1 . This facility is still operating loday and uses an iron-based calalyst. Research al Sasol continued for the next 20 yoars and resulted in numerous improvements to the operation. After the oil ombargo in 1973 and under increasing oconomic isolation rosulting from its aparthoid policios, tho Soulh African governmont subsidized Sasol's construction of two new' plants-Sasol II and III. Those two plants were commissioned in 1980 and 1983, respectively. 'The combined annual production capacity of all throe Sasol facilitios is 50 million barrels of liquid producis. 'T'hoir combined outpul provides much of South Africa's licquid transportation fuels.

Coal is not tho only feodslock for indiroct liquolaction processes. Natural gas can bo roacilod wilh stoam to ylold synthosis gats, which can bo subsequently converted lo liquid producits, In the ourly 1950s, an F'I' plant oporaling on nalural gas was built by tho Ci.lhange Hydrocol Company in Brownsvillo, 'T'oxas. This lacility omployed reactor' lechnology dovolopod by Hydrocarbon Resoarchi, Inci, a company thal conlinues lo play a significant rolo 
In our on-going R\&D program. This plant only operated for a brief lime becauso of increased U.S. demand for natural gas and low prices for petroleum fuels. More recontly, industry has shown increased intorest in using indirect liquefaction processes based on natural gas. Throughout the world, there exist abundant supplies of low-cost natural gas that exceed the demands of local markets. Indirect liquefaction tochnology offers the means of converting these remote natural gas resources to liquid products that can be economically transported to meet international market needs. For example, the Mobil Corporation has constructed a commercial indirect liquefaction plant in New Zealand. This plant, which began operations in 1985, has a total product capacity of 14,500 barrels of gasoline per day. Natural gas is first converted to synthesis gas, which is subsequently converted to methanol and then gasoline. Technology to convert synthesis gas to methanol has long been available. What made the New Zealand plant possible was Mobil's development in the 1970s of a process to convert methanol to gasoline using a new catalyst. Recognizing that this approach is also appropriate for coal-based processes, a portion of Mobil's overall development effort was funded by the Department of Energy.

\section{Goals of the DOE Indirect Coal Liquefaction Program}

$\mathrm{T}$ The Coal Liquefaction R\&D Program, as a whole, is directed at meeting National Energy Stralegy goals to "reduce the cost, investment risks, and environmental impacts of producing liquid fuols from coal." Although F-'T synthesis for indirect liquefaction has been demonstrated in large commercial-scale plants in Soulh Alrica, the technology used there is inelficient, and the estimated product cost is not low onough to be commercially compolitive with petroleum products wilhoul the aid of government subsidies, If a similar plant, including tho Lurgi gasiliors used in Sasol II and III, were built in the Uniled Stales, the required selling price of the product would be about $\$ 55$ to $\$ 59$ por barrel (see trable 1), and the overall thermal efflciency of the process would be low, uboul $44 \%$. Therefore, one of the major gouls of the Indirect Liquelaction R\&D Program is to find and develop procoss improvements that will lower the cost of liquid products to a level that is competitive with transportation fuels derived from petroleum. Engineering analysos indicale that a goal of producing liquid producis for $\$ 30$ or less per barrel (crudo ofl equivalent) is not unrealistic and may be reached in tho near fulure.

Inherent to reaching this cost goal is a major improvement in the thermal ofliciency of indirect liquefaction. Such an effictency improvement would not only reduce local onvironmental impacts associated with liquids production but would also yield significantly lower emissions of carbon dioxide, which has been associaled with global climate chenge. Another important environmental objective of the indirect liquefaction program is the production of alternate transportation fuels that show superior emissions performance upon combustion. For example, the diesel fuol produced via F-T' synlhesis has been shown to substantially reduce hydrocarbon, $\mathrm{CO}$, and particulate omissions, as compared with conventional diesol oil. Our work in dovoloping indirect liquefaction procosses for production of oxygenates is very much molivated by their ability to reduco pollulant emissions.

\section{Oxygenates}

$\mathrm{T}$ alcohols or other's. As additives in transportation fuels, particularly gasoline, these matorials increaso octane ratings and reduce pollulant emissions. 'The use of oxygenales in transportation fuols is likoly lo incroaso as rofinor's and automobilo manufacturers struggle 10 achiove the reduced vohicie omissions goals required by tho 1990 amondmonts to tho Clean Air Act. Current potroloum-basod commorcial lechonologies for oxygenales yiold noarly puros compounds al costs significantly higher than petroloum, In addition, use of largo amounts of a 


\section{Composition \\ Dry, Vol\%}

$\begin{array}{lcc}\mathrm{H}_{2} & 30 & 50 \\ \mathrm{CO} & 66 & 25 \\ \mathrm{CO}_{2} & 3 & 10 \\ \mathrm{CH}_{4}+\text { Higher Hydrocarbons } & - & 15 \\ \text { Inerts } & 1 & 2 \\ \mathrm{H}_{2} / \mathrm{CO} \text { Molecular (Volume) Ratio } & 0.45 & 61 \\ \text { Net Efficiency } & 78-80 & \\ \text { to Synthesis Gas, \% } & & \end{array}$

Table 2. Composition of synthesis gas from Shell and Lurgi gasifiers operating on Western U.S. coals. Net efficiency includes thermal losses in reforming methane to synthesis gas.

single compound in gasoline skews the performance characteristics of the fuel and can result in operating difficulties in internal combustion engines. Indirect liquelaction can produce mixtures of alcohols and/or ethers, which may be less expensive than pure compounds and which may be used in higher concentrations in the fuel without sacrificing the operating efficiency of the vehicle. For these reasons, the oxygenates research being conducted under the Indirect Coal Liquefaction Program is focused on unique new roules 10 fuel components that may be more economical and more technically desirable than those available with potroleum-based technology.

Some of the current research work on oxygenates was reported on at the Liquefaction Contractors' Reviow Meoting held in Piltsburgh, Pennsylvania, September 3-5, 1991: "Synthesis of Octane Enhancors During Slurry-Phase Fischer-Tropsch," "High Octane Ether trum Synthesis Gas Derived Alcohols," and "Development and Demonstration of a One-Step Slurry-Phase Process for the Co-Production of Dimethyl Ether and Methanol." In a lator issue, we will discuss our R\&D activities dirocted at the production of oxgonatorl transportation fuels.

\section{DOE Research in Fischer-Tropsch Technology}

\begin{abstract}
A major advance in our ability to produce liquid fuels using indirect coal liquelaction has already occurred. New, more efficient coal gasifiers for synthesis gas production havo beon doveloped and demonstrated. 'These include tho Dow, Texaco, and Shell gasifiers. The availability of these improved gasifiers plays a major part in improving procoss oconomics because up $1080 \%$ of the total cost of an indirect liquefaction procoss is involved in preparing synthesis gas. A comparison of the thermal efficiency of tho Shell gasifier with that of the Lurgl gasilior used al Sasol is given in l'ablo 2. Besides being moro thormally efficient, these advanced gasifiors roguire substantially loss ovorall plant capital investment than do the largh gastfiors. As shown in 'lablo 1, product costs f'rom li-']' synthesis are reducod from $\$ 55-59$ to $\$ 48-51$ per barrel whon Largi gasifiers are roplaced with highofficioncy gasifiers, in this case the Sholl, while using the samo fluid-bod or fixed-bed lype roactors found in tho siasol plants.
\end{abstract}

All three of the mores efficient, antvanced gasifiens montioned above (Dow, l'exalco, sholl) are 
operaling at or near commercial scale in facilities in the United States and Europe. The newer gastliers, however, have an inherent drawback when used as the first step for indirect coal liquefaction: Typically (see Table 2), they produce a gas with a lower proportion of hydrogen than the gas from a Lutrgi gasifier. Indireal liquefaction synthesis reaclors available today are unable to accept a low $\mathrm{H}_{2}$-to-CO gas. This means that the gas composition must be modilied (before F-T synthesis) by additional and expensive calalytic processing in the shift reactor. This problem also raises an opportunity for R\&D that can significantly lower total production costs; namely, the development of an advanced synthesis reactor that can use the low $\mathrm{H}_{2}$-lo-CO synthesis gas directly.

Earlier DOE-sponsored work in methanol synthesis technology showed that slurry-phase calalytic reactors could be effectively used to convert low hydrogen synthesis gas into liquid fuols. Systoms engineoring analyses performed for DOE havo shown that development of slurry- phase reacitor lechnology for F-T synthesis would allow the catalytic shift reactor to be completely eliminated (see Figure 1), improve overall process thermal efficiency and yield lower cost transportation fuels, as summertzed in the right-most column in Table 1. Therefore, the DOE R\&D program for Fischer-Tropsch indirect liquefaction is focused primarily on the development of slurry-phase reactor lechnology.

There are three main elements to this elfort:

- Development of the reactor itself

- Development of calalyst-wax separation lechnology

- Development of effective catalysts for use In slurry-phase reactors

To understand the rationale for the research efforts in these areas, it is first necessary to understand the slurry-phase reactor and its unique characteristics and to contrast those to the more conventional fixed-bed reactor (see Figure 2).

Figure 2. Reactors used for Fischer-Tropsch synthesis (schematic diagram).

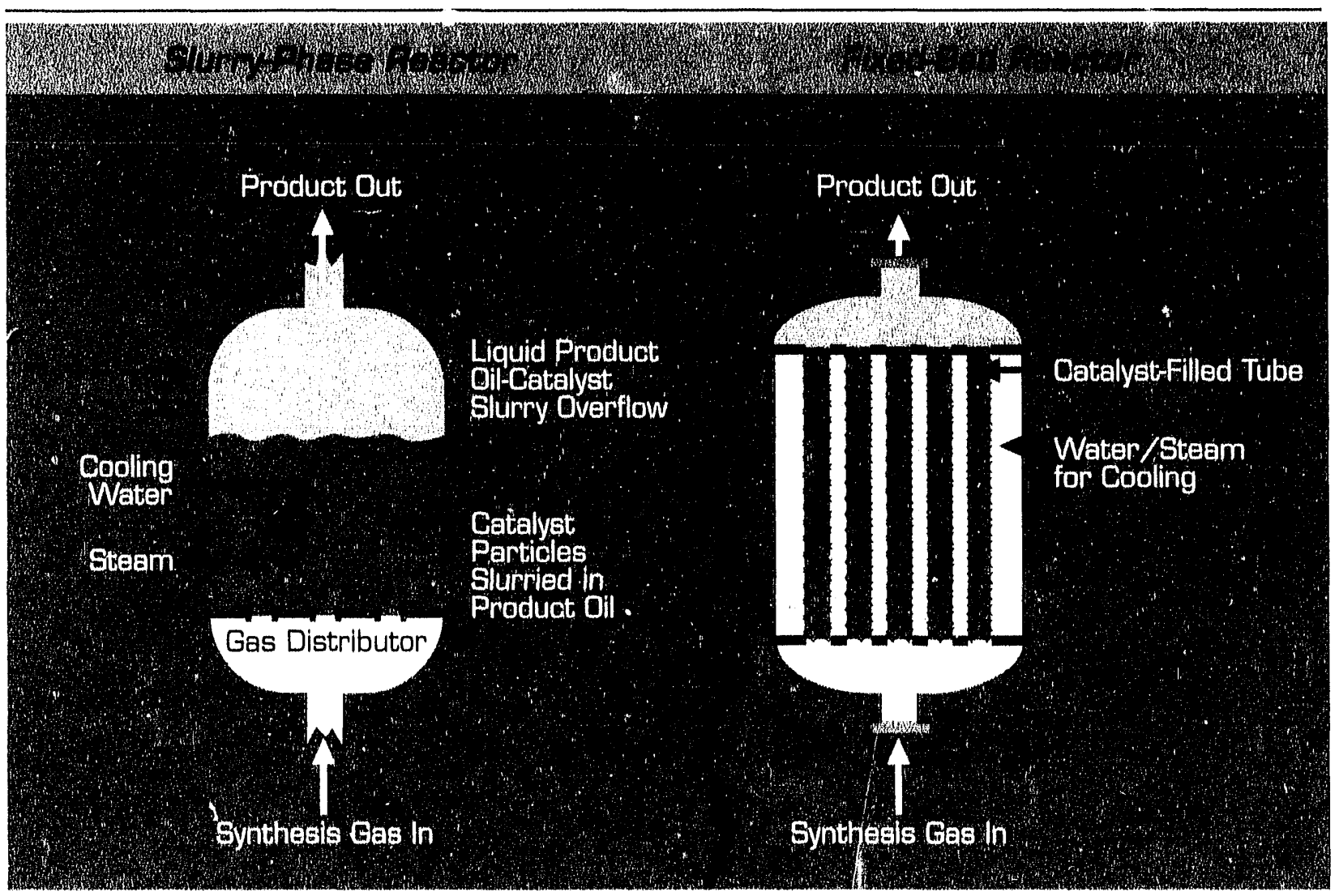




\section{Advanced Reactors}

The conversion of synthesis gan fo lifuldes is an axolhermic reacitlon (i.o., considerablo hent is givon ofl'), and this heat must bo romovod, In a lypical lixod-bod synthosis reacitor, tho catalyst is packod into about 10,000 one-1nch lubess, and the synthesis gas !s sent through this array of lubos. The tubes are w'aler-cooled, and much of tho heat given off by the roncitor is captured as procoss steam. Howover, hoal transfor within tho packed lubes is poor, and if a low $\mathrm{H}_{2}-10-\mathrm{CO}$ synlhosis gas wore used, carbon would be deposited on the calalyst surfacos, reatulting in sovere calalyst dencitivation and loss of operability.

In contrast lo tho lixod-bod reactor, tho slurryphase reacitor is relativoly simplo. Basically, a finely divided calalyst is suspended in a liquid. For fr-T' synthosis, this licuid is a waxy portion of the product. Tho resactant gases are bubblod through the catalyst slurry and roact on tho surface of the calalyst to produce the desirod product. 'The use of finely divided calalysts onsures high rates of reaction that result in a large amount of product per unit of reactor volume per unit of time. 'The presencice of the liquid and the furbulence causod by tho gas flow allow the offoctive removal of heat from the surface of the calalyst. 'Therefore, highor rales of reaction and grouler conversion can be achioved.

In the slurry-phase reactor, lhe gas flow keops the calalyst slurry well mixed. Tho heal given oft by the reaction is recovored as stoum through a hoal exchangor ombeded in tho reastor volumo. Moreover, the total heat exchanger tube area is only a small fraction of the lube area of a fixedbod reactor for F't' syuthesis. 'This oxcellont ability to remove the heal givon off hy the exolhermic reaction provonts carbon from boing doposited on calalyst surlacos, theroloy roducing calalysa doactivalion whon low $\mathrm{H}_{2}-(\mathrm{l})-\mathrm{C}(\mathrm{C})$ syonthesis gas is used. Thoso aro the advantages of slurry-phase roactors.

Tho major uncertainly about using slurry-phaso reactors for fi-'] symbersis involves fluid flow and hoat transfor chatracteristics in the roactor. Dolis's slury-phase reactor resentreh offort will obtain hydrodynamics, hoal transfor, and mass
Iranstor clala nooded lo proporly design slurryphaso rouclors. 'l'his will bo accomplishod by issulang a sollcilation for gathoring oporalional dala that covers a rango of axporimonlal reatitor stzos. In addition, a mothodology for dosigning a slurry-phase roacilor will bo devoloped, and a consistent set of correlations for all dosign paramolors will bo produced.

Oplimization of slurry-phuse roaclor operalion may reculute a number of process modificiations, includling changos in (1) roactor conllguration lo improvo mixing, heal lransfer, or vapor-alicuid soparalion of tho products; (2) catalyst particile sizo distribulton or surface proporties to reducio sollling or lo incrouse the concentration of calalyst within the reactory and (3) the liquid compostion in tho roactor to allow for higher gas volocity or holler hoal transfor.

\section{Catalyst/Wax Separation}

Slurry-phase roaclors used for l'-'l' synthosis produce product wax inside the reacitor, 'T'o maintain the proper slurry lovel inside the reactor, the wax must be continuously romoved. At the samo timo, to provont calalyst loss, an officiont mothod for soparaling tho culalyst from the wax aftor romoval from tho roactor is ossentlal. 'l'he wax can be roadily prociessed (hydrocracked) inlo promium-quality diosel fuel if'it is rehatively froe from catalyst. 'Tho diessol fuol producod has boen shown lo substantially reduce hydrocarbon, $\mathrm{CO}$, and particulate engino emissions comparod with conventional diessel fuel.

In orly fiscal year 1992, DOL will issuo a solicitation for dovelopment of now or improved lochnologies to soparalo the calalyst from the product wax. 'lhe solicitation will cover two phases: (1) basic laboralory rosenreh to dovelop) tho tochnology, domonstrate performance, and obtain sufficiont dala lo porform an initial dosign and cost ostimato and (2) comstruction of a unit and porformance of additiomal enginoering evaluations in an intogralod bonch-scallo unit.

\section{Catalysts}

Catalyse resourch is primarily comeormed with doveloping calalysts for slurry-phase roustors 
Matal

Relative Cost

Iron

Cobalt

Nickel

Ruthenium

Rhodium

Table 3. Relative cost of catelyst metals

that have on hanced actlvily, Improved selectivity (i.e., ability lo produco tho desired product), good stability (i.e. long lifo), and loloranco for polsons that could deactivato the calalyst. Numerous motals have been ovalualed as catalysts for F-'T' synthosis. Table 3 displays the relativo cost of theso melals.

As shown, tron is by far the least expensivo motal for uso as a catalyst. The use of coball, howover, may be justilied because of its highor activity and improved selectivily to mako hydrocerbons.

Although the cost of nickel is aboul the samo as coball, it produces loo much mothano to warrant further investigation. Finally, tho high cost of ruthonium and rhodium and thoir lack of availability are obstacies for their commorcial uso.

T'able 4 shows tho larger portormanco criteria that have been established for ovalualing and comparing calalysts. Synthesis gas conversion should bo high, and soloctivily lo light hydrocarbon gases should bo low to eliminate the need to reform tho gases $10 \mathrm{H}_{2}$ and $\mathrm{CO}$, which
Is costly and would dociruase offledency. High calalys acillvily and calalyst loadlings aro requilod in slurry-phase rouciors for maximum productlvily, and lhis will resull in reducod copilal cossts.

Thore aro soveral types of tron calalysts bul tho mosl aclive are those mandafadured by precipilation ol tron salss. 'Thereloro, tho Indirocil Licfuofaction Program has focisud on proparation and use of precipllatod tron callalysts. Tho slops recpuled to prepare these cialalysis aro listod in Tablo 5. T'ho point of this lablo is that oesch of tho oight slops in tho procoss has sovoril procoss variables that can be controlled. Each variablo can have a major impact on the properllos of tho calalyst (activily, stabilily, solocitivily, and slurry bohavior). Tho rolo of aach of theso variables musl bo understood to produce the best possible calalyst.

Two major conlracts are currenlly in place for calalyst dovelopment-ono wilh the Universily of Konlucky and ils loammulo Unilod Calalyst, Inc., and tho other with UOP, Inc. 'Two calalysts from the UOP contrad wore recently ovaluatod in a slurry-phase reaclor for exlonded porịods of time. Both calalysts were extromoly stablothe lin'st was lested for over 2,000 hours; tho socond was moro than I wico as activo and almost achieved all of the performance critoria listed in Tablo 4. Becauso of their highor acilivity, DOE also plans to develop coball-basod calalysis. A solicilation was issued in Fiscal Yoar 1991, and awards will be made in early Fiscal Yoar 1992.

Table 4. Desired performance criteria for slurry-phase reactor catalysts.

- High catalyst activity (i.e., high conversion-about 88\%—of synthesis gas to products).

- Good catalyst stability and tolerance for poisons that can deactivate a catalyst$\leq 1 \%$ deactivation of the catalyst per week for 2 weeks.

- High selectivity to desired products and $\leq 4 \%$ light hydrocarbon gases (methane and ethane) in products.

- Ability to use low (0.5 to 1.0) hydrogen feed gas from new, more efficient gasifiers.

- Ability to operate slurry reactor with high loadings ( $\geq 20 \%$ ) of solid catalyst in slurry phase. 
1. Preciritate an Iron oxide/oxyhydroxide gel containing a oopper promoter.

2. Filter to separate the precipltate from the solution.

3. Dry the filter oake.

4. Crush the filter cake to the required perticle size.

5. Impregnate the powdered filter cake with a potasslum-based promoter.

6. Calcine the material promoted with potasslum.

7. Grind and size to produce the final catalyst particle size (between 10 and 50 mlorons).

8. Establish pretreatment reaction conditions for attaining desired catalytio activity and selectivity.

Table 5. Steps for preparing a precipitated iron cetalyst

\section{Major Research Facilities}

$\mathrm{T}_{w}$ dovolopment and onginoor'ing offorts of tho inclireset licfuofaction program, laboralory results will first bo lostod undor inlograled operating

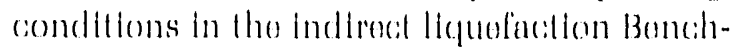
Scalo Unil (BSU), now under design. Procossess that show favorablo bohinical and oconomic: potential will be furthor lested at the Altornates Funds Dovolopmont Unit on a larger scito that will obtain porfripmanco dala rolovenul to industry.

\section{Indirect Liquefaction Bench-Scale Unit}

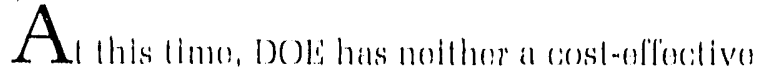
BSill availablo lo collocit the noudod slurery-phases

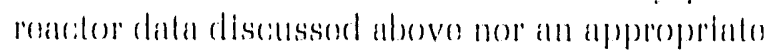
anit lo lest tho catalyst-wax soparation

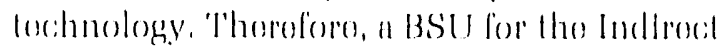

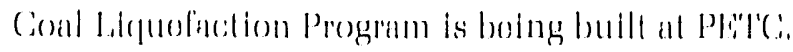
'Tho M.W. Kollogg Compuny is dosigning and installing tho facillity: comploution is schordulod for frall logis.
\end{abstract}

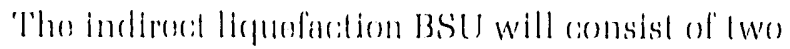

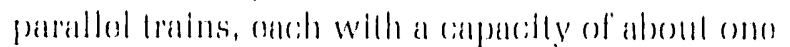

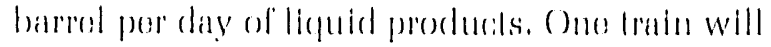
bo dediandod to the syonthesis of oxygomilod

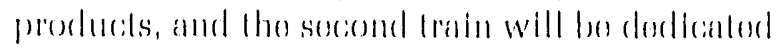

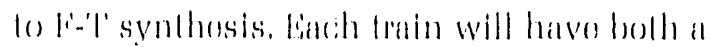

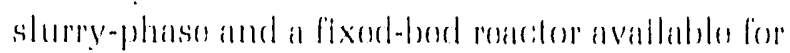

oporatlon. 'I'ho BSU will bo ablo lo oporalo over" a wider rango of procoss comdillons. Tho somposillon of tho food gins (inciluding imporillos such as

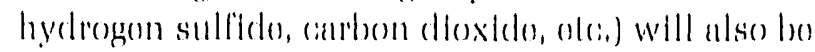
variablo over a wido rango to slmulato any gnatlion producit composition.

Tho Indirocel licfuofuctlon BSO will bo usod lo dovolop slurry rousclor design information, provo oporabillily of the callalyst-was soparalion unit, and lest tho bost calulyst or conlalysts dovolopod

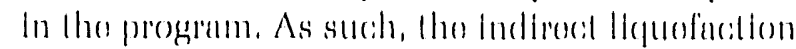
BSist a will sorvo as tho programs's koy facillily for locihnology dovelopment, ovalualton and lansifor, forming a briclgo bolwom laboratory work on now

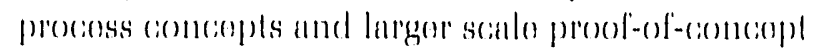
losting. 'l'ho intograted oporating data dovolopoed

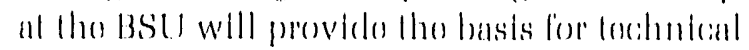

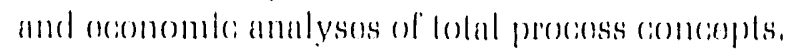

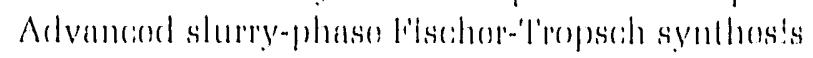
anchonologites that pass mustor will bo moverd lo

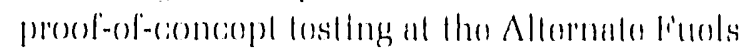
I)ovelopmonul Intit.

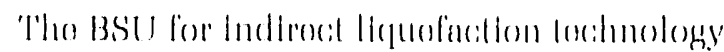

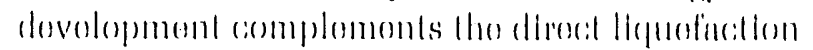

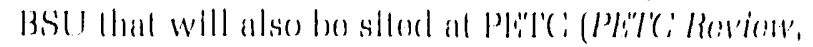
March 1091). In addillon losupporthng program-

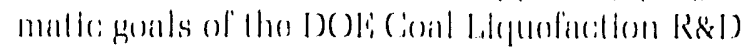

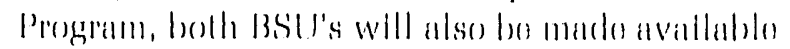
for comducthe industry-proprlotary R\&D), By

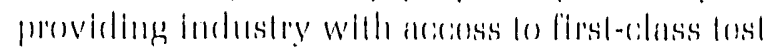

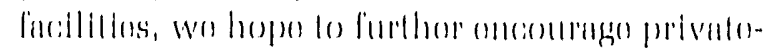

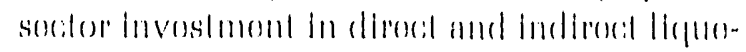

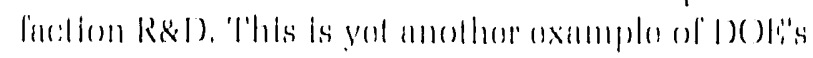




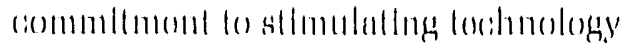

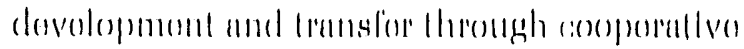
alforlis will hodustry.

\section{Alternate Fuels Development Unit}

$T_{\text {hu }}$

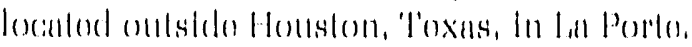

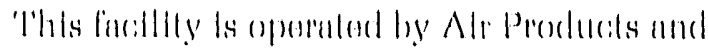

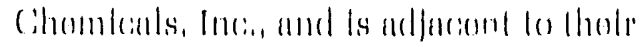

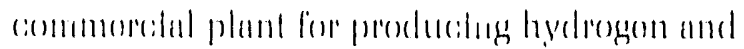

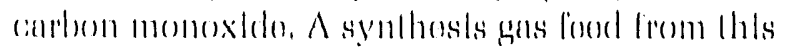

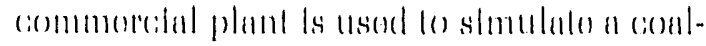

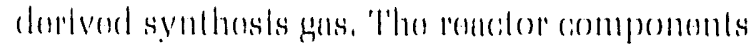

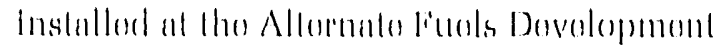

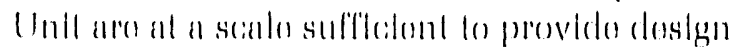

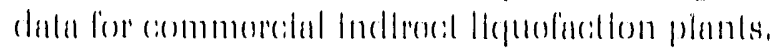

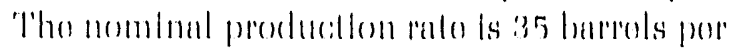

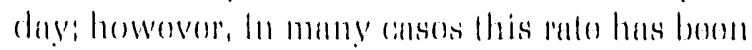

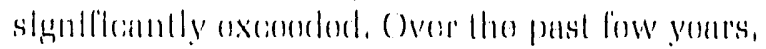

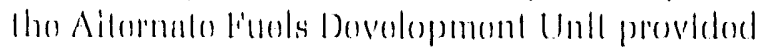

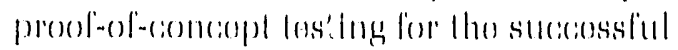

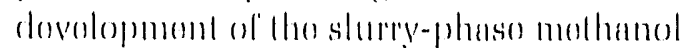

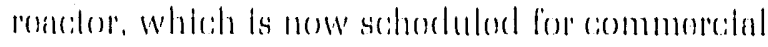

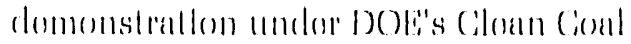

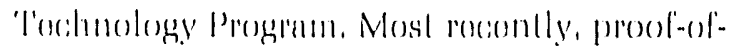

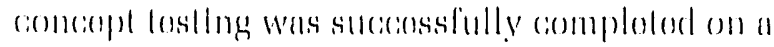
now proconse for oflelolontly convorling syonlhosis

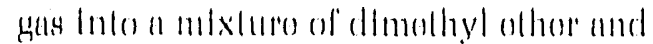

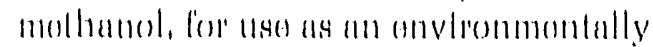

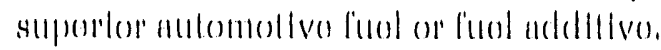

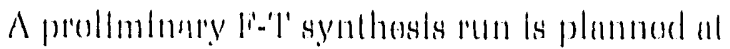

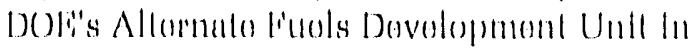

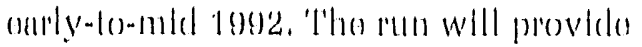

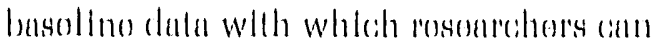

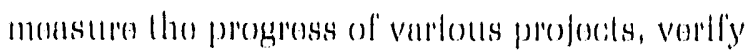

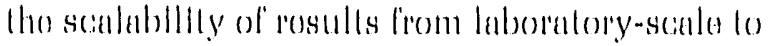

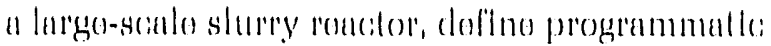
ressourch nouds, and produceo producis for uso la

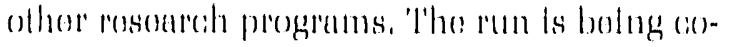
sponsored by sovoral industral organlzallons.

\section{Future Liquefaction Topics}

W is a koy componont ol tha Dopentmonl's ovarall

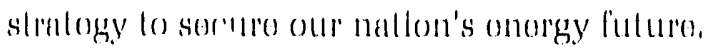

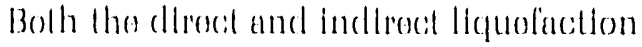
programs aro focused on producing Iransportalion fuols al lowor cosis and roducool onvironmonlal lompacis, In fulure lissuos of tho Pl'l'C Roviow, wo will discuss our R\&D olforls in sxygonalos and in advancesel concopts lo Inlograbo licyualacition with lochanology for olocitrie powor gonoraliom.

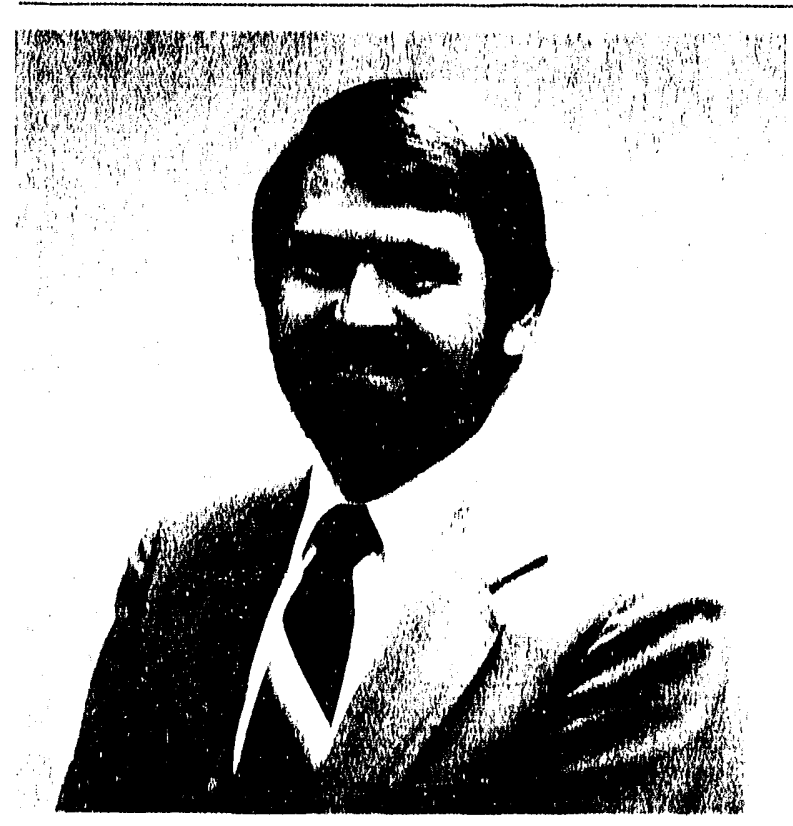

Gary J. Stiegel is Progrem Coordinalor for

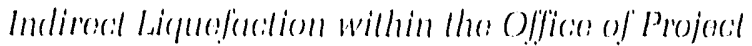

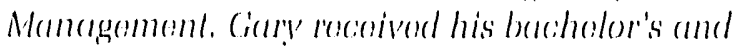
mostar's degroes in chemical onginenering and and MBSA from the L'niversily of Pillshurgh. Before: joining Pli"l'ci in 1976, ho wess amployed by lonion

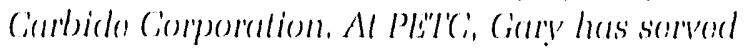

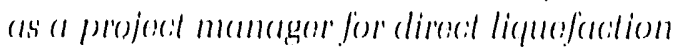

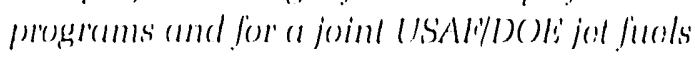

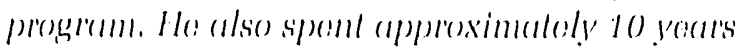

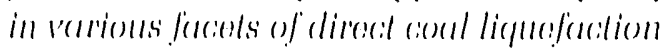

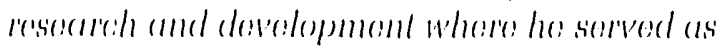

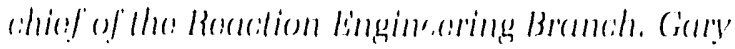
is a registered profossisiorial ongineser in

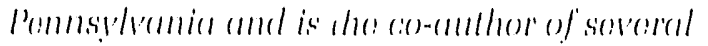

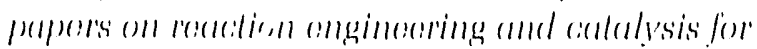

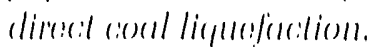



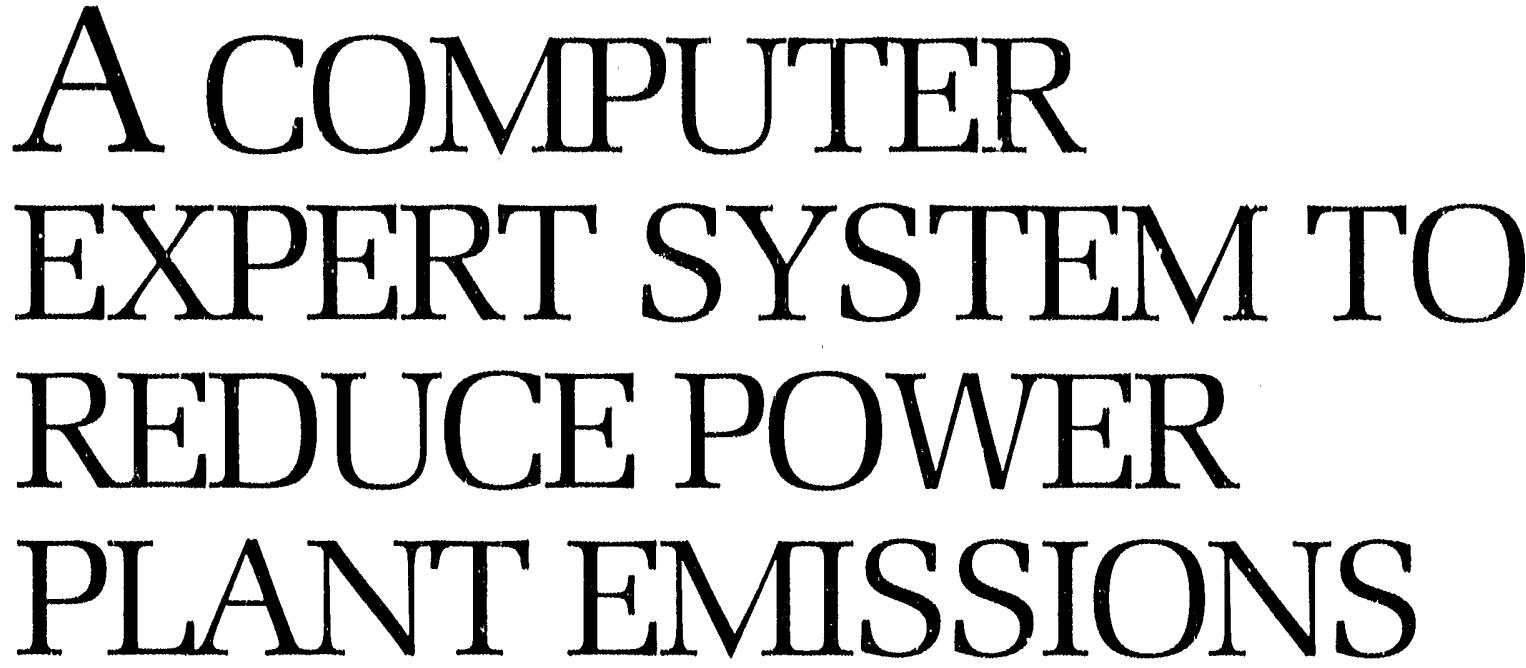

Tho Coal Quality Expert computer system is designed to give utilities a new and powerfal lool that will quickly and oconomically predict the total ciost impact of coal quality on boiler performance, maintenance, operalional costs, and emissions. Integrating more than 20 computer models into ono workstation, the Coal Quality Expert will evaluate numerous options, as spexified by the user, to determine the least expensive emission control stralegy for a given plant. The U.S. Department of Energy (DOE) selected this $\$ 17.4$ million project in Round 1 of tho Clean Coal Technology Program. This project is performed joinlly by CQ. Inc: (a wholly owned subsidiary of the Liles:Lric: Power Research Institute |EPRI/ located in Homer City, Pennsylvanial); ABB-Combustion Eingineoring in Windsor, Connesticuli and olhors.

$\mathrm{T}_{1}$

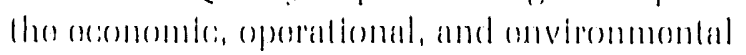

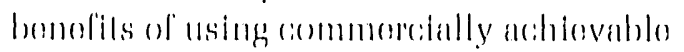

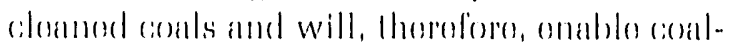

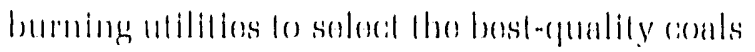

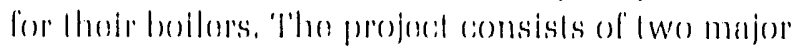
anstivilios: (1) losting and dala gathoring, which

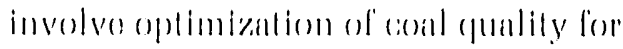

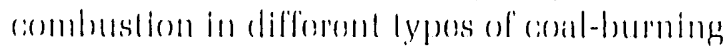
ulilily boilors and (2) dovolopoing and oxpond

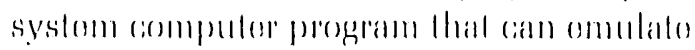

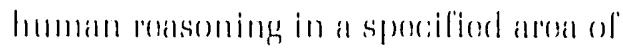
knowlorlgor.

A major forens of this projocal is oxtomsiva dala-

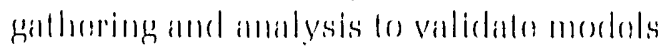

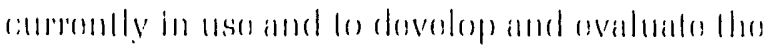

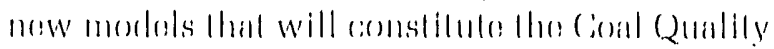

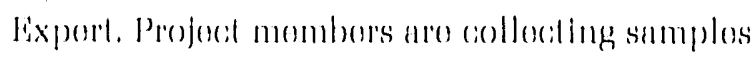

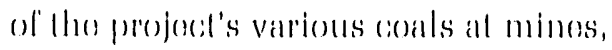
commonrsial siloaning phants, and at tho project's six host powor plants. A lotal of 26 couls aro

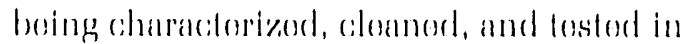
bonchlo-ame pilol-scalo combustion chambons to

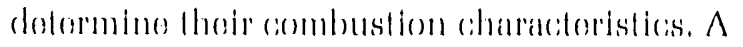

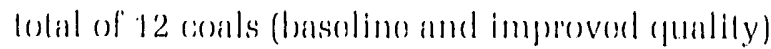

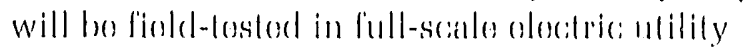
boilors al six silos. 'l'hrough tosting all all lhoor scalles (boureh through full), tho projocet is ablo lo isolalo koy vardablos and dolominimo how hooso variablos alfoul lull-scalo oporalions.

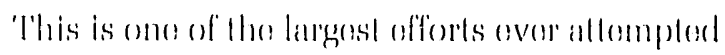

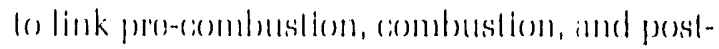

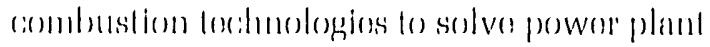
amission probloms. (ovor 20 (ompramios fiom 
around the country, including software developers, lesting laboratories, and utilities, will participate in this project.

Figure 1 shows the major components of the Coal Quality Expert System. All of these models are integrated into a single tool to enable planmers and engineers to examine the cost and effects of coal quality on each facot of power generation from the mine to the stack. The Coal Quality Expert System will guide users to the appropriate components of the system with a series of questions or specific menu options. Users may only need to use one or two components for some analyses; other efforts may require the integration of many model results.

The foundation for the Coal Quality Expert is EPRI's Coal Quality Impact Model (CQIM). This model assesses the impacts of coal quality on plant performance and operaling costs. Already used by 75 ulilities, tho CQIM fealures dolailed equipment modules for all systems that are directly affected by coal quality. All performance factors are translaled inlo specific costs, allowing direct comparisons of alternative coal supplies. More than 20 olher software models and data bases (including a flue gas desulfurization model, a coal cleaning cost model, a transportation model, and a now plant construction model) will be integrated with CQIM to form the Coal Quality Expert. Within the project, responsibility for soltware development and integration rests with Black and Veatch.

CQ's Homer City Coal Laboratory and the University of North Dakota Energy and Environmental Research Center in Grand Forks are now analyzing the test coals. The ABB

Figure 1. Coal Quality Expert system: Abbreviated schematic.

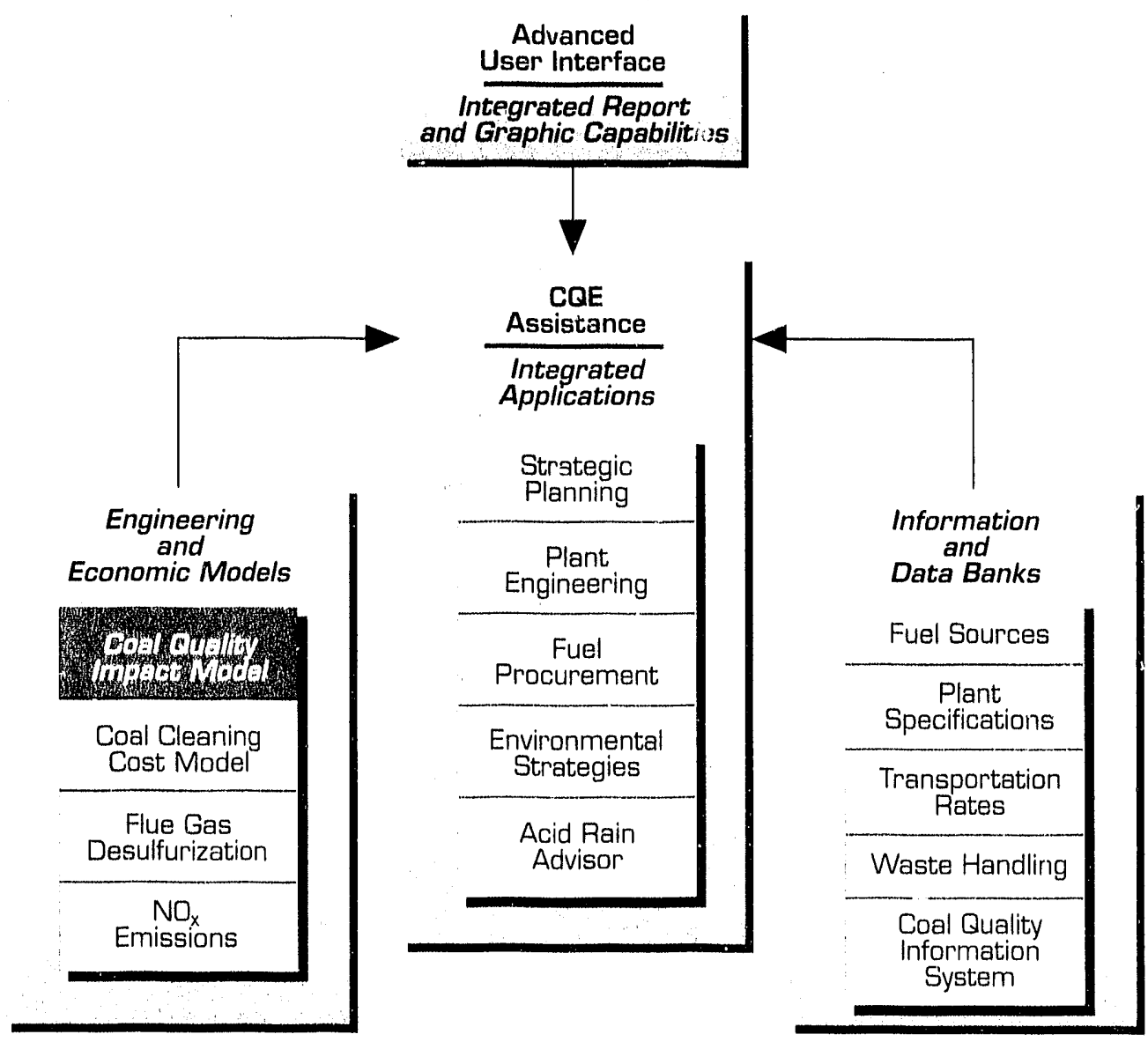




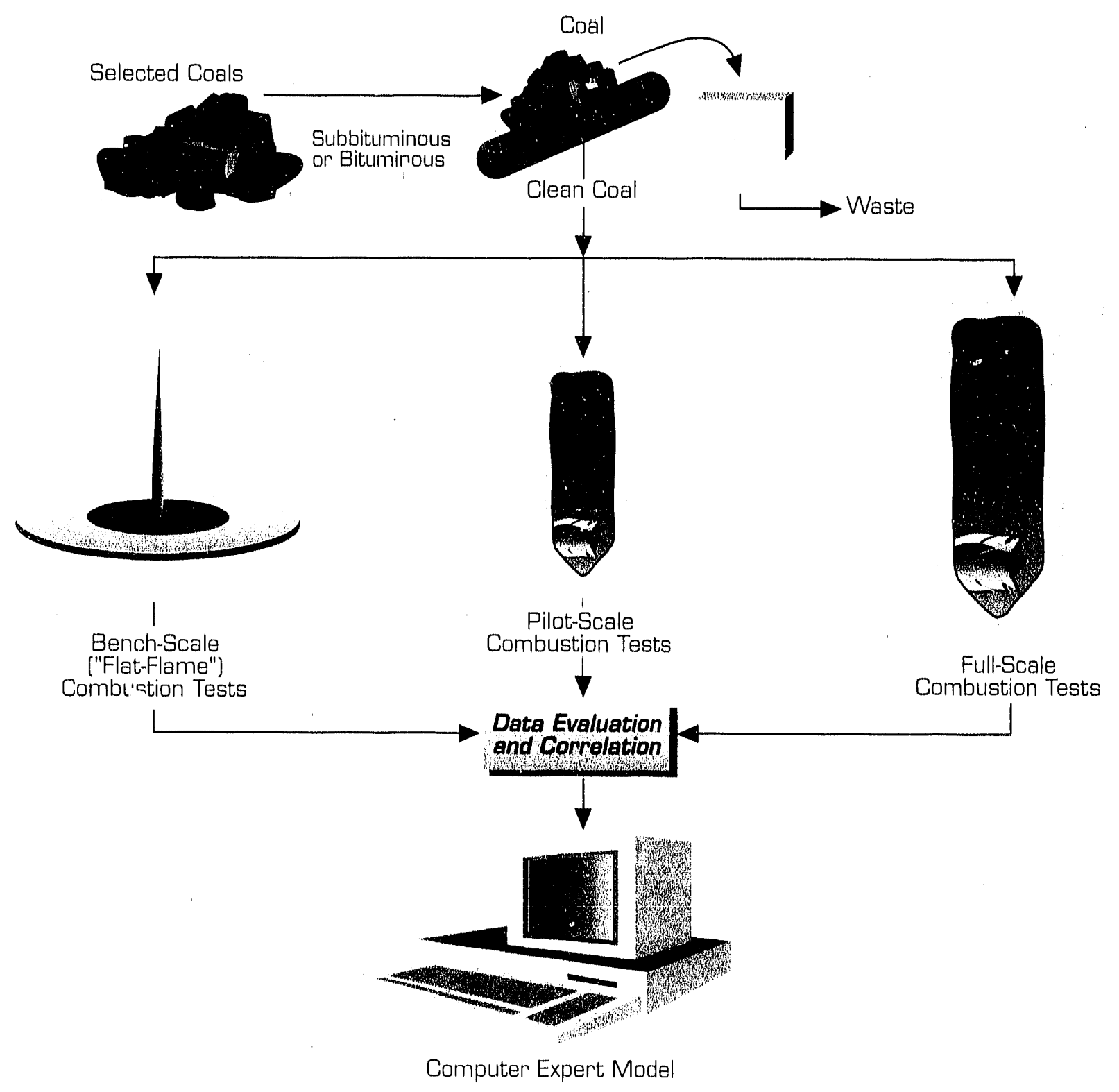

Figure 2. Consi $\overline{n g}$ a data base from test results.

Combustion lingineering's 'Test Facility in Winclsor, Connecilicul; the Babcock \& Wilcox (B\&W) Research Center in Alliance, Ohio; and the University of North Dakola Enerby and Envirommental Researeh Conter are performing the bench-and pilor-scate combustion lests on these coals (see Figure 2).

Six full-scale field lests are being conducted in all major lypes of boilers. lilect ric: Power 'Techonologies (EP'T) of Menlo Park, Cálifornia, will lead a leam of contratelors who will moasure? power plant performanco using the tost coals. Dala from these 30-day test burns will help to determine the impacts of changes in coal qualily (by cleaning, switching, or blending) on plant performance and emissions. 'This lost program is now in progress. The designated planl siles ane:

- Alabama Power Company's Gaston Planl in Wilsonville, Alabama

- Mississippi Power Company's Walson l'ant in Ciulfurn, Mississippi 
- Northern States Power Company's King Planl in Oak P'ark Heights, Minnesota

- Public Service Company of Oklahoma's Northeastern Plant in Oologah, Oklahoma

- Pennsylvania Electric Company/New York State Electric \& Gas Corporation's Homer Cily Plant in Homer City, Pennsylvania

- Duquesne Light Company's Cheswick Plant in Springdale, Ponnsylvania

During field testing, project teams collect coal samples and lake measurements al the pulverizers, the boiler, the fans, the precipitators, and the flue gas ducts. The field test dala collected will be used to corrolate coal characteristics with combustion behavior. The goal is to determine engineering correlations that will accurately predict how a particular coal will burn in a designated unit. This will reduce future needs for full-scale lest burns, which can cost more than $\$ 1$ million each. The fireside advisor software in the Coal Quality Expert will provide guidelines for determining which tests to apply and a step-bystep procedure for conducling test burns to avoid unnecessary, expensive lesting.

The test data generaled will be used to develop) and validate the Coal Quality Expert models that will predict the performance of commercially available cleaned coals with regard to sitospecific total plant performance. The compuler models will provide specific: information on slagging and fouling, precipilator performance, flue gas particulate removal, nitrogen oxides $\left(\mathrm{NO}_{\mathrm{x}}\right)$ formation, sulfur dioxide $\left(\mathrm{SO}_{2}\right)$ emissions, llue gas desulfurization performance, anc. pulverizer woar.
So far, two field lests have been conducted. The flirst was performed between August and December 1990 at Public Service Company of Oklahoma's, Northeastern Station, Unit 4. 'The lest involved two types of coal (Wyoming's Upper Middle and Lower Wyodak seams and Oklahoma's Crowborg soam) normally used at the plant and three different blends of those coals. The purpose of the test was to determine slagging characteristics of the blended coals. Test results indicated that a blend of $90 \%$ Wyoming and $10 \%$ Oklahoma coal showed more superior ash deposition charactoristics than did Wyoming coal alone. The second liold lest was conducted from Ootober 9 to November 10, 1990, at Mississippi Power Company's Watson Plant Unil 4 in Gulfport, Mississippi. The operational impacts of blends of several coals (lllinois No. 2, No, 3, No. 5, and No. 5A; and Western Kentucky No. 11) normally used at the plant wero evaluated to assist in planning fulure coal procurement, as well as lo develop data required for the Coal Quality Expert.

The Coal Quality Expert will predict the effects of a particular coal on each facet of power generation-from the mines to the stack. The expert system will evaluale numerous options (including various qualities of coat, available transportation mothods, and alternative omissions control strategies) to determine the most cost-effective coal and the least expensive omissions control stralegy for a given plant. 'This software will enable power station operators to select the right quality coal to produce the lowest cost electricity and yet romain within emission limils.

During the performance of this project, which is scheduled for completion in February 1994, individual computer models will be completed and made commercially available to industry. The entire Coal Quality Expert system will be commercially available at project completion. For further information about these models, please contact:

Mr. Clark Harrison - CQ, Inc. - 1 Quality Center Homer City, PA 15748-0280 • Phone: (412) 479-6016 
Individual compuler modols will bo mado commercially available (seo sidobur for dolails) as they ara developed. 'Tho lirst of these models, the Acid Rain Advisor, will be ready for use in lale 1991. 'This model deals with complianco options for addressing the acid rain provisions of the rocently amended Cloan Air Acit. Specifically, this Act provides tatilities with allowances for $\mathrm{SO}_{2}$ emissions. These allowances can be traded botween powor plants and betweon ulilly systems. 'This allows tradeofl's to bo mado regarding use of scrubbers, fuol cleaning, fuol swilching, and other approaches as compliance options. Ovorall, the Acid Rain Advisor will provide a utility with a powerful tool for evaluating possible options al individual plants at the overall systom lovel and for considering trading emissions allowances with other utilities.

The Coal Qualily Expert will include cost estimating models for new and retrofit coal cleaning procossos, power production oquipment, and emissions control systems. When tho Coal Quality lixpert is complete in 1994, users will be able to develop the most economical emissions control strategies, identify fuel options based on overall plant economics, and evaluate altemative power plant designs.

The Coal Quality Lxport promises to be a powerful source of coal quality information. Users will be able to ovaluate the lotal cost impacts of difforent coals and coal qualities on power plant performance and emissions. With the Coal Quality lixpert, utilities and industry will be able lo hold down the costs of generating electricity al coalfired plants while protecting the environment.

Consistent with the intent of the National Enorgy Strategy, implementation of projects like the Coal Quality Expert and the other projects in the Clean Coal Technology Program will allow us lo use coal, Amorica's most plentiful onergy resource, as one of tho cloanest and most economical sources of elocitrical power. As the models become available, wo will keep you informed in the "Update" section of the PETC' Review, and wo will continue to provide addilional arlicles describing the research and results of the Clean Coal 'Technology Program.

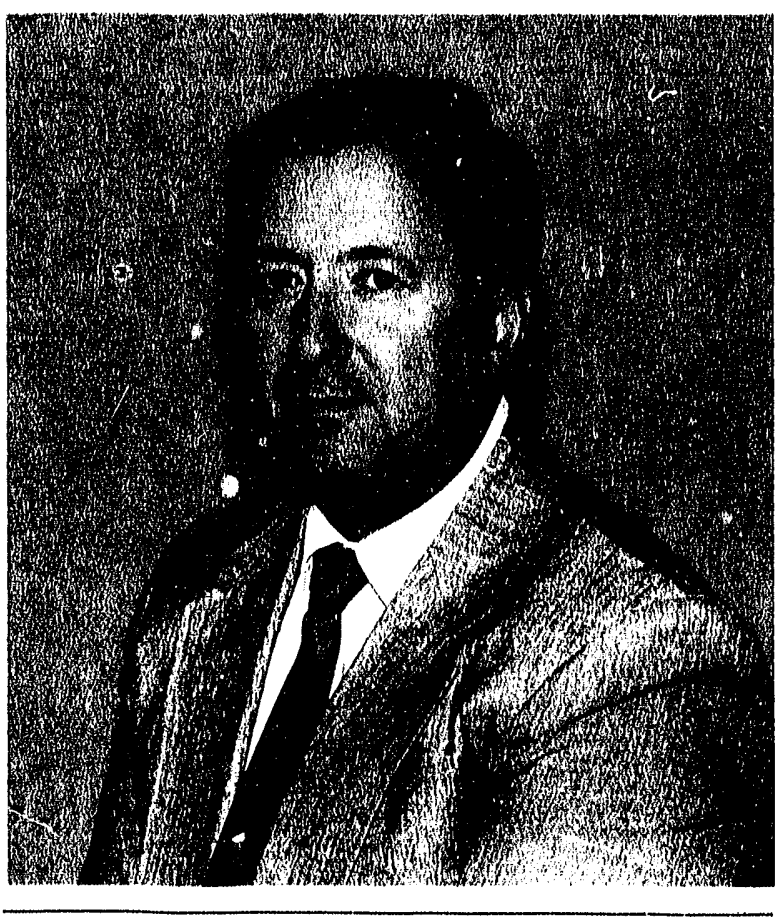

Robert J. Evans joined DOE' as a Project Manager for the Office of Clean Coal Techonology in Januany 1989 and is overseoing three projects: Coal Quality Expert, WSA-SNOX (Wol Gas Sulfuric Acid-SO, and NO reduction), (and LIFAC (Limestone Injestion into tho Furnaco with calcium oxide Activalion). Bob received a civil ongineoring degree from Geneva College. In subsequent years, he earnod a mechanical angineering degroo and master's degroes in civil and mining onginesering from the University of Pillsburgh. Bofore assuming his current position, Bob worked for 4 yeers's al the U.S. Burecul of Mines as a projeret manager in the Advanced Mining Systems Division. While working previously for DOR, Bols served as a projecal anginoure in the Coal Liquesfation Division and as a branch chicef for Cool Mine Dovelopment and production. 


\section{UPDATE}

\section{United States Clean Coal Technology Exported to Poland} (Issue 2, September 1990)

$\mathrm{I}_{\mathrm{n}}$ In addition to providing retrofll lochnologies for romoving sulfur dioxide ( $\left.\mathrm{SO} \mathrm{O}_{2}\right)$ from current powor plant omissions in Poland, the Unted Stalos Agonciy for International Dovelopment (through DOE/PIE'TC) is providing assistanco in holphing the Polish people to develop cileaner melhods for burning their indigenous coals in small boilors and home hoating systoms. In Krakow, thoro aro noarly 3,0(0) small boilers totaling $300 \mathrm{MW}(1)$ and 200,000 home healing sloves that burn coal. This past June, PEYT'C inilialed an assessment of existing practices and equipment and will investigalo several simple methods to reduce omissions, primerily organlis and particulates. With the help of Brookhaven Nalional Laboratory and Biuro Rozwoju Krakow (the Provinco of Krakuw's planning agency), pilot losts will beconductod on districl bollers and home stoves. Data colleciled from these lests will be combined with ongineoring analyses to provide a coordinaled data base for detemining equipment and strategies that will be offective in reducing pollution. This project will involvo the use of U.S. lechnology, and it is expected that alliances will be formed to foster businoss ventures betwoon U.S. and Polish firms.
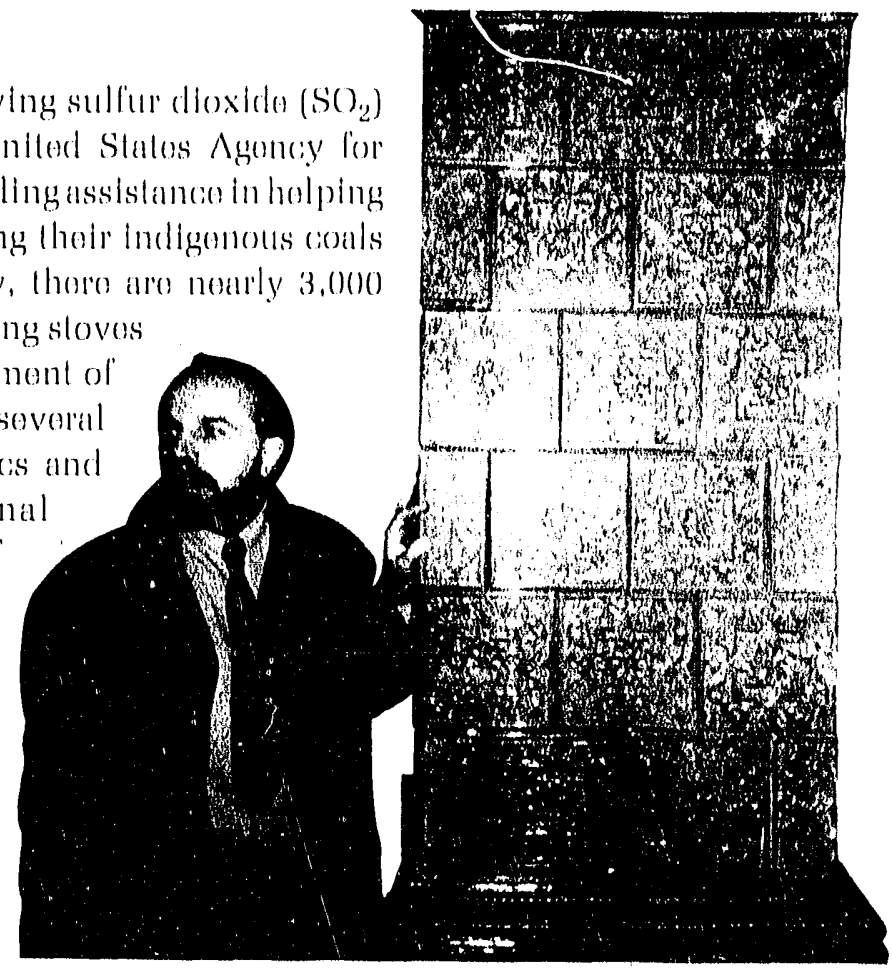

Dr. Krzysztof Görlich, shown standing next to an elaborately decorated flue for one of the 200,000 home heating stoves in Krakow, Poland, is a member of the U.S. /Poland

Boiler Manufacturer Chosen for U.S./Italy Superclean Coal-Water Slurry Demonstration (Issue 2, September 1990)
A
se reported in Issue 2 of tho PETC Roview, a boiler manufacturor had hoon selected in a project to demonst rato that superclean (about $1 \%$ ash comlenl) conal-water slurries produced from U.S. coals can be burned in boilers designed for oil, withoul sacrificing efficiency or harming the environment. Sinco that roport, a 15 million-B311- per-hour Keeler boiler has been installed in a now building at the las Campus healing plant on the grounds of Pennsylvania Slate University. The boiler is large enough to heal dormitories for 3,000 studonts. The demonstration began in fuly using Brookvillo seam coal from Porry Brothers Coal Company in Sharon, Ponnsylvania. Tho coal is cleaned near the mine: shipped lo KVS in Danville, Ponnsylvania, for colal-water fuel preparation; and then trucked lothe: University. Thos study will concilude in December 1991. In addition to providing informulion aboul rolrofitling oil-designed hoilors (o) coal-water fuels, the data will also provido importanl guidanco on how lo design boilers for use with these conl-based fuols. and Krakow City Council. He has been appointed by both the Province and City of Krakow to monitor environmental facets of various programs, including the DOE/PETC Clean Coal Technology project. 


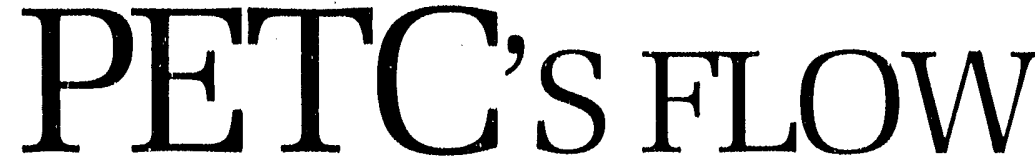

ANALYSIS LABORATORY ASSISTS ARTIFICIAL HEART RESEARCH

"A preeminent exaniple of the benefits of creative lechnology transfer. Not only' is DOE's research investment enhancing our energy' security, but that same investment offers an opportunity for the medical community for research that can literally save lives."

Jamos D). Walkins Secerelciry of Energ!'

I In the pass 10 years, a cardiothomacic surgery leam led by hoart transplant surgoon Dr. Bartley Griflith al Presbylorian-University Hospilal in pillsburgh has performed severial slate-or-the-arl proceduros: a heart-lung transplant in 1982, al heterotopic heart transplanl (al procosss in which the original heart is left in placeo and an addlitional hearl is transplanted into the body that acis als a teft ventricular alssist dovica) in 1984, and a doublo lung transplant in 1988, In 1985, they became the second team to use the Jarvik lotal arlificial hearl ('I'AH) als a bridge lo condediac: Iransplantation. In the last fo yours, 20 patients have been supported by tho Jarvik 'T'AH and 2.5 patients by another heart pump, the Novacoor Leff Ventricularl Assist Device (LVAD)\}. This makes Pillsburgh's local hearl lransplant cenler one of the world's most active and the worlul leader in the use of the Novacos l, VAD.

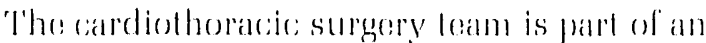
exlensive artificial healrt restarch program al
Tha Univarsily of Pillshurgh's ProsbylorianUnivorsity Hospilal. (Ono of thoir main resoursh objectives is lo improve tho homodynamias, or blood flow behavior, in artificial hoart pumps in an offort lo incroase palient survival rates and longthen thoir coloranes to tho artilicial hoart implants. In (ochober 1900), modicial resoarchors led by Dr. Harvey Borovel\%, Direstor of Bioenginesering for the Artificial Hoarl Program, askerl PET'C (o assist his toam in lheir study of hemodymamics in andilicial hearl pumps.

Advanced diagnoslic: arpuipmont devoloped by

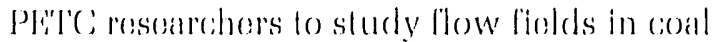
utilizalion poocossess is now boing appliod lo

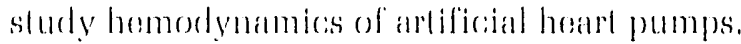
'the sludies are boing performed in PFTC"s Flow Analysis baboratory by a toam of ressoarchers from

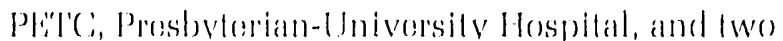
artificial hearl pump companies. Under this

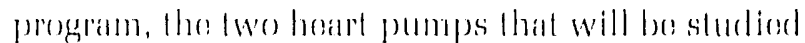
are the Novacor L,VAI) and the Nimbus $A$ xipump. 


\section{The Novacor Left Ventricular Assist Dovice}

$\mathrm{O}$ no of tho mafor probloms facing pallonts wilh lorminal hourd disomse is tho avallabilily of donor hearls for lementanl, Ganch your an ustimalud 30,000 pantents are in nood of a lansplanl, bul only aboul 2,00) accopplablo doror hourts are mado avallablo. As a resull, many pentents who aro candidates for transplant suldgery do not survelve untll a clonor hoart becomes avalahle.

Tho medical communily is allomplong to bridgo tho limo gap bolwon hoard failuro and cardiac: transplant wilh tho use of arlifteid heart pumps.

T'odely, emphasis is boing diresited loward using dovicos that assist an ailing henet insload of' roplacing 11 will a tolal ardiflidal hemer such as

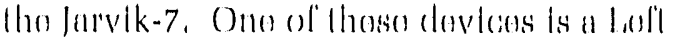

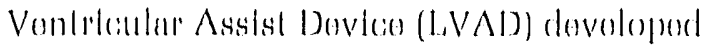
by Novacon', a Division of Baxlor Honllacian'o (sou ligutes 1 and 2). 'Tho succioss ralo wilh tho Novecor LVAD is very ancouraging - mores than $70 \%$ of tha Novacos L.VAD implant pallonls al Presbylorian-Univorsily Hospllal havo hoon kopt alive until a donor hoart was found.

'I'he shortage of donorergans and the recpulromont for a good "malch" bolwoon donor and rociplont is now slgnifleanlly incrousing the longlt of limo an LVAD implant must bo used. At the lime this arlicile wes wrillon, a paliont al Presbylorian-Unlvorsity Hospital had been kopl allve wilh tho Novacor l. VAD for more than 300 days. Over these axtended portods of contact between the pallont's blood and tho arlificial surfecies within the LVAD, aven subllo

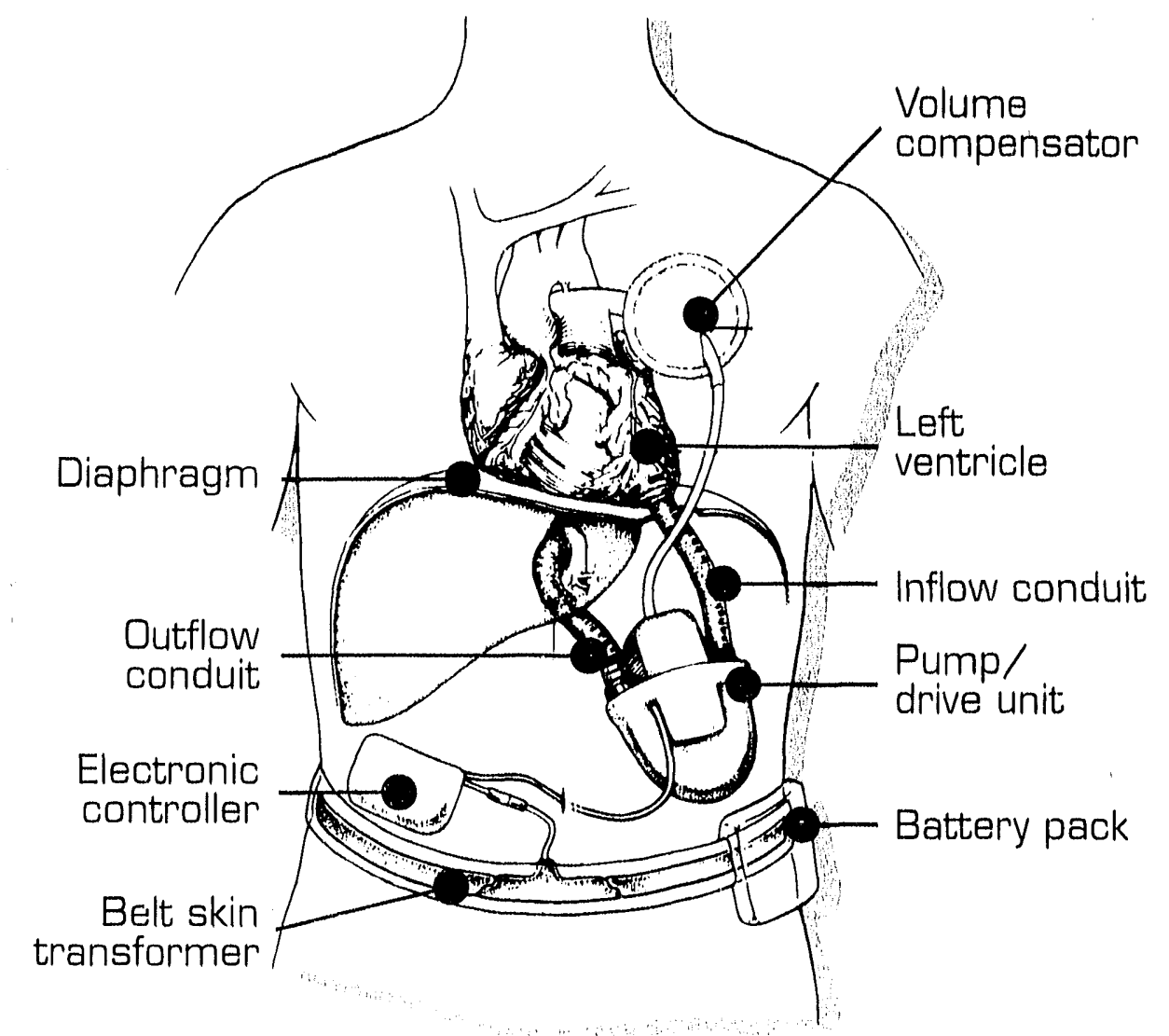

Figure 1.

Arrangement of the Novacor LVAD in the human body: as shown, the LVAD is powered by internal batteries and an external strap-on battery pack and is controlled by an implanted miniature computer. Figure courtesy of Novacor, a Division of Baxter Healthcare. 


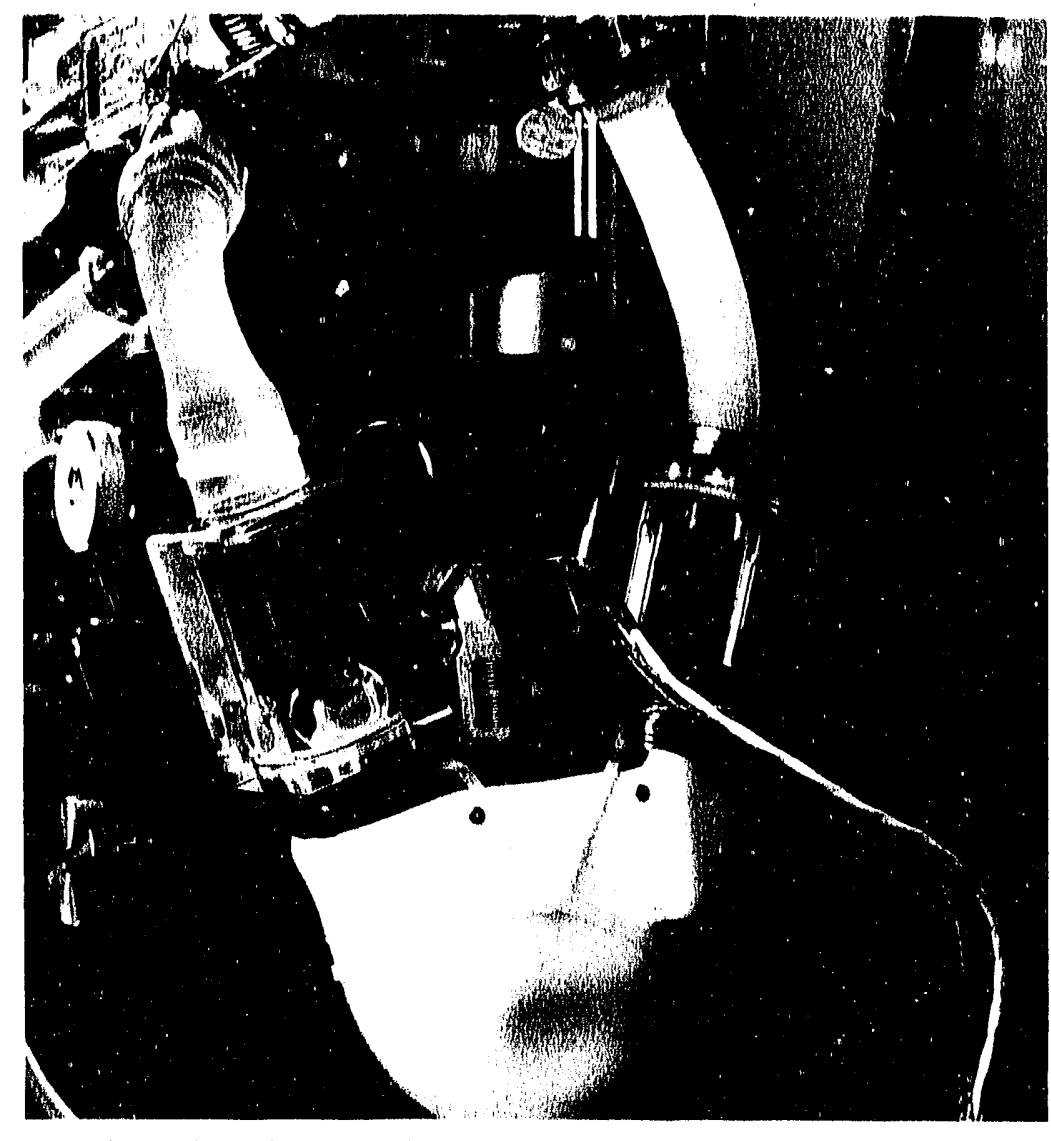

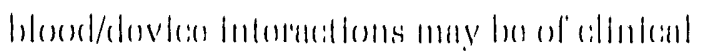

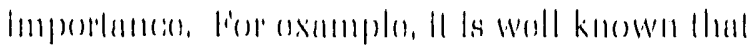



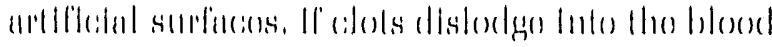

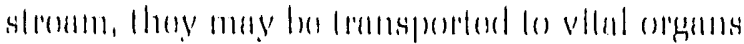

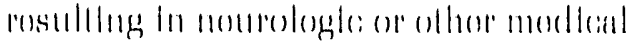
(iomenllcalloms.

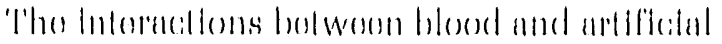

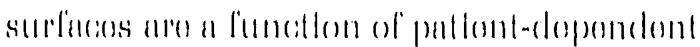

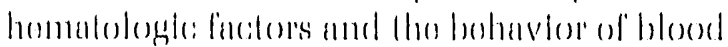

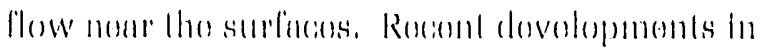

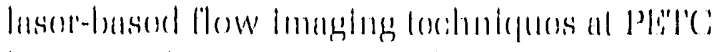

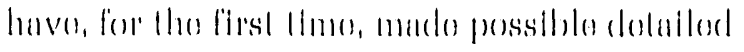

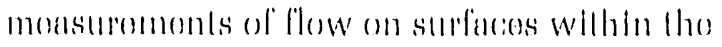
Novaloor L.VAD,. 'I'hose dovelopmonts allow

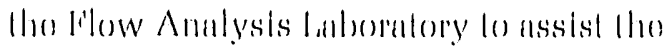

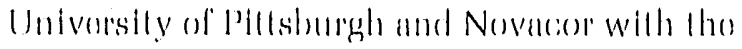
Incirmsingly complex analysis of bloos flow

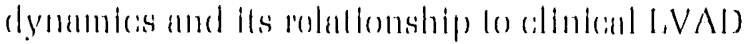

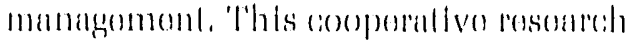
combribulos to tho continuing affort fo optimizas devico porformancon and tho goal of impresving tho

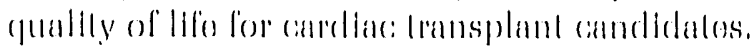

Figure 2. Novacor LVAD set up in PETC's Flow Analysis Facility. Note that transparent housings have been added to visualize flow around the inlet and outlet valves.

$\mathrm{T}$ This proforl is boing porformed under a Cooporativo Resourch and Dovolopmont Agroomont (CRADA) which is just ono

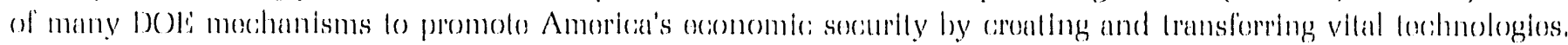

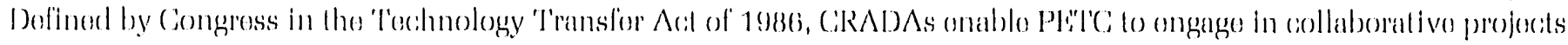

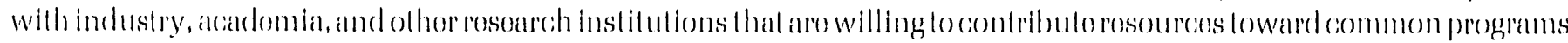
and projocils.

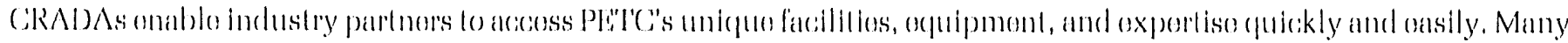

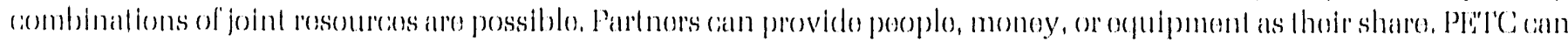

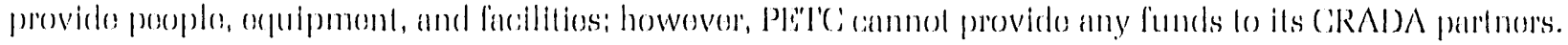

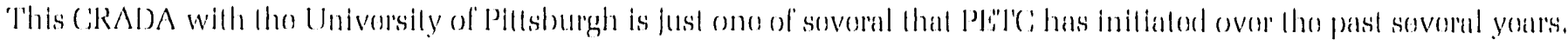

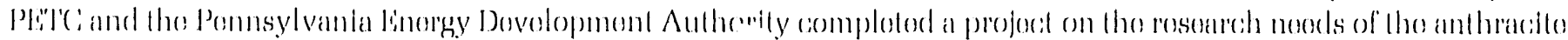

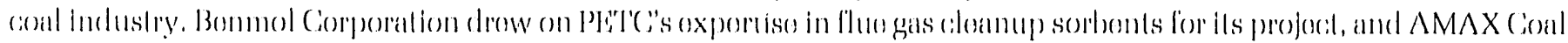

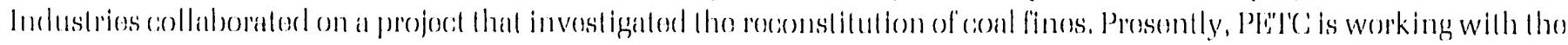

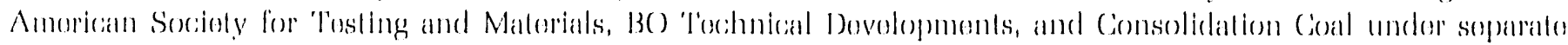
similar arrangomonts.

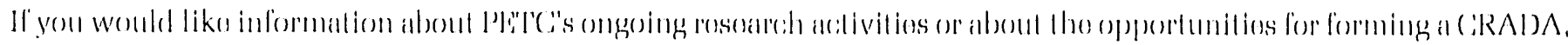

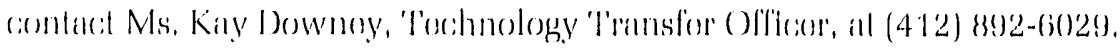




\section{The Nimbus AxiPump}

A miplantablo hearl dovico belng studiad at Pist'C is tha axtal flow pump, devolopod by Nimbus Inci, and known as tho Axipump (ligure 3). 'I'his is a revolullonary minlaluro LVAD consisling of a small turbine tho stzo of a ponlight battory (soe riguro 4). Ono of the many advantages of ils small sizo is the reduced surfuce area in conlact with blood. Another unlquo foalure of tho AxiPump is that, rather than being pulsalile liko the human hearl. it is a conllnuous flow device. An Axipump) patient with a very weak hoarl would havo no significant pulse or systolic/diastolic blood pressure. According to Presbylertan-Univorsity Hospilal modical resourchors, Has dovice could signilicantly reduce the domand for donor hearts and has the potential lo save up lo 30,000 llves per yoar.

For the AxiPump to work properly, the shear strossos imposed on blood musl be kepl within a narrow range. Excossivo shoar strosses cán damage blood colls, while very low shour stressos tend to promoto blood ciloting. Tho flow velocitios and resulting shear stresses in the AxiPump aro being measured in the filow Analysis Laboralory using high-spood photography and pulsed laser imaging techniques.

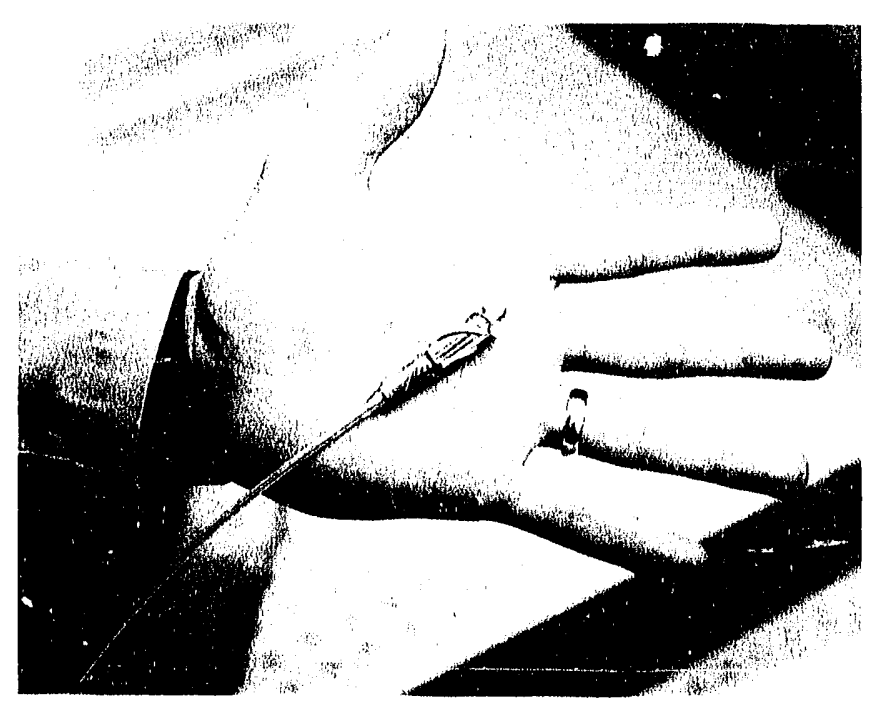

Figure 4. The rotary turbine of the Nimbus AxiPump.

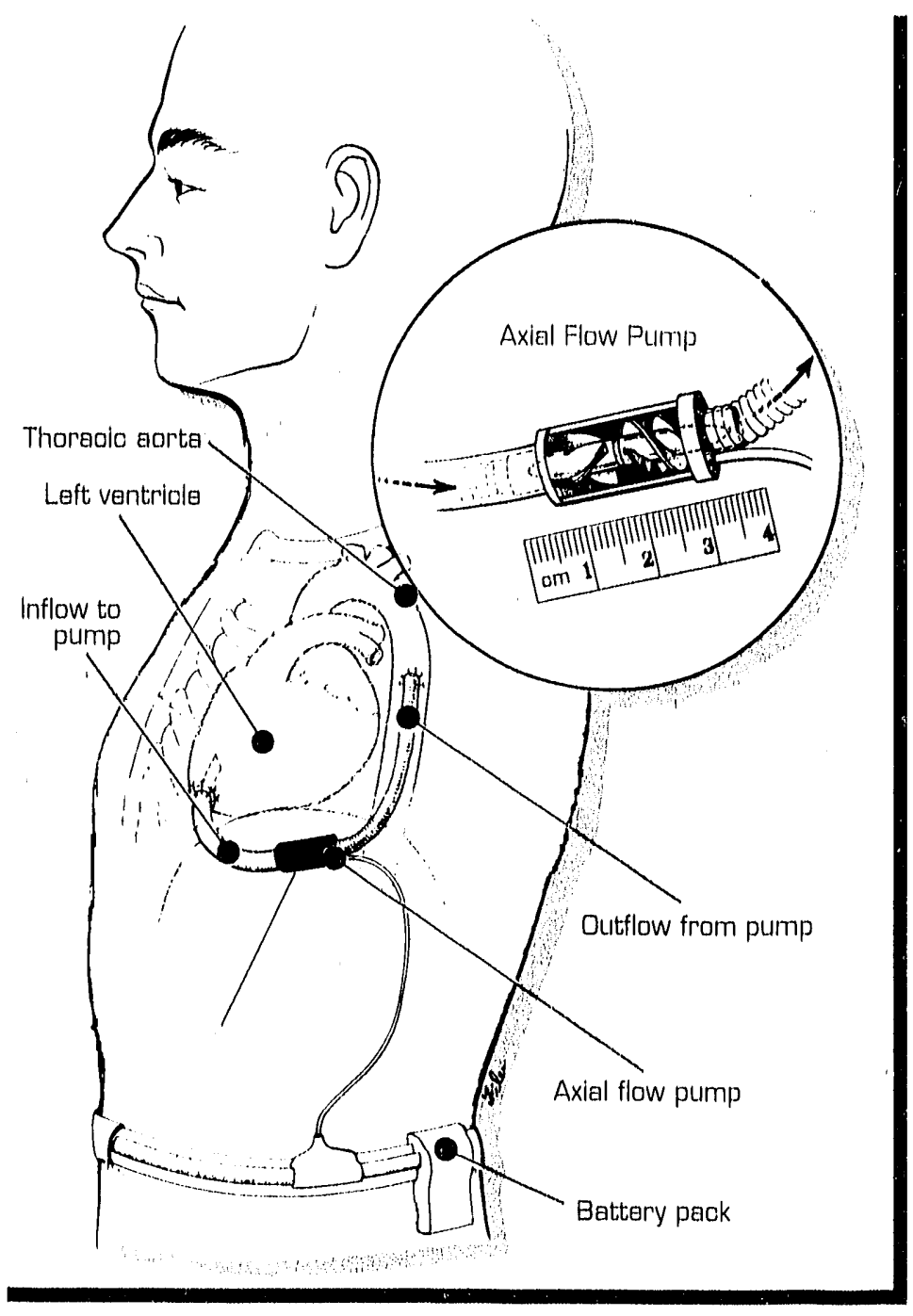

Figure 3. Location of the Nimbus AxiPump between the left: ventricle and the thoracic aorta. Figure courtesy of Nimbus Inc. 
This is a formidable lask becianso flow flolds must be monsured across a millimolor gen bolwoen lurblno blacies that aro splnoning at 12,000) revolutions por minule.

\section{PETC's Flow Analysis Facility}

$\mathrm{T}_{0}$ Io study "mulliphase" fluid dynamics in conl ullizallon processos, rosenrchers have dovolopod a stalo-of-Ho-arl Flow Analysis Laboratory (soo Figuro 5). This lab foulures a wind tunnel designad to simulate flow fiolds in conl ullitzalion processes, Sophistlcatod flow diagnostic: oquipmont is usod to moasure flow fledds in tho wind tunnel. This flow diagnostic oquipment includes a pulsod laser lmaging (PLI) system and a laser Dopplor velocimeler (LDV). The PLI systom, which was designod and devolopod at PETC ovor tho past 5 yoars, uses digital photography to map flow fiolds. 'This system omploys a pulsed copporVapor laser as a special strobe light to illuminate mulliple-exposure digital photographs of particilo motion in a flow field. Tho digital photographs aro analyzod to oxtract guantitative flow information using a compuler workstalion with parallel processing capabilities. PETC researchers have published soveral articles doscribing tho design and application of PLI systems.

One of the main applications of tho Flow Analysis Liaboratory is the analysis of flow fiolds that occur in hoat-oxchanger lubo banks of coal-fired boilers. Figure 6 shows a picture of simulatod streaniline motion over a steam tube in the wind lunnel. 'These flow fiolds gevorn the heal transter and ash doposition procosses in hoal-exchanger tube banks. The llow Analysis Laboralory has also been used to analyzo the behavior of spreys used in flue-gas dosulfurization systems and flow fioldis in coal cheaning exporiments that moasuro tho Irajectorios of charged particies subjoctost to oloctromannelic: fiolds.

\section{Medicine and Coal Research Meet}

$\mathrm{U}$ nder the berms of the (RADA, Pl:I'C: and medical rosoarchers from the University of
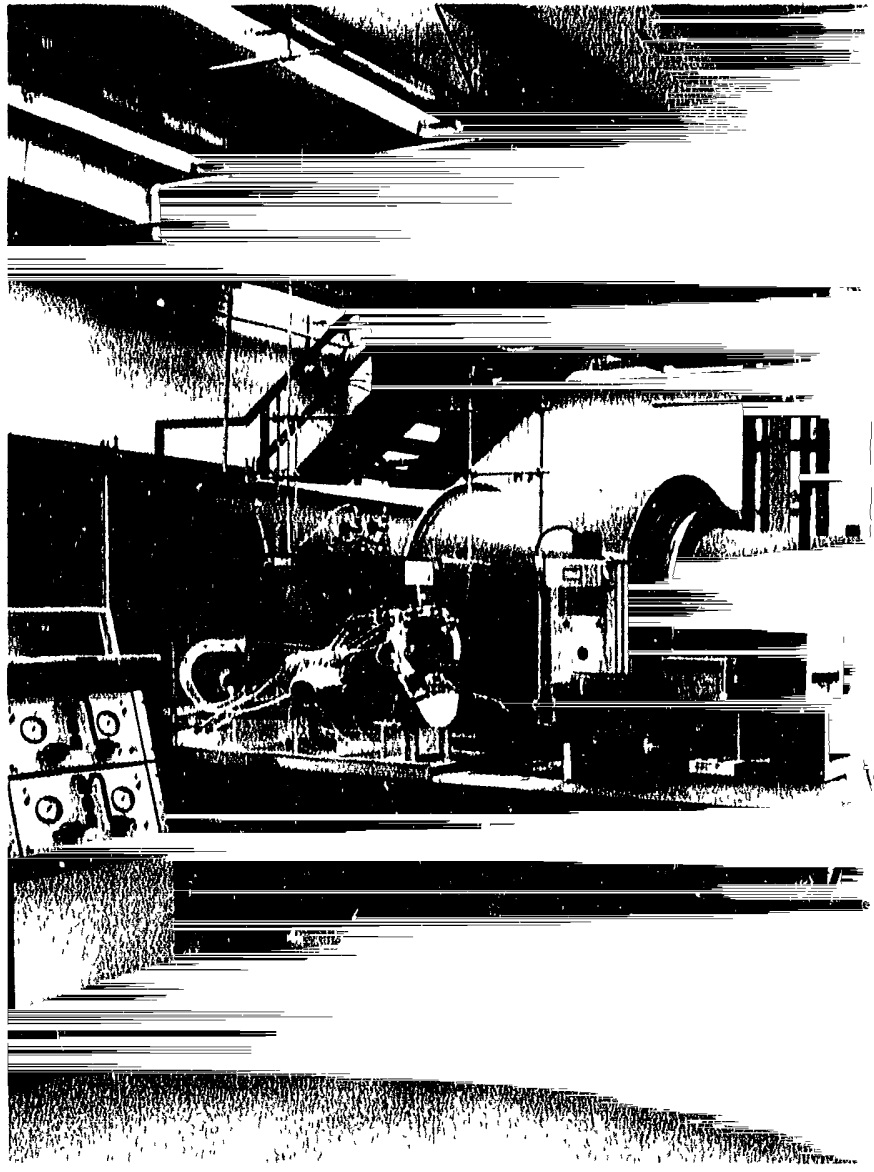

Figure 5. A view of the PETC Flow Analysis Laboratory.

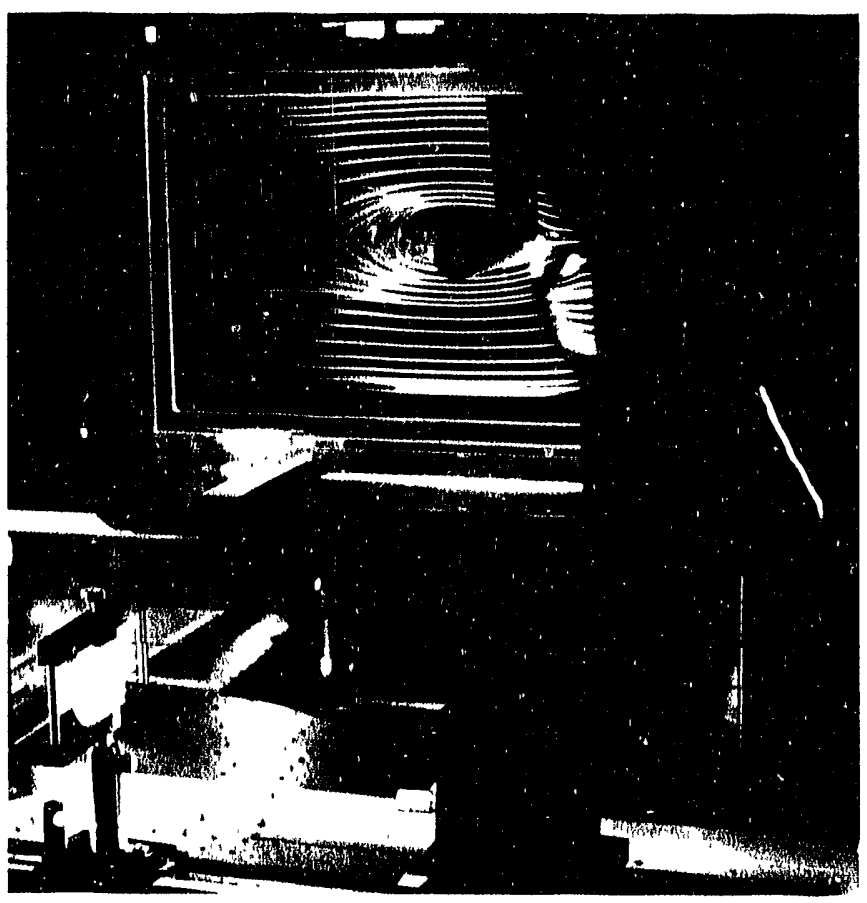

Figure 6. Simulated streamline motion over a steam tube in the wind tunnel. 


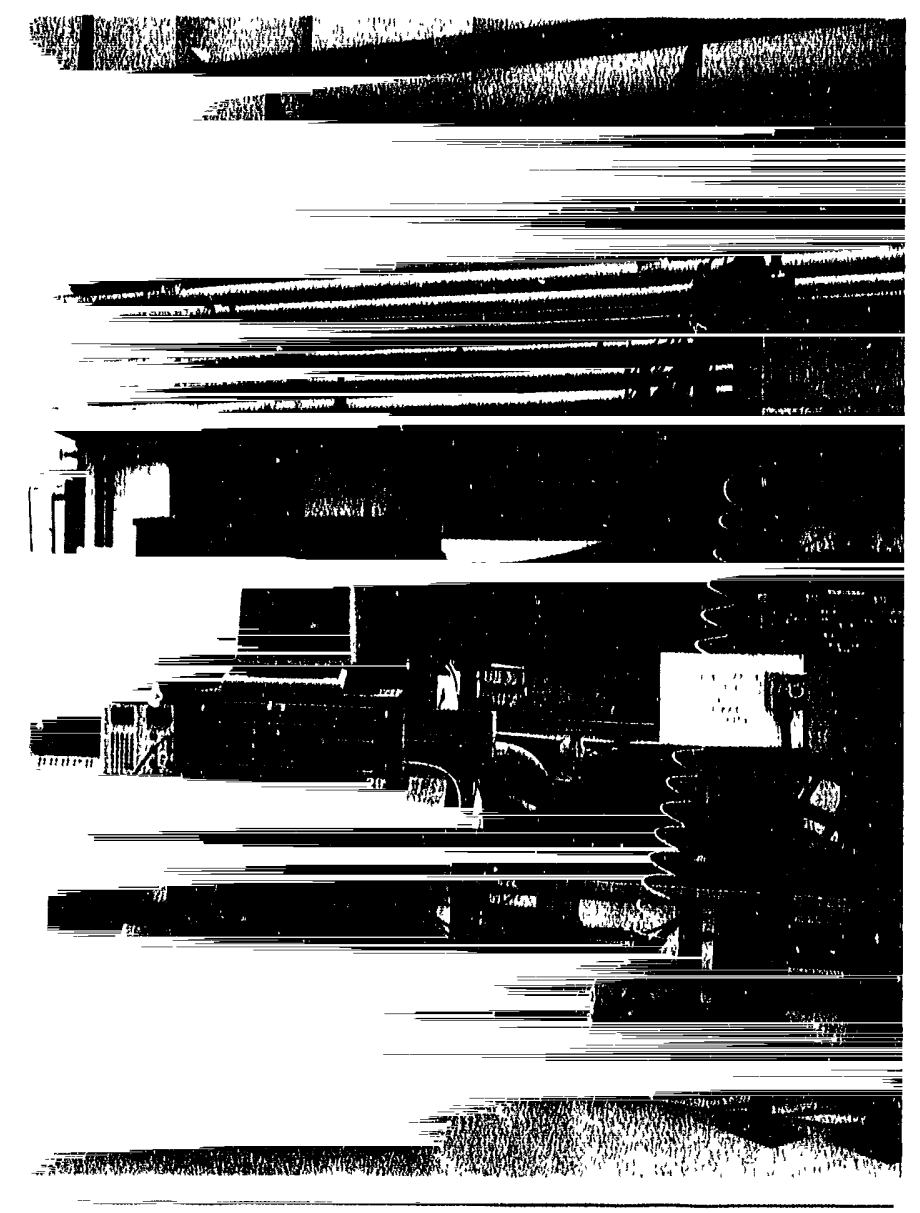

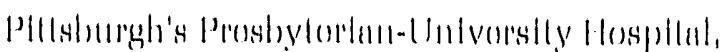

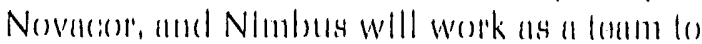

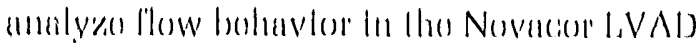

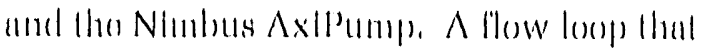

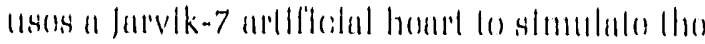

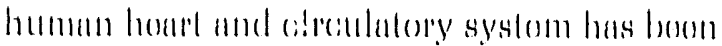

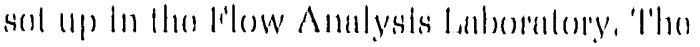

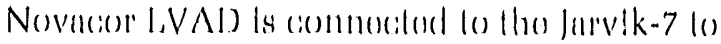

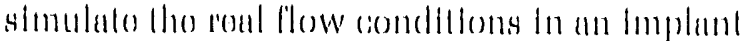

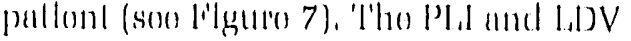

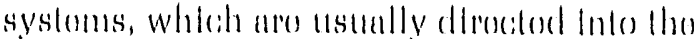

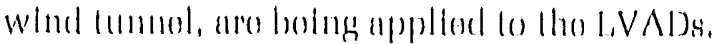

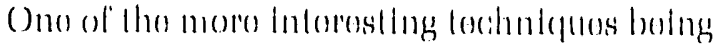

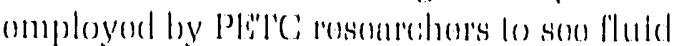

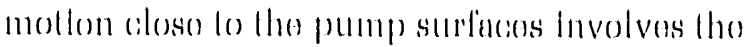

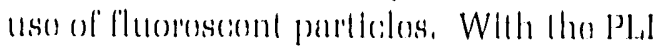

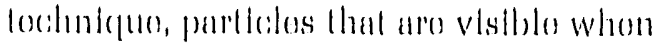

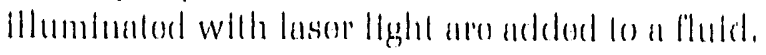
'I'hoy aliow tho flude mollon lo bo semen, and thoy also mimle tho mollon of blood colls and platolols. Ilowover, the perliciles camonol bo seon very cilose fo a pumpe surfaco becianso of tho intenso glaro of lasere light roflecilod from thes surfaco. 'lo soo the partlalo mollon nour tho

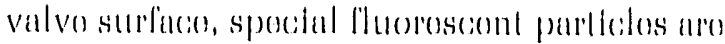

Figure 7

The Jarvik-7 and Novacor LVAD set up in the Flow Analysis Laboratory.

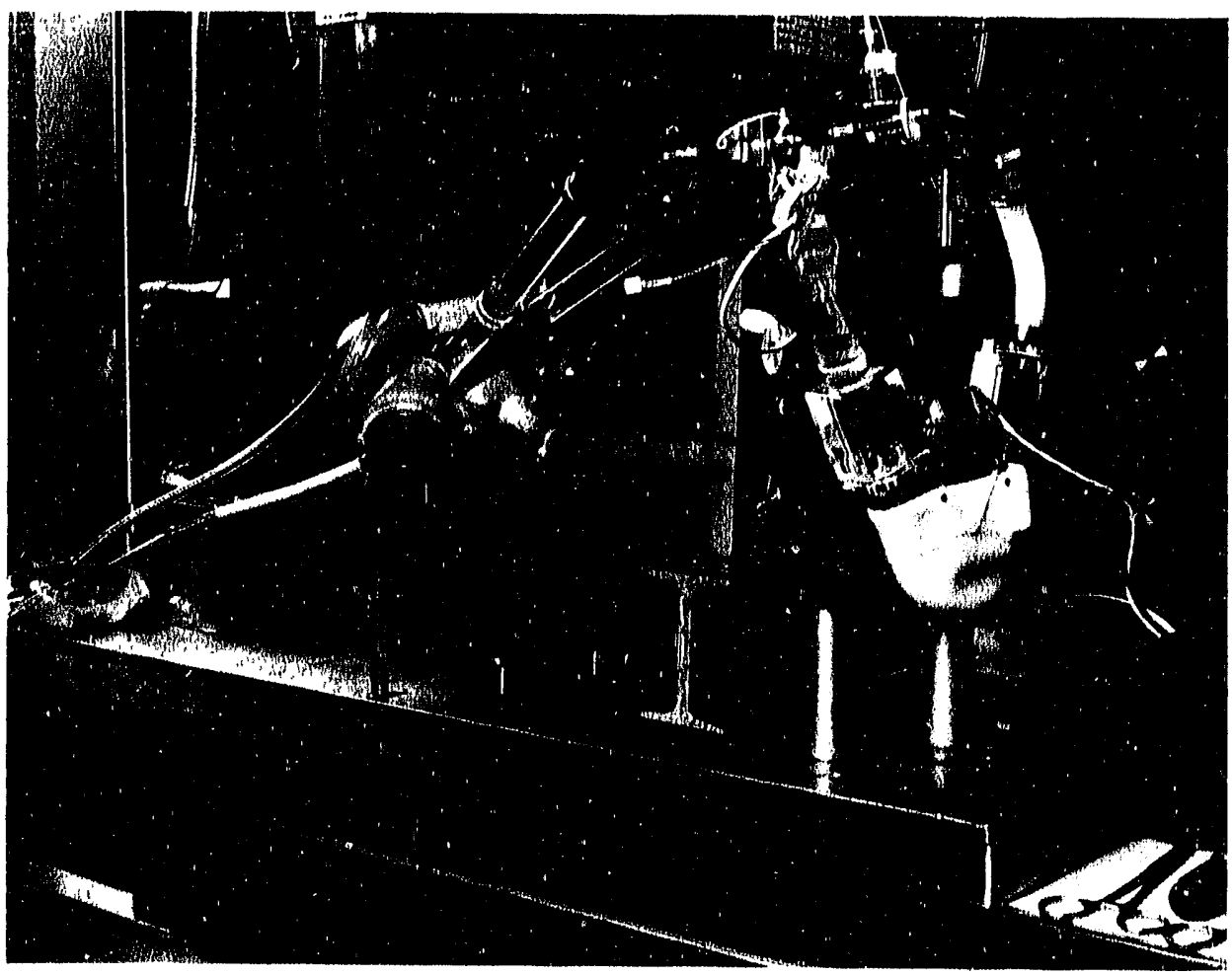




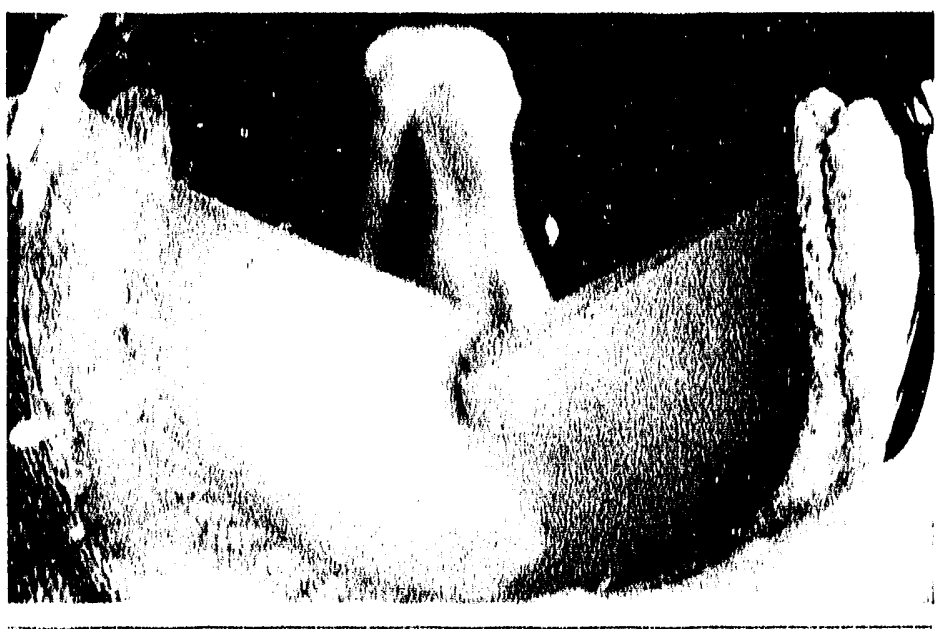

Figure 8e. The pericerdiel trilegflel outflow velve of the Novecor LVAD (a magnified view).

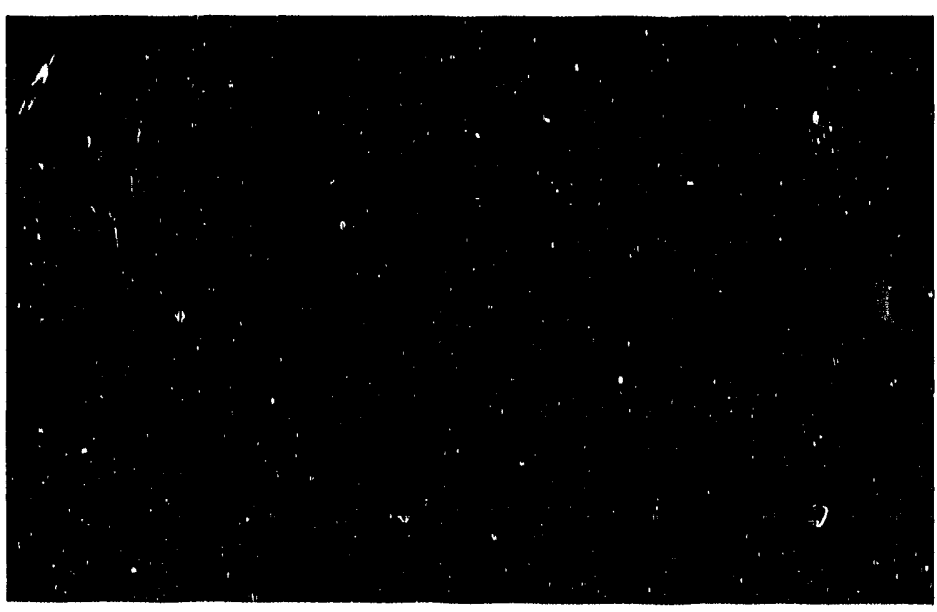

Figure 8b. Fluorescenti perticle motion around the pericardial valve of a Novacor LVAD.

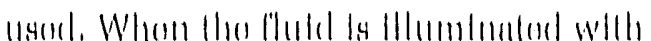

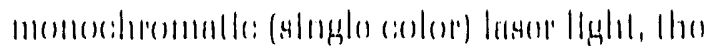

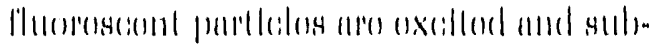

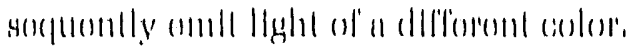

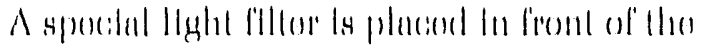

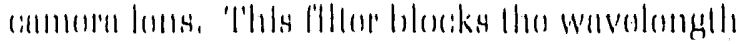

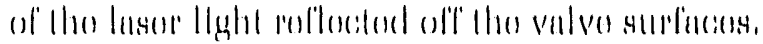

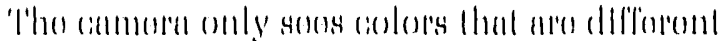

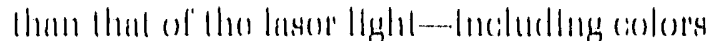

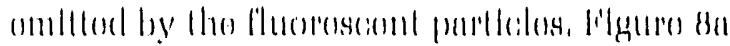

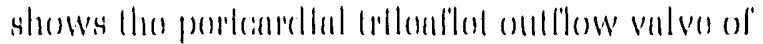

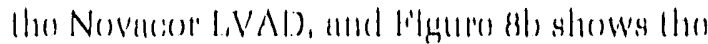

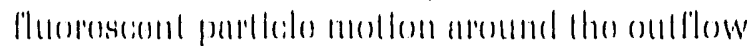

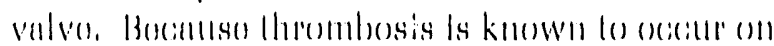

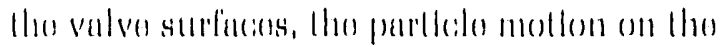

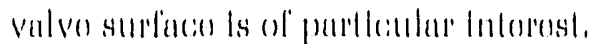

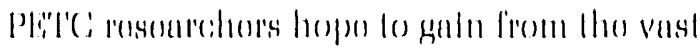

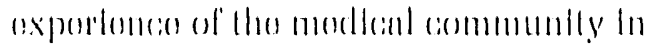

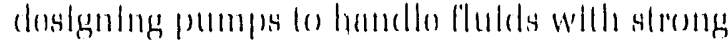

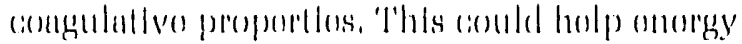

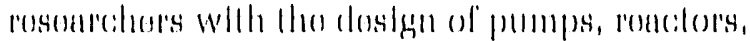

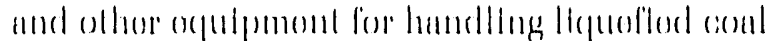

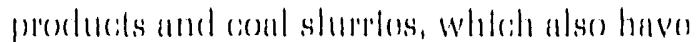

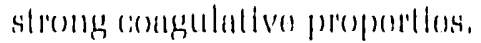


"We are extremely excited about the opportanitiy to make those olinically roloventi moasurementis in the state. of thenarti PETC facilitiy. We believo that the information wo obtain will guide the design of ounventi and futille heart pumps."

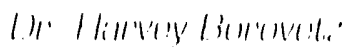

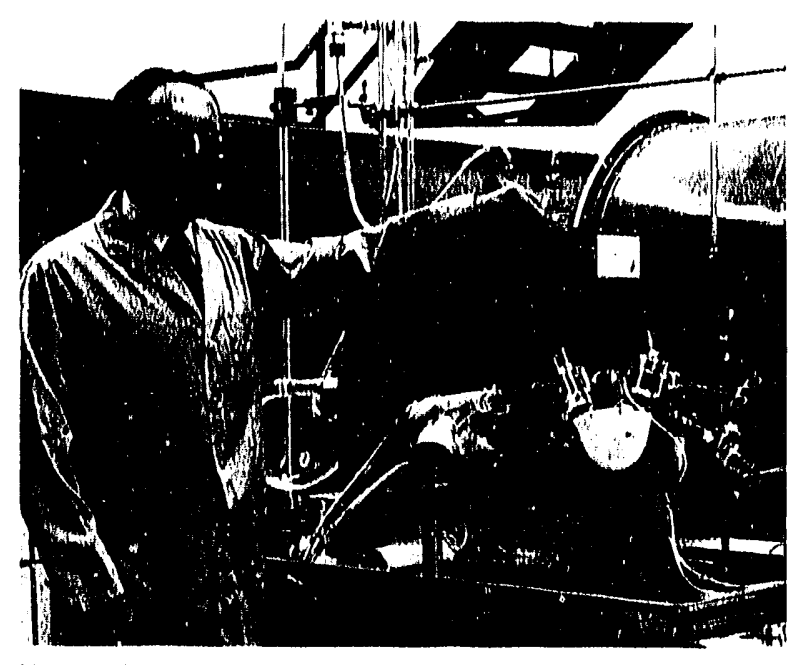

Harvoy S, Borovolza, Mh, l), Is l'molissoul ol'

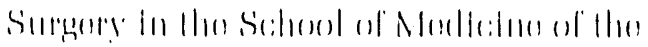

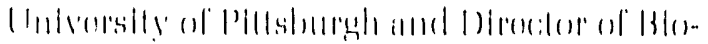

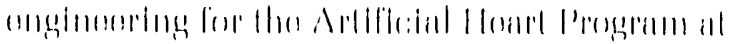

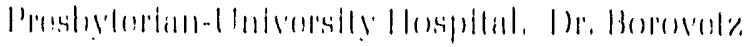

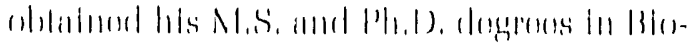

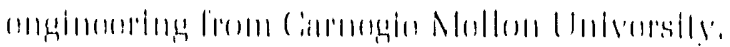

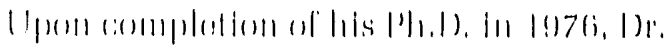

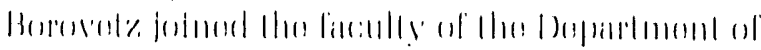

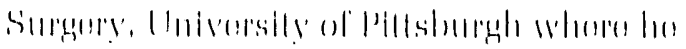

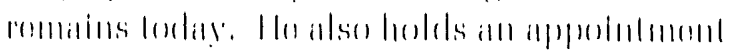

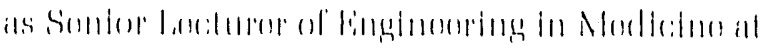

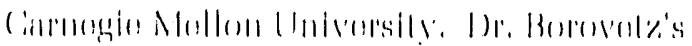

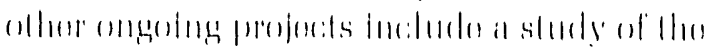

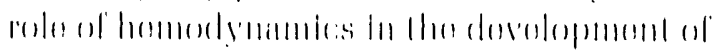

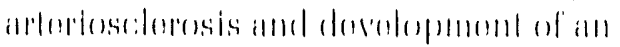

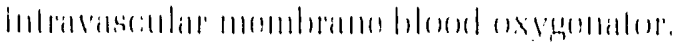

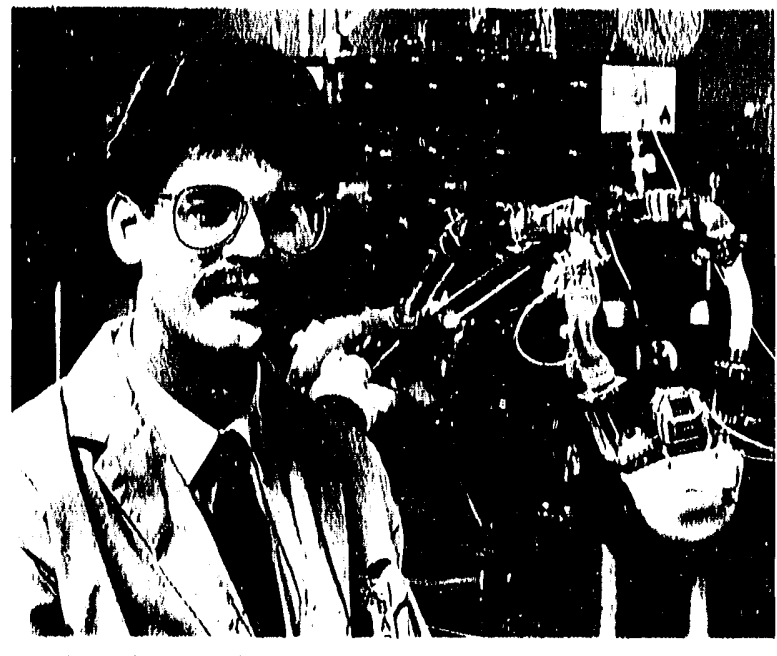

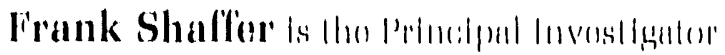

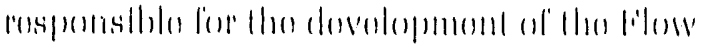

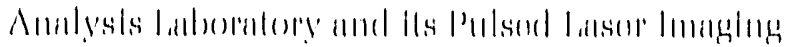

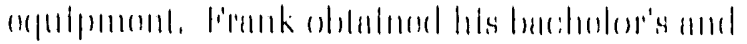

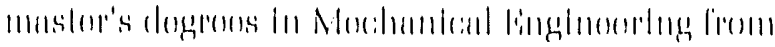

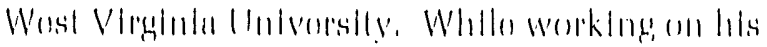

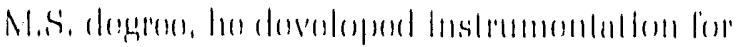

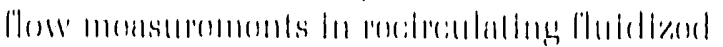

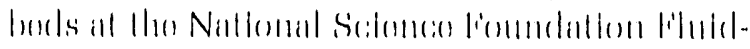

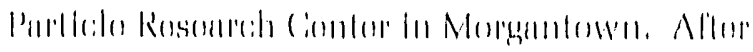

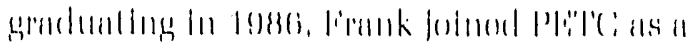

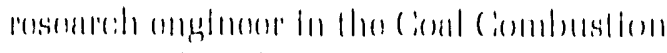

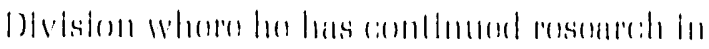

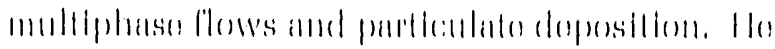

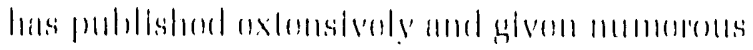

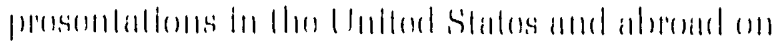

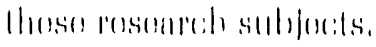

Use of materials, products, or services by the Departinent, of Enercjy does not: constititite an official andorsemant; by the Depertanent. 


\section{Focus ON}

\section{Curt M. While}

$D$

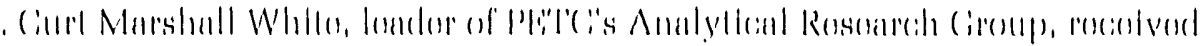

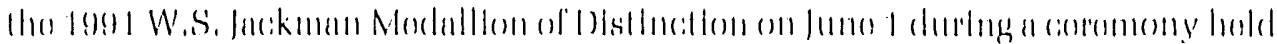

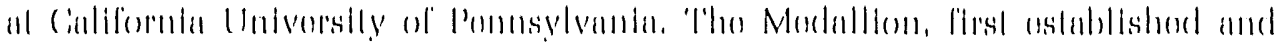

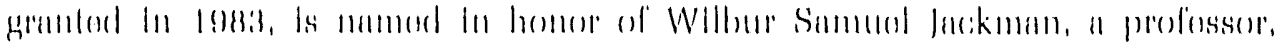

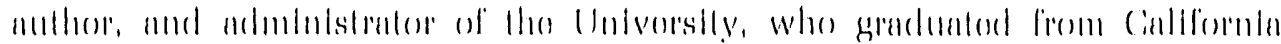

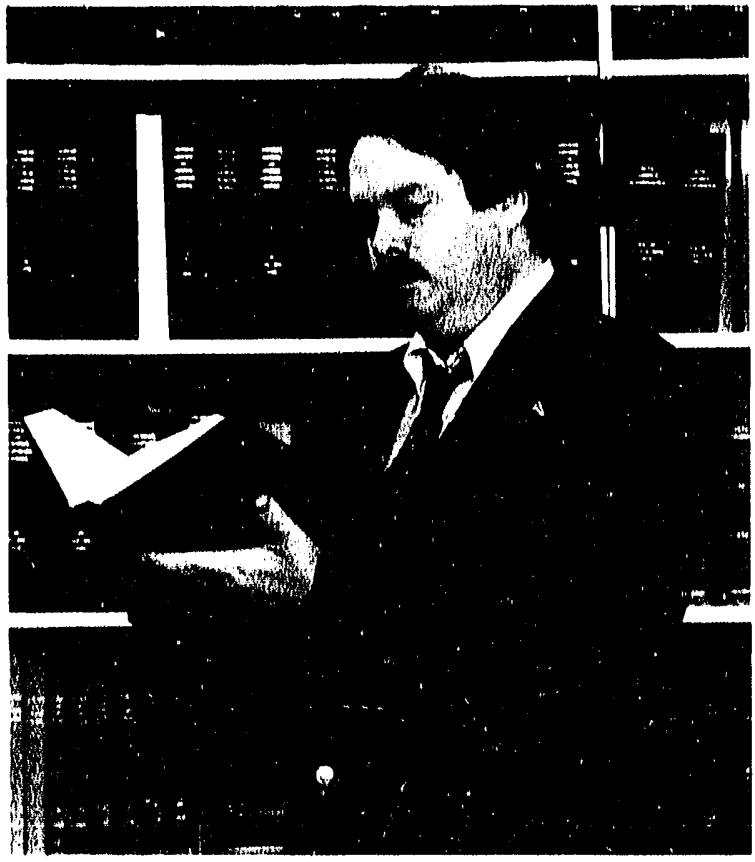
In 1877. Profussor Jackinan was known

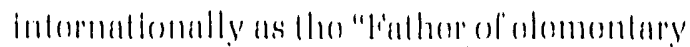

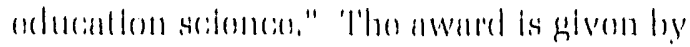

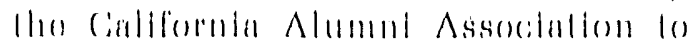

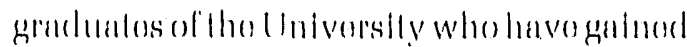

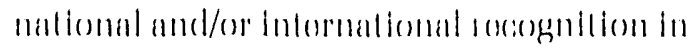
thold professitons and huve distingubahod bolle thomsolvos and thotr almo mator.

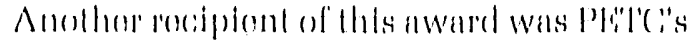
own Horl Rolcolisky.

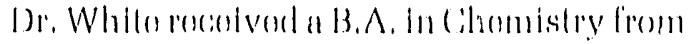

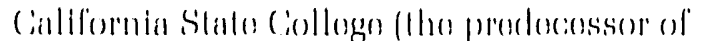
('alifornia (Juiversily of P'onnsylvanial), an M.s. in Cihomistry from tho Inivorsily of Norlh Dakolia, and a Ph. D, inc (ihomisley from Dolyunsone Inoversily. Ho has oxlonsive

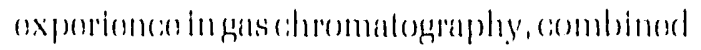

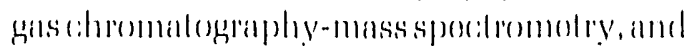

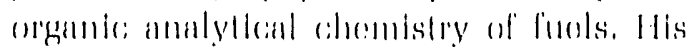

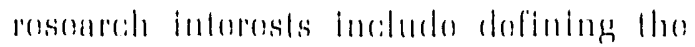

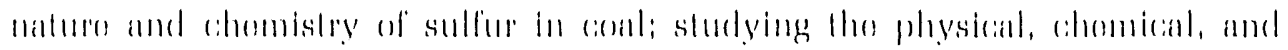

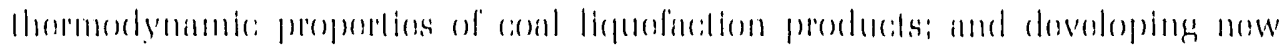

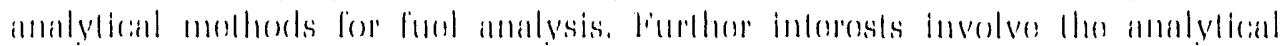

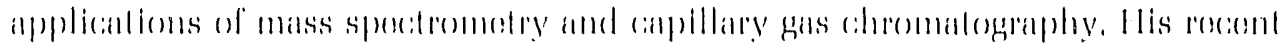

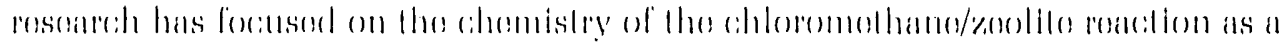

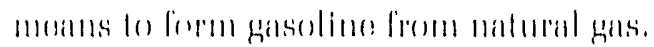

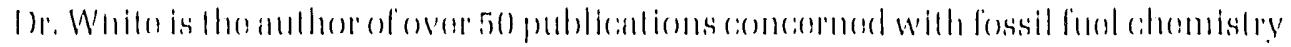

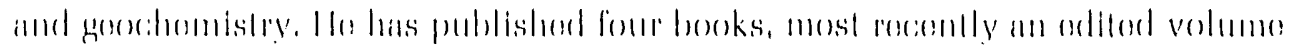

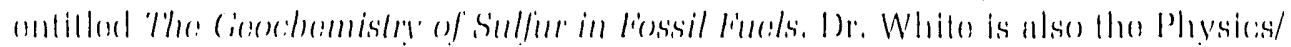

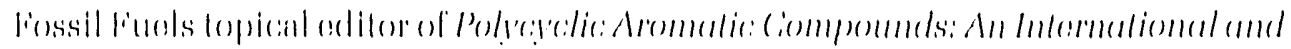

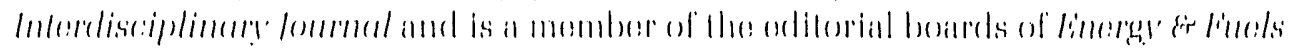

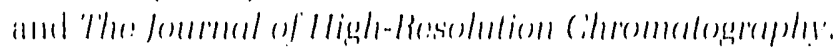

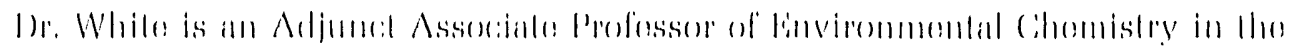

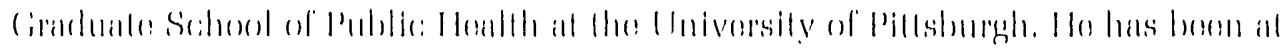

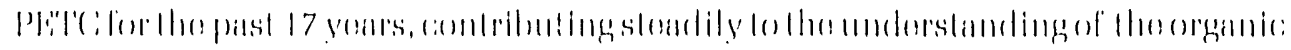

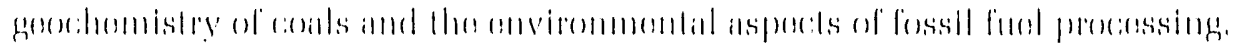




\section{HigHLiGHTS}

\section{Coal Preparation Process Research Facility Completed}

PETC's Coil Preparation Process Research Facility (CPPRF) has been completed and is currently undergoing shakedown testing. This state-of-the-art, continuous benchscale facility will accommodate a wide variety of advanced fine-coal cleaning and handling processes, circuits, and equipment for testing of 100 to 500 pounds per hour of feed coal. The CPPRF is comprised of three areas that can be operated independently or in series for flexibility: (1) a permanent conventional precleaning circuit, (2) a permanent three-stage grinding (comminution) circuil, and (3) an open, emerging technology area for short-term incorporation of other modules or equipment on a sequential or concurrent basis. The use of this continuous, bench-scale facility will offer a critival link in the scale-up between applied research in the laboratory and proofof-concept or demonstration testing.

PETC has identified activities in advanced coal beneficiation technology development to be conducted in the CPPRF in Fiscal Year 1992. These activities will be of four general types: (1) outside contracts resulting from competitive DOE solicitations; (2) Cooperative Research and Development Agreements (CRADAs) with industry and other private-sector groups; (3) scale-up of bench-scale processes developed at PETC; and (4) bulk preparation of specification coals for other coal utilization technologies. For example, PETC is currently running a solicitation for continuous, bench-scale testing in the CPPRF of high-efficiency coal preparation equipment/ technologies for fine coal. Contrast awards will be made in 1992.

Raw coal (up to $150 \mathrm{~mm}$ in size) will be received outside the CPPRF and reduced to $6 \mathrm{~mm} \times 0$ top size in a four-roll crusher. It will then be conveyed into the CPPRF and stored in one of the two 5 -ton feed storage bins for use in the different circuits. The conventional precleaning circuit can process up to 1.25 tons of coal per hour. First, the $0.6 \mathrm{~mm} \times 0$ fine coal is removed via wet screening, and the remaining $6 \mathrm{~mm} \times 0.6 \mathrm{~mm}$ coal is sent to either one or two slages of cleaning using 150-mm diameter dense-medium cyclones. The cleaned coal and/or fines can be (1) used in the emerging lechnology area, (2) shipped without additional processing, or (3) first comminuted in a three-stage circuit capable of handling 100 to 500 pounds of coal per hour. The three-stage circuit includes a hammermill and two wel-grinding ball mills and is capable of grinding the coal to as fine as $0.02 \mathrm{~mm}$ top size. A state-of-the-art computer control system will be used to configure, operate, and monitor 24 distinct flowsheet configurations, requiring a minimum of manpower.

This facility will be a national resource for coal preparation research and development that will result in extensive interactions with major industrial concerns through cooperative agreements.

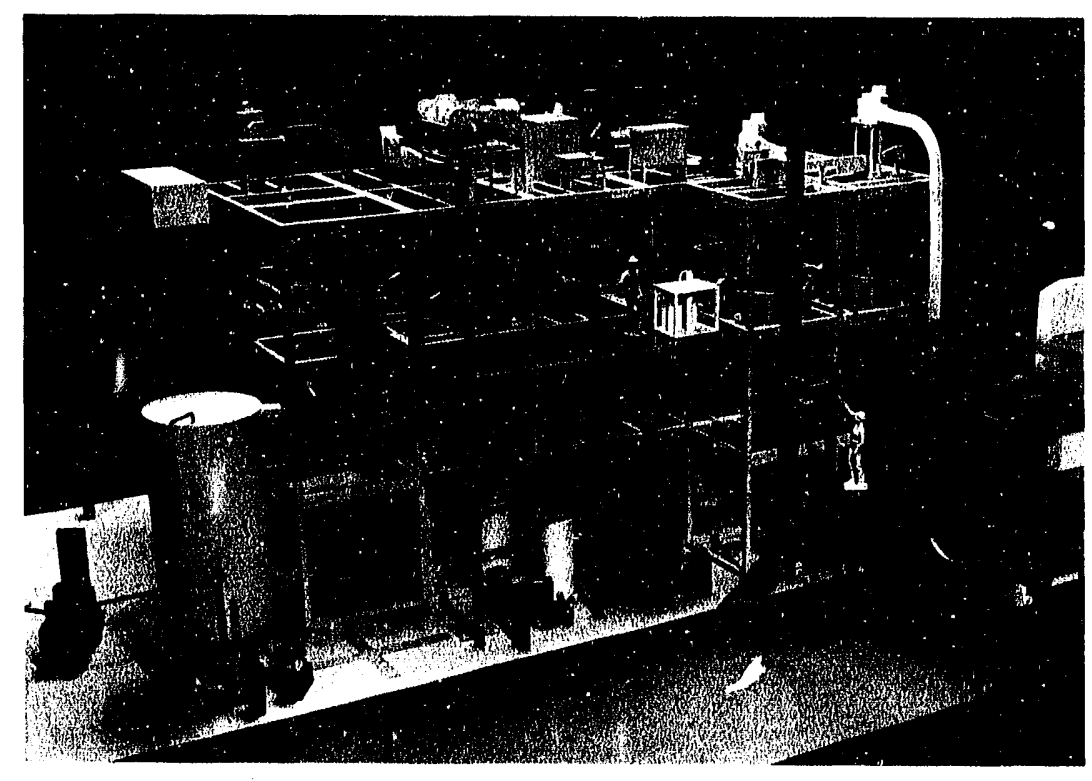

Model of new Coal Preparation Process Research Facility 


\section{Advanced Wall-Fired Low- $\mathrm{NO}_{\mathrm{x}}$ Combustion Demonstration Achieves Preliminary AOFA Test Results}

Throo advanced combustion lochnigues to reduco nitrogen oxides (NO) omissions ano being domonstrated on a 50()-MWo wall-fired boiler under tho U.S. Dopartment of Enorgy's Clean Coal T'echnology Program al (ioorgia Power's Planl Hammond. 'l'ho primary objectivo of the project is 10 demonstrald the $\mathrm{NO}$. reduction offectivoness

$\mathrm{NO}_{\mathrm{x}}$ Emission preliminary test results

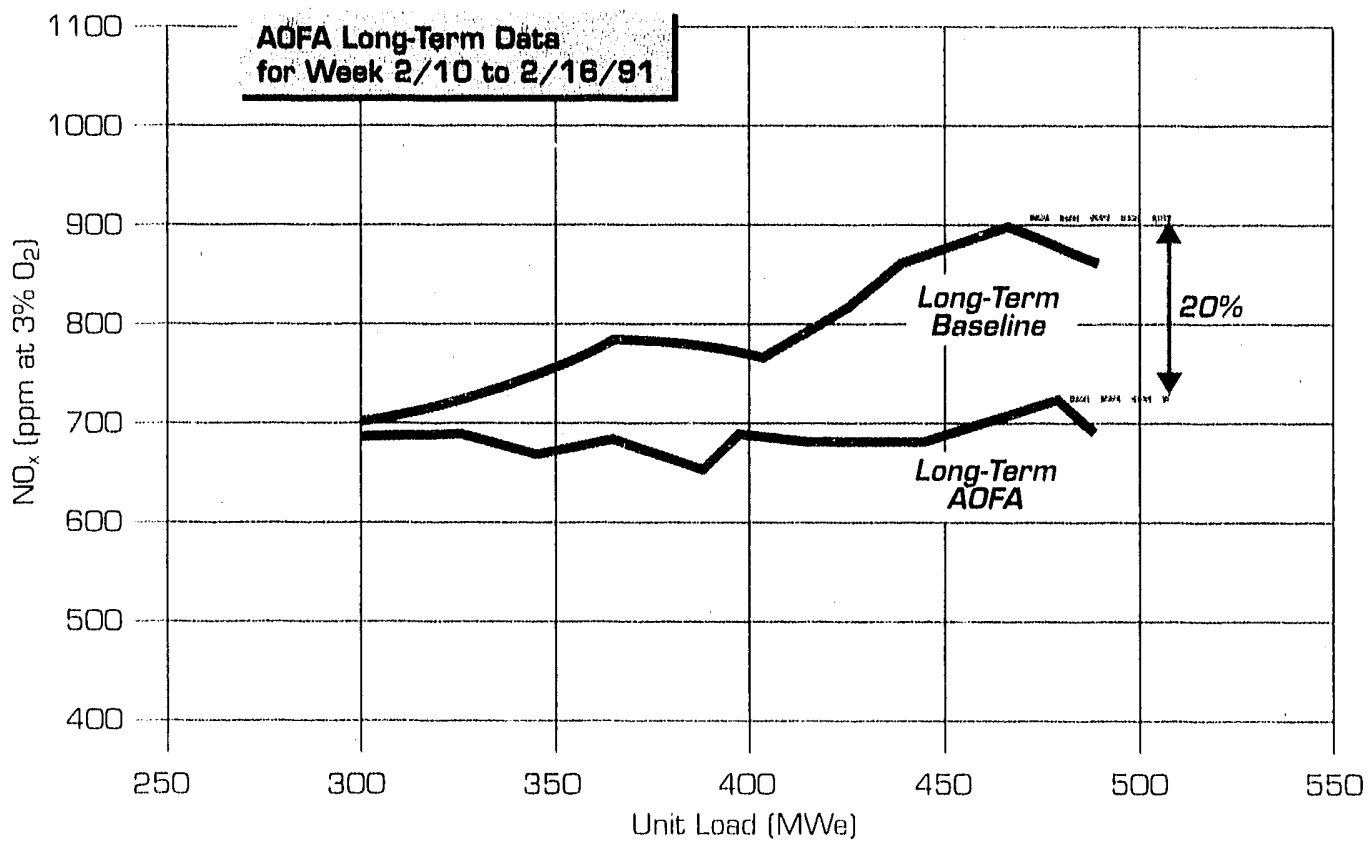
of these tochnologios under short-torm combrollod and longform ulility load dispalch conditions. 'l'heproject involves four losl ovalualions: basoline, $A O l i \wedge$, LNB, and liNB with $\Lambda()^{\wedge} \wedge$. Aftor ostablishing basolino performanco, oach technology will ho ovaluated for $\mathrm{NO}$ x reduction efferliveness and ils impant on boiler oporalion.

Basolino losts of the nonmodiliod boiler and AOFA lesting have been comploled. I.NIBs (24) have roconlly boon installod, and dala collocion began in June. Proliminary results indicale that the most important variables that alfesat $\mathrm{NO}_{x}$ reduction are boiler load and excess oxygen levels. fior $\Lambda O F \wedge$, depending upon load, the long-term preliminary lest results produced a slatistically reliable data sel thal indicates aboul $20 \%$ reduction in $\mathrm{NO})_{x}$.

$\triangle O F \wedge$ lest results also indicate incroased carbon levols in the ash altor combustion. In some cases, I wo-fold increases were observed. Southem Company Services (Soulherm Company's engineering and service company and the industrial manager for this project) is in the process of trying lo understand the reason(s) for the increased carbon levels and the impact they may have on operations.

AOFA incorporates separate (frem the wind box) in jestion ports and duct configuralions

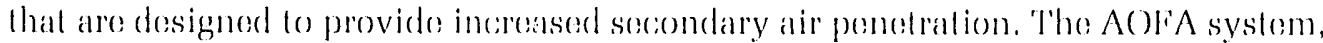
designed by foster Whoeler, provides increased penotralion velocilies, rolative to standard AOFA systems, by supplying secondary air from completely separate? aerodynamiablly designed ducts localded above the oxisting burnor wind box.

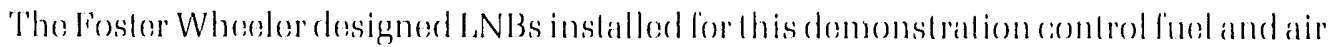

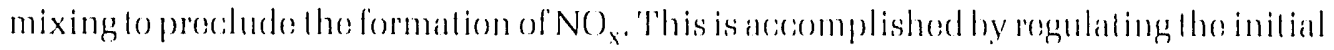

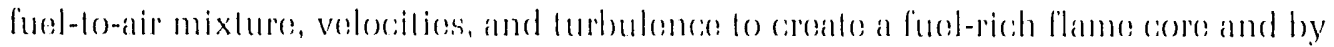
controlling the mo al which additional air, mequired locomplobecombustion, is mixed wilh flamo solids and gases lo maintain a deficioncy in oxygen. 
The Electric Power Rosearch Institule is participating in this projoct with DOE and Southern Company Services. Consistent with the goals of the National Energy Strategy, this demonstration is a joint government and industry partnership that is designed to encourage the use of U.S. domestic coals in an environmentally responsible manner.

\section{Microcel Microbubble Column Flotation}

A microbubble column flotalion lechnology called Microce ${ }^{(k)}$ (recently licensed to ICF Kaiser Engineers of Pillsburgh, Pennsylvania) removes mineral matter, including pyrite, from coal by passing very fine air bubbles up through a slurry of coal mineral matter ind water in a column. The coal particles, which are hydrophobic, attach to tho air bubbles and are carred up to the surface as a froth. At the same time, the hydrophilic mineral particles remain in the water and flow oul the bottom of the column. A countercurrent flow of water enters the top of the column and washes entrained mineralmalter particles from the froth.

Early development of this advanced flotation technology began at PETC, and subsequent work was done at Virginia Polytechnic Institute (VPI) and State University, with support from PETC, and under the direction of Professor Roe-Hoan Yoon, director of VPI's Center for Coal and Minerals Processing. The license to Kaiser Engineers is a major stop in bringing this technology to commercial readiness.

A prototype commercial-scale column is currently undergoing lesting at Shell Mining Company's coal preparation plant in Naugaluci West Virginia. The 8-foot diameter, 27-fool-high column processes aboul 16 lons per !our of minus-100-mesh, high-ash, low-solids-concentration fine coal slurry reject material from the plant's classifying cyclones. Because this material was difficult to clean using conventional froth flotation processing, it was previously discarded, resulting in losi energy values and the accumulation of solid wastes. The Microcel ${ }^{(\mathbb{k})}$ system has been successful in achieving more than 65\% Btu (onergy) recovery from this material, while reducing the ash content of the product coal to $10-12 \%$. 


\section{DOE Selects Clean Coal IV Proposals}

On September 10, 1991, DOE's Acting Assistant Secretary for Fossil Energy, Linda G. Stuntz, announced the selection of nine projects for negotiations in Round IV of the Clean Coal Technology Program. Three Integrated Gasification Combined Cycle (IGCC) technology projects will be managed by the Morgantown Energy Technology Center. Two precombustion cleaning, two post-combustion cleaning, and two combustion technology projects will be managed by PETC. The lotal Round IV proposed project cost is $\$ 1.5$ billion of which DOE's share is $\$ 567$ million.

PETC's assignments incilude projects by:

- Union Carbide Corporation to demonstrate a 75-MWe regenerable, amine-based flue gas desulfurization system at the Alcoa Generating Corporation Warrick Power Plant near Newburgh, Indiana.

- New York State Electric \& Gas Corporation to demonstrate the "S-H-U" flue gas desulfurization process at the Milliken Station in Lansing, New York. The process uses a formic acid-enhanced, wet limestone scrubber technology that claims a $98 \%$ $\mathrm{SO}_{2}$ removal rate. The project will also test the $\mathrm{NO}_{\mathrm{x}}$ OUT injection process for $\mathrm{NO}_{\mathrm{x}}$ control, and a heat pipe air heater system to optimize thermal efficiency.

- Custom Coals International to demonstrate an advanced physical coal cleaning technology and its integration with coal/sorbent reconstitution techniques to produce a self-scrubbing fuel that emits less than $1.2 \mathrm{lb}$ of $\mathrm{SO}_{2}$ per million Btu. The fuel will be manufactured at Duquesne Light's coal cleaning facility, and tests of the product will be conducted at their Cheswick Plant and at Richmond Power and Light's Whitewater Valley station.

- ThermoChem, Inc., to demonstrate the operation of a pulse combustor in an application for steam gasification of coal at a Weyerhaeuser Paper Mill in Springfield, Oregon.

- Cordero Mining Company to demonstrate the Carbontech Syncoal Process to upgrade high-moisture, low-,ulfur, low-rank coals. This two-stage, hot oil/hot air, coal drying process will be demonstrated at the Cordero Mine near Gillette, Wyoming.

- Tennessee Valley Authority to demonstrate the reduction of $\mathrm{NO}_{\mathrm{x}}$ emissions by the retrofit of coal reburning to a pulverized coal wall-fired boiler on an existing $17 \mathrm{~F}$ MWe, wall-fired unit at 'T'VA's Shawnee Fossil Plant near Paducah, Kentucky. Tl. reburn fuel will be used at micronized size, about $80 \%$ below 325 mesh.

There are now 42 active projects in the Clean Coal Technology Program approaching a total value of $\$ 4.6$ billion of which DOE's share is about $\$ 1.7$ billion. 


\section{Southern Company Services to Test Selective Catalytic Reduction Technology}

In this \$15.6-million elfort, Southern Company Services, Inc., the U.S. Department of Energy, and the Electric Power Research Institule (EPRI) will test Seloctive Catalytic Reduction (SCR) technology on Gull Power Company's Planl Crist Unit No. 5 located near Pensacola, Florida. This project will demonstrate the applicability of the SCR technology to significantly reduce nitrogen oxides $\left(\mathrm{NO}_{x}\right)$ emissions from power plants
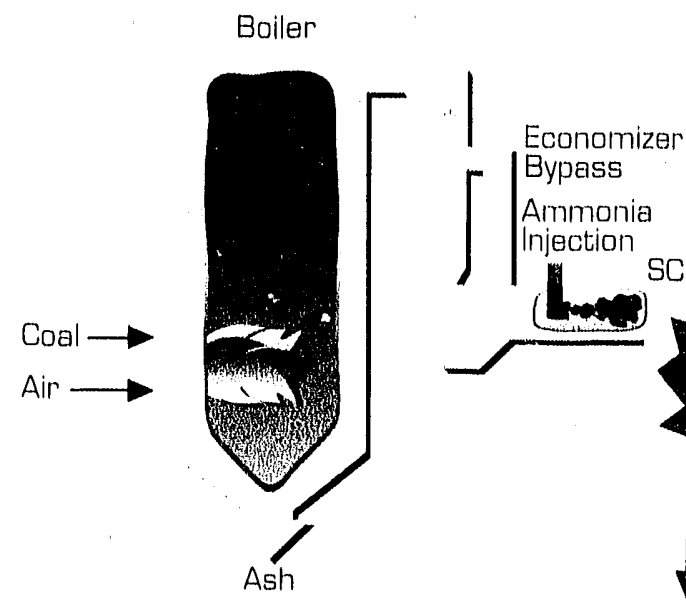
using flue gas that contains high- and low-ash loadings derived from the combustion of high-sulfur U.S. coals. SCR process capabilities (NO) removal catalyst performance, operating conditions, calalyst life, etc.) and process economics will be assessed.

In the SCR system, contro!led amounts of ammonia are mixed with the combustion gases produced from coal combustion. The mixture then passes through a reaction chamber, containing catalyst, buill alongside the boiler. Tho calalyst promotes the reaction of $\mathrm{NO}_{\mathrm{x}}$ with ammonia to form harmless molecular nitrogon and water. The SCR facility will consist of three 2.5-MWe-equivalent SCR reactors, six 0.20-MWeequivalent SCR reactors, and associated equipment for operations, maintonance, and testing. 'The testing will be conducted on a flue gas slip stroam taken from Unil No, 5.

This project will test various catalysts of ciifferent shapes and chemical compositions. Three U.S. catalyst suppliers (Engelhard, Grace, and Norton), I wo Europoan suppliers (Haldor Topsoe and Siemens), and lwo Japanese suppliers (Hilachi Zoson and Nippon Shokubai) have been chosen to supply catalysts for this Cilean Coal Techmology Program demonstration project.

The project's preliminary design phase is complete, and the detailed engineering phase has begun. If successful, this project will demonstrate that SCR can achieves approximately an $80 \%$ reduction of $\mathrm{NO}$ x emissions from ulility boilers firing highsulfur, U.S. coals with acceptable calalyst deactivalion rates. 'I'his texhnology, which is being lested on a langentially fired boiler during this demonstration, could be retrofitted onto other types of boilers, including cyclone-fired boilers-atypos fooiler that is particularly prone to high $\mathrm{NO}_{\mathrm{x}}$ emissions and that cammol bo easily retrofillod with olher developing $\mathrm{NO}_{\mathrm{x}}$ control lechnologies.

DOE is providing $\$ 7.5$ million, or $48 \%$, of the project's total cost. Eillel is contributing $\$ 2.0$ million, and Southern Company Services, Ince, is providing more than $\$(0,0)$ million. The project is scheduled to be completed by mid-1994.
Southern Company Services Selective Catalytic Reduction [SCR]

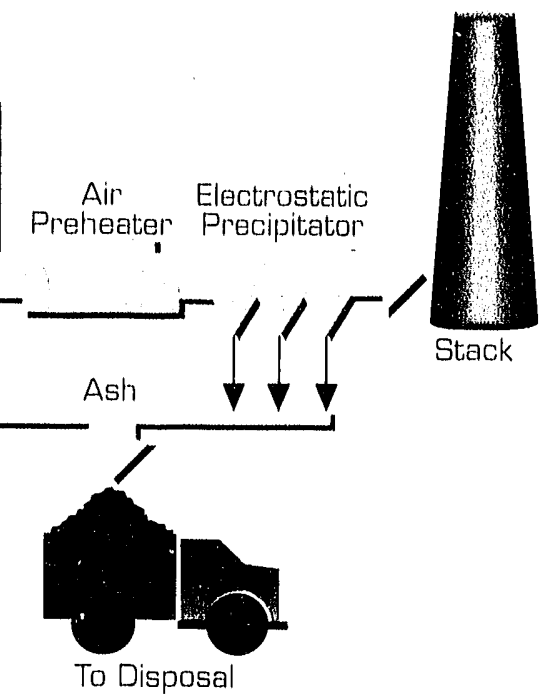




\section{RD\&D AWARDS}

Rosearch, Dovolopmenl, and Domonstration (RD \& D) Awards aro awardod by PlitC as (1) granls lo universities, (2) contracis lo corporalions, or (3) cloan conl cooporallva agreomonts with industry. 'They support key sciontilic and enginoering projocis identified by Plél'C as vilal lo lho nation's onergy intorest. For reports rosulting from these contracis, ploaso conlact oflhor:

(1) for DOE employees and its contraciors

Office of Sciontilic \& 'Tochnical Information

P.O. Box 62

Oak Riclge, TN 3783'1

(615) $576-8401$
(2) the gonomat public:

Nalional Tochnical Informalion Servico U.S. Department of Commerce 5285 Porl Royal Roarl Springlield, VA 22161 (703) $487-4650$

Please be aware that there are fees connectod with these services.

\section{Date of Award}

Awardee

\section{Project/Contract Number}

\section{Liquid Fuels}

$01 / 15 / 91$

$02 / 08 / 91$

$03 / 15 / 91$

$04 / 02 / 91$

$05 / 16 / 91$

$(05 / 21 / 91$
Universily of Arkansas

Fayelleville, AR

Univorsal Fuol

Dovolopment Associalion

Grand Forks, ND)

UOP lne:

Corporate Research Center

Des Plaines, 11.

Advanced Fuol Rosearch Basl Hartford, C."]

M. W. Kollogg Co. Houston, 'TX

Amocosole Co. Napervillo, II.
High Pressure Syngas Formentation AC22-91PC91028

Fine Purticle Catalysis for Coal Licpuefaction AC'22-91PC90048

Development of a Cialalyst for Conversion of Syngas Derived Malorials to Isobutylone AC:22-91PCOOO)

Dual Rolo of Oxygen Functions in Coal Prolroatmont and Jiguelacilion: Crosslinking and Cloavago Roancitons

AC:22-91PCO1026

Design of Ceneric Coal Conversion Facility ACi22-91PCi83854

Solective Calalylic: Colacking of fischor-'ropscoh Licpuid lo High Valuo Transportalion Fuols AC'22-91PCOCO)57 


\section{Date of Award}

Awardee

Project/Contract Number

$06 / 27 / 91$

Unton Carbido Corp.

Charleston, WV

Holorogononus Catalylla Procoss

for Alcohol puobs from Syngas

ACi22-9) $1 \mathrm{PC}(\mathrm{c})(0) 46$

\begin{tabular}{|c|c|}
\hline \multicolumn{2}{|c|}{ linvirommenlal Conleol lecehnology } \\
\hline $05 / 23 / 91$ & $\begin{array}{l}\text { Consolidation Coal } \\
\text { Research Division } \\
\text { Piltsburgh, PA }\end{array}$ \\
\hline $06 /(04 / 91$ & $\begin{array}{l}\text { Soulhern Resenrch } \\
\text { Instilulo } \\
\text { Birmingham, } \mathrm{Al} \text {. }\end{array}$ \\
\hline $06 / 06 / 91$ & $\begin{array}{l}\text { Southorn Rosoarch } \\
\text { Institulo } \\
\text { Bimmingham, } \mathrm{Al} .\end{array}$ \\
\hline
\end{tabular}

Advanciod ln-Ducil Injection lor Bi( )

$\Lambda(22-9) 1 P(4)(136)$

A Novol Canbon-Basod Procoss for

Fluo (ias Ciloamup)

$\Lambda(22-1)+P(3) 1345$

Fundamonlal Mochanisms in liluo

Gas Condilioning

AC22-01PC90365

\section{Small Business Innovation Research (SBIR) Program}

DOE's SBIR program was doveloped to implement the Small Business Innovation Dovelopmonl Aot of 1982. 'The objective of tho program is to strengthen the role of small, innovalive firms in areas of research and development thal are federally funded. 'This rosearch and devolopment, in lurn, will sorve as a base for tochnological innovation while al tho samo limo meeling agency noods.

In 1990, under Phase I of the SBIR program, 170 projects woro fundod (out of 1,172 glanl applicalions submitled) at about $\$ 50,000$ each lor preliminary feasibility studios. Tho firms rocoiving lhoso Phaso 1 awards were eligible to submil applications to conlinuo thoir work in 1991 under Phaso 11 of tho program, which is the principal research and development phase. A list of some of tho applicalions recommended for Fiscal Yoar 1991 Phaso 11 awards is givon bolow. Theso Phaso ll awards will average about $\$ 495,000$ for a i wo 0 -year period.

lior a complete list of the 65 applicalions recommended for liscal Yoar 1991 Phase Il awards, conlan:l Dr. Samuel Barish, SBIR Program Managor, U.S. Departmont of Enorgy, ER-16, Washinglon, I) 20545. The Deparment expects to issue tho next SBIR solicilation in the fall of 1991. If you wish to be on the list to receive the noxt program solicitation, submit your roguest lo Dr. Barish al tho above addross or vall $301-353-3054$.

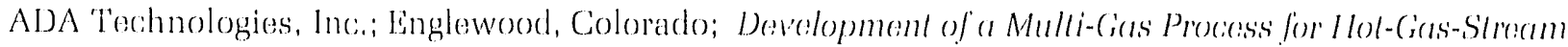
Clocmup Sirstems.

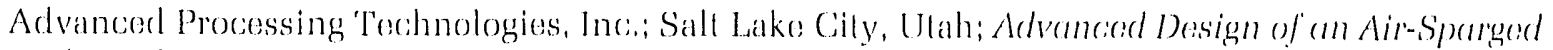
Hydrocyctone System for Fine Coal filotalion.

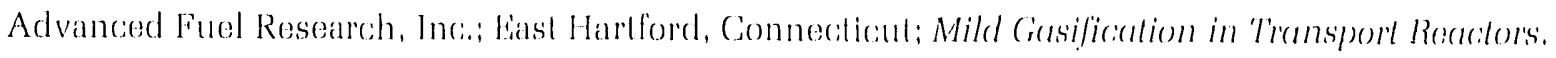

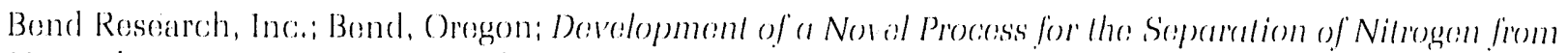
Natural Cias Using a Nitrogen Solvent.

CeraMem Corporation; Wallham, Massachusells; A Novel Fillor Shape for Flue Gers Cilermup. 


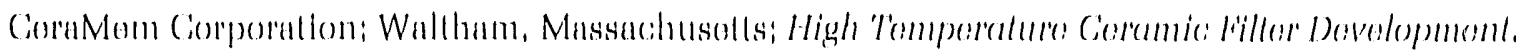

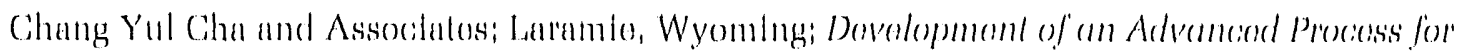

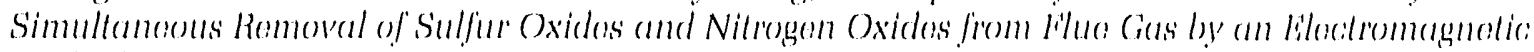
Molhod.

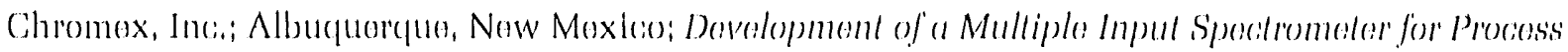
Monitoring Applications.

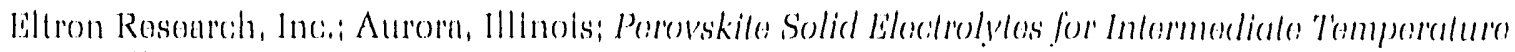
litul Ciells.

Giner, Inca: Wallham, Massachusolls; Devolopment of a Flue Gas Desulfurizalion Procosss Using a Novel Regeneralive Hydrogen Bromide System.

Mombrane 'lochnology \& Research, Inc.; Menlo Park, California; Ultrathin Melcul Membranes,

Norlhwost Fuel Devolopmont, Inc.; Portland, Orogoni Gas T'urbines for Combustion of Nalural Geas in Mino: Vonlilalion Air.

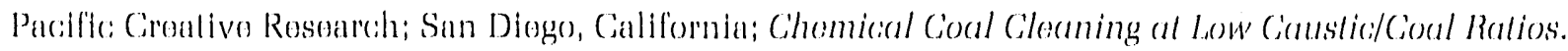

Poak Instrumonts, Inci, Penninglon, Now Jorsoy; An Efficient X-Ray Wavolength Spectromater for Improved Lilemental Analysis on Eilectron Microsciopes.

Southwest Scionces, Inc,; Santo Fo, Now Moxico; A Novel Mass Spocilromeler for Combustion Studies,

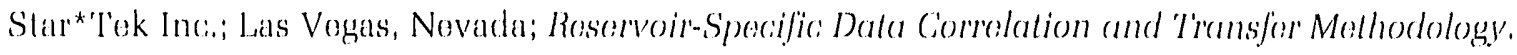

TDA Research, Inc.; Wheal Ridge, Colorado; High Tomperalure Hydrogen Sulfide Removal. 


\section{Publications and Presentations}

\section{Ciocal Prepocrercion}

Sulfur and Ash Reduction Potential and Selected Chomical and Physical Properties of U.S. Coals, Volume II-Central Region.

Cavallaro, J.A., Deurbrouck, A.W., Killmeyer, R,P., Jacobsen, P.S., and Fiuchs, W.

USDOE/Pillsburgh Energy Technology Conler, DOE/PETC/TR-91/1, Ocilober 1990.

Sulfur and Ash Reduction Potential and Selected Chemical and Physical Properties of U.S. Coals, Volume III-Western Region.

Cavallaro, J.A., Deurbrouck, A.W., Killmeyer, R.P., Jacobsen, P.S., and Fuchs, W.

USDOE/Pittsburgh Energy Technology Conter,

DOE/PETC/TR-91/2, October 1990.

\section{Advanced Coal Cleaning-An Environmental Control Technology. \\ Feeley, IIl, T.J. \\ 1991 Southeast Mining Institule Conferencie, May 22-24, 1991, Tuscialoosa, Alabama. \\ (Presentation only, no manuscript.)}

\section{Surface Modification of Oxidized Coal by}

Methanol Vapor.

Gray, M.L., Lai, R.W., and Wells, A.W.

Preprints, Div, Fuel, Chem., Am. Chom.

Soc., 36(2), 804-813, 1991.

Initial Study of Dry Ultrafine Coal

Beneficiation Utilizing Triboelectric Charging with Subsequere Electrostatic Separation.

Link, T., Killmeyer, R., Elstrodt, R., and Haden, N. USDOE/Pittsburgh Energy T'echnology Centor,

DOE/PETC/TR-90/11, Ocitober 1990.

Selection and Production of Medium Solids for the Micro-Mag Process.

Miller, K.J., Klima, M.S., and Killmeyer, R.P. USDOE/Pittsburgh Enorgy Tochnology Center, DOE/PETC/TR-91/5, May 1991.

\section{Clean Coal l'achnology}

Innovative Coal Gas Cleaning at Sparrows Point Coal Chemical Plant, Maryland for Bothlehem Steel Corporation. Anlrobus, K., Plalts, M., Barbold, L.M., and Kornosky, R. M.

Joinl ASME/IEEE Inl'l Power Generalion

Conforence, October 21-25, 1990,

Boston, Massachusolls.

Development and Testing of the NOXSO Flue Gas Cleaning System.

Coflïn, B.D., Elia, G.G., Noal, L.G., Strakey, J.P., Brundell, C.P., Maddon, D.R., and Bolli, R.E. Joint ASME/IEEE Int'l Powor Goneralion Conference, October 21-25, 1990,

Boston, Massachusells.

Efficiency of the WSA-SNOX System for Reducing $\mathrm{SO}_{2}$ and $\mathrm{NO}_{\boldsymbol{x}}$.

Collins, D.A., and Evans, R.J.

"Engineering Foundation Conference,

Environmental and Economic: Impacts of Coal

Utilization," January 20-25, 1991,

Santa Barbara, California.

Status of the Pittsburgh Energy Technology

Center's Clean Coal Projects.

Eastman, M.L., Strakoy, J.P., Sanloro, R.R., and Ruothor, J.A.

Proceodings, 7lh Annual Inl'l Pillsburgh Coal

Conference, September 10-14, 1990,

Pillsburgh, Pennsylvania.

Cyclone Retrofit Demonstration Program with Transalta's Low $\mathrm{NO}_{x} / \mathrm{SO}_{\mathrm{x}}$ Burner.

Elia, G.G., and Frasor, W.L.

Joint ASME/IEEES Inl'l Power Genoralion

Conference, Octobor 21 -25, 1990 ,

Boston, Massachuselts.

Combined $\mathrm{SO}_{2} / \mathrm{NO}_{x}$ Flue Gas Cleaning Technologies in the U.S. DOE Clean Coal Technology Program.

Elia, G., Corbett, R., and Ruothor, J.

Enginooring foundation Conforence,

"Environmontal and Eeconomic: Impatis ol cionl

Utilizalion," January 20-25, 1991.

Sanla Barbara, Califormia. (Abstracal onlyy) 
Pre-Combustion Tochnologies for Power Plant Emissions Control.

Evans, R.J., Armor, A., Row, R., and

Harrison, C.D.

World Coal Instituto Conferenco, Aprll 2-5, 1991, London, England.

Environmental and Economic Bonefits of Using Clean Coals in Ltility Botlors. Evans, R.J., Levasseur, A.A., Kohoo, D.B., and Parkinson, J.W.

Joint ASME/IEEEE Int'l Powor Genoration

Conference, Oclober 21-25, 1990,

Boston, Massachusolts.

Evaluating the Effects of Cleaned Coals on Utility Boilers.

Kehoe, D.B., Horvol, J,D., Evans, R.J, and

Levasseur, A.A.

Int'l Coal Prop. Conference, October 22-26, 1990,

Tokyo, Japan.

Demonstrating the WSA-SNOX Process through the CCT Program.

Kingston, W.H., Cunnighis, S., Evans, R, and

Speth, C.

Joinl ASME/IEEE Int'l Power Goneralion

Conference, October 21-25, 1990 ,

Boston, Massachusetts.

Coal/Oil Coprocessing Retrofit Alternatives at a HIG Conversion Refinery.

Rao, S.N., Schindler, H.D., and Bastman, M.L. Procoodings, 7th Annual Int'l Pillsburgh Coal Conference, 739-749, September 10-14, 1990, Piltsburgh, Ponnsylvania.

Pure Air Advanced Flue Gas Desulfurization System at the Bailly Generating Station.

Satrom, S., Bolinsky, F., and Sarkus, T'.

Joint ASME/IEEE Inl'l Power Goneration

Conference, Ocitober 21-25, 1990,

Boston, Massachusetls.

Innovative Clean Coal Tochnology

Demonstration of Advanced Low-NO Combustion Techniques for Wall-Fired and Corner-Fired Boilers.

Wilson, S.M., Elia, G.G., Balt, A.L., and

liskinazi, D.

Joint ASME/IEEE Int'l Powor Goneralion

Conforence, October 21-25 1990,

Boston, Massachusells.
Demonstration of Advanced Wall-Fired and Tangentially fïred Combustion Tochniques for the Reduction of Nitrogen Oxides $\left(N_{x}\right)$ Emissions from Coal-Firod Boilors. Wilson, S.M., Hardman, R.R., Filla, C.G., Baldwin, A., and liskinazi, D.

Jolnt ASMIS/IELEE Inl'| Power Gonorallon Conferonco, October 21-25 1990,

Boston, Massachusotls.

\section{Coal Combustion}

Transfer Propertios of' Ash Deposits.

Ramerr, E.R.

Contral Statos Soction, Tho Combustion

Instilute, Nashville, Tennesseo,

April 21-24, 1991.

Deposit Initiation Via Thermophoresis

Part 2: Experimental Verification of Hypothesis

Using a Simulated Suporheater Tube.

Smouse, S.M., and Wagonor, C.

Procoedings, Engineering foundalion Conference on Inorganic 'Transformations and Ash

Deposition During Combustion, 1991.

Exploring the Combustion Characteristics of Indian Coals Through the USAID-India Collaborative Coal Program.

Smouse, S.M., Ramachandra, K., and

Nandakumar, K.

Proceedings, Enginooring Foundation Conforenco on Inorganic Transformalions and Ash

Deposilion During Combustion, 1991.

Evaluation of Coal-Water Mixtures Prepared with Advanced Coal-Cleaning Products.

Wildman, D.J., Stanko, D.C., and Ekmann, J.M. Procoedings, 4th Int'l Symposium on LiquidSolid Flows, 229-233, Juno 24-27, 1991,

Porlland, Oregon.

Measuremonts of Pyrolysis Rates and Structural Changes During the Devolatization of Single Coal Particles Using Pulsed Laser Heating at Combustion Level Heat Fluxes.

Zlochowor, 1.A., Hertzberg, M., Malonoy, D.J., and Tran, P.X.

Procoedings, 7lh Annual Inl'l Piltsburgh Coal Conforences, 20-29, Soptember 10-14, 1990,

Piltshurgh, Ponnsylvania. 


\section{lilue Gias Cilocinup}

Integrated $\mathrm{NO}_{\mathrm{x}}$ Control Retrofits in

FGD Processes.

Livengood, C., and Markussem, / M.

lingheoring lioundalion Conlorencio,

"Einvironmental and Economici Imparis of Conal

Uilization," Janualy 20-25, 1091.

Sanla Barbara, California. (No manuscriple)

\section{Solids 'Transport}

A 'Theory for Granular Materials Exhibiting Normal Stress Effocts Based on Enskog's Denso Gas Theory.

Boyle, Es.., and Massoudi, M.

International fournal of lingineoring scionece.

288: $1261-1275,19090$.

Modeling of Confined, Dilute,

Particile-Laden, Turbulent, Coaxial Jets, Part II: Model Variation.

Fuchs, W., and Rizk, M.A.

7th Annual Inl'l Pillsburgh Coul Conloronce,

Soplember 10-14, 1990, Pllsburgh,

Ponnsylvania.

Heat Transfer and Flow of a Modilied Second Grade Fluid.

Gupla, G., and Massoudi, M.

1991 National Heal Transfor Conference,

Tochnical Sossion on Fundamontals of Heat

'l'ransler in Non-Nowlonian Flow,

July 26-31, 1991, Minneapolis, Minnesola.

Turbulence Modelling of the Flow Field in Combustors Using the Non-Linear k-e Model. Hwang, C,C., Zhu, G., Massoudi, M., and likmann, J.M.

In Advances in Numarical Simulation of

Turbulent l'lows, ASMLE FED, Vol, 117, 35-42,

1991.

Couette Flow of a Fluid with Entrained Solid Particies.

Johnson, (i., Massoudi, M., and Rajagopal, K.R. In Recent Advencess in Mechanicis of Structured Conlinulu, ASMle AMD, Vol, 117, (17-105 1991.

\section{Flow of a Filuid-Solid Mixture Between}

\section{Flat Plates.}

Johnson, (j., Massoudi, M., and Raljigopal, K.R. Chomical Enginouring Solonce, 46 ,

$1713-1723,1991$.
A Roviow of Intoraction Mochanisms in l'luidSolid Flows.

Johunson, (i., Massoudd, M., und Rulagounal, K.R.

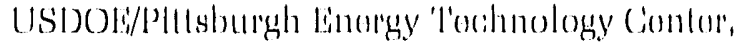

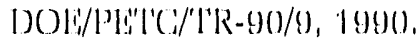

Modolling of' Solid Particles in F'tuddizod Bods. Massoudli, M., and Boylo, li.J.

Mallomalical and Compular Moclolling, 14, $785-789,19900$

Modification of the 'IEACH Computor Codo for' Uso in a Study of' Swirling 'Turbulent Flows.

Massoudl, M., likmann, J.M., Hwang, (., C.. and 'Zhu, G.

U.S.DOE/Pillsburgh linorgy 'I'ochnology Conlesr, DOL/PE"L'CL/L'R-91/3, 1991.

Natural Convection Flow of a Non-Newtonian Fluid Botween Two Concentric Vertical

Cylindors.

Massoudl, M., and Christio, I.

Acta Mochanica, 82, 11-19, 1990.

Overview of Pneumatic Transport Resecarch at PETC/U.S. DOE.

Mathur, M.P., Shafler, li.D., Wildman, D.,

Chitester, D.C., Massoudli, M., and

Klinzing, Gili.

Procoedings, Pnoumatech 4, 4h Inl'l Conforenco on Pneumalic Conveying Tochnology,

June 26i-28, 1990, Glasgow, Scolland, U.K.

Modeling of Confined, Dilute, Particle-Laden, Turbulent, Coaxial Jets, Part I: Model

Formulation.

Rizk, M.A., and l'uchs, W.

7lh Annual Inl'l Pillsburgh Coal Conferenco,

Soptember 10-14, 1990,

Piltsburgh, Pennsylvania.

\section{Magnelohydrodynamics}

An Overview of the Department of Lnergy's MHD Program.

Chambers, H,I', Jr, and Owens, W.R.

29th Aorospace Scioncos Mooting, January 7-10, 1991, Rono, Novala.

Update on DOE-MHD Program.

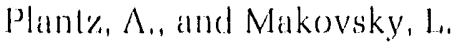

IAP'; Nuclour/MH-H) Working ('iroup),

May 22-23, 1991, Cainessullo, lilorida. 
Advancied Llocitrici Puwor Using

Magnotoliydrodynambis - $\Lambda$ Sturvoy of llao U,S. DOE MHI) Program,

'I'lomilels, (i.A.

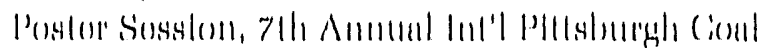

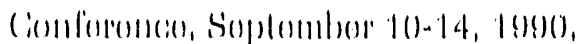

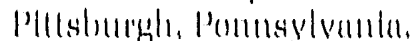

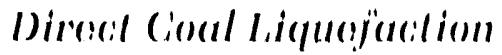

Disporsod Caltulysts in Coonl Liqualiacilon.

Buckmilh, B, (i.

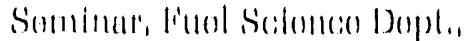

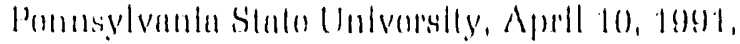

Slalo Cinlloga, P'omnsylvanla,

\section{Integration of Cool Liquefaction and Coal} Beneficiation.

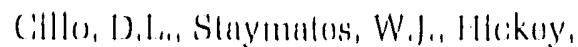

R.R., l,al, R,W., losulls, $\Lambda, V_{\text {. }}$ and

Killmoyelr, R.l'.

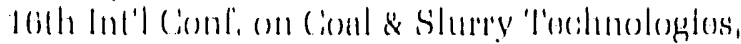

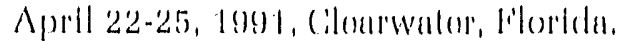

Effect of Activation Conditions on

Disporsed Iron Catalysts in Coal Liquofaction.

('ughnl, A.V., UM, B.R., Kristman, D., and

Hicikuy, R,li.

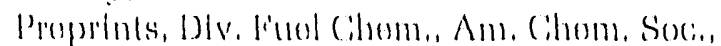
36(1), $191-102,1991$.

Carbon Blacks as Catalysts for Soloctivo

Carbon-Carbon Bonds Cloavago.

linraisla, M.

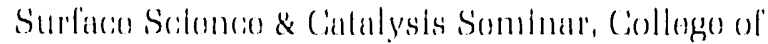
Chomislry, Universily of Callfornla al Borkoloy,

Novombur 24, 1990, Borkoloy, Callilornita.

Coal Blacks as Calalysts for Synthetic Fuels.

linrcastu, M.

(GNFAB Moollng, August 9-10, 1900,

l.arimin, Wyoming.

DOLi-Advanced Research Liquofaction Program. finciasiu, M.

(C)NIAB Monlling, August 9-10, 1990,

laramio, Wyoming.

Fine Particle Sizo Iron Based Catalysts:

An Overview.

linriasiu, M.

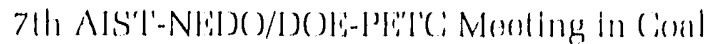

licpuetiation, ()elober 10, 19900,

Now ()ploans, loulisiana.

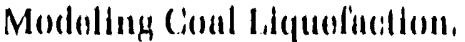

1. Dociomposillion of' 4-(1-Naphlhylmothyl) Bibmayl Calalyand by Cianbon Black.

linl'cinslu, M, anil Simllli, (i.

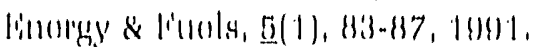

A Highly Activo Desposablo Iron Calalyst lion coul Licyustacition.

lllokuy, R.li,

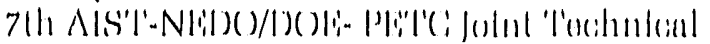

Mooullag, Nov, 12-10, 10680,

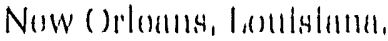

Slurry Bubble (oolumm (Oporation will Multicomponent liquid Mixtures Having fouming Capacity,

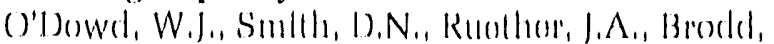
(i, Ii, and sinllh, D, Il,

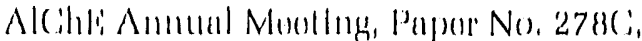

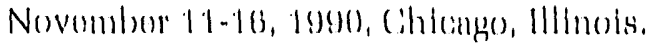

Protroatmont for Coal Liquadiation.

Pollack, N.R., Holdor, (i.D), and War\%inskl, R.P.

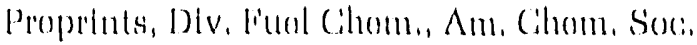

$30(1), 15-22,160) 1$.

Dispersod-Phase Calalysis in Coal

Licyutefaction.

U1\%, B.R., Cugini, A.V., and lirommoll, ki, A.

Ac'S symposium Soriess No, 437, Novel

Maleriols in Holorogemous Cialulysis, Baker, R.'I', and Murroll, L..., (ods.), Chap, 27, 2839-299, Am. Chom, Sori, Washinglom, 1) i, 1990).

Morphology and Liquofiation Characteristics of' Pyridine-lixtracted Illinois No, 6 Coal.

War\%lnskl, R.P., and Holdor, (i, D.

Proporints, Div, l'uol cihom,, Am, Chom. Soxi, 36(1), 44-52, 19691.

\section{Indirecel Licfureforelion}

Status of PE"I'C's Mothane-to-Higher Hydrocarbon Procoss.

'l'aylor, C.E., Nocoll, R.P., Whilo, C.M., Mad donald, M.A., Andorson, R.R., and Marlollo, D,V.

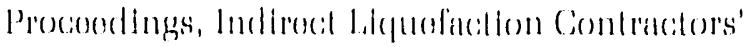
Roviow Mooting, 30)-58,

Sophombor 1990, Pillshorgh, Ponnsylvanla. 


\section{Biological Procosssing of Cool}

Bloruactor stady of' tho Micirobial Dogradation of' l,ow-Rank Couls,

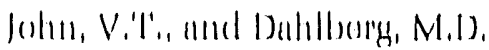

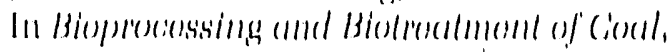

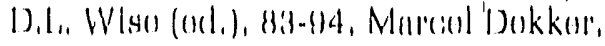

Now York, loge(1.

\section{Anclylical Molhods}

An licomomic: Cirystal Rotalion Desvico for Polarizod Light Micirosciopy.

Besolure, H. B.

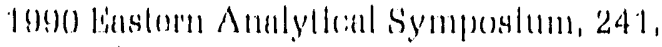

Novamber 12-16, Somoreal, New Jorsoy.

'T'amperature Dependence of the Electron

Paramagnotic Resonance Intensity of Whole

Couls: 'Ihos Sourch for 'Irriplet States.

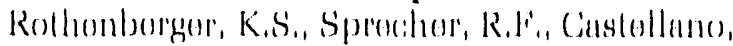
S.M., and Relcolfsky, H.L.

Advancios in Chomblery Sorlos 2229, 'T'ochulquess

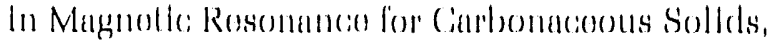
Amorican Chomicanl Sostoly, loge1.

\section{Inlernalional Acolivilies}

\section{Indo-U.S. Collaborativo Projects in Coal}

Conversion 'tochnology.

Jhirad, D.J., Padmanaban, \&., Potors,

W.C., and Kilshman, R.P.

Finginooring fioundation Conleoroncos,

"linvironmental and liconomic: Impacts of Conl

Unilgallon," fantuny 2(1)-25, 10)91,

Santa Barberra, Cinliformb. 


\section{WORKSHOP NOTES}

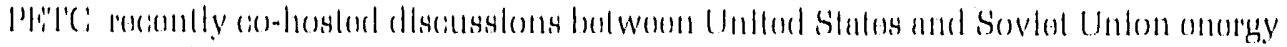

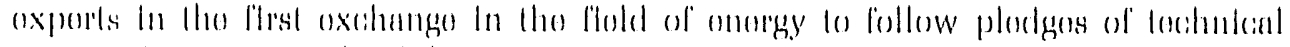

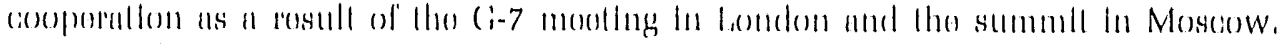

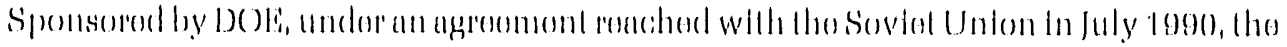

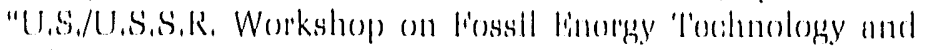

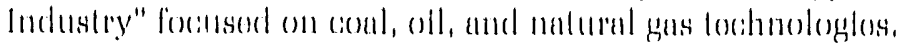

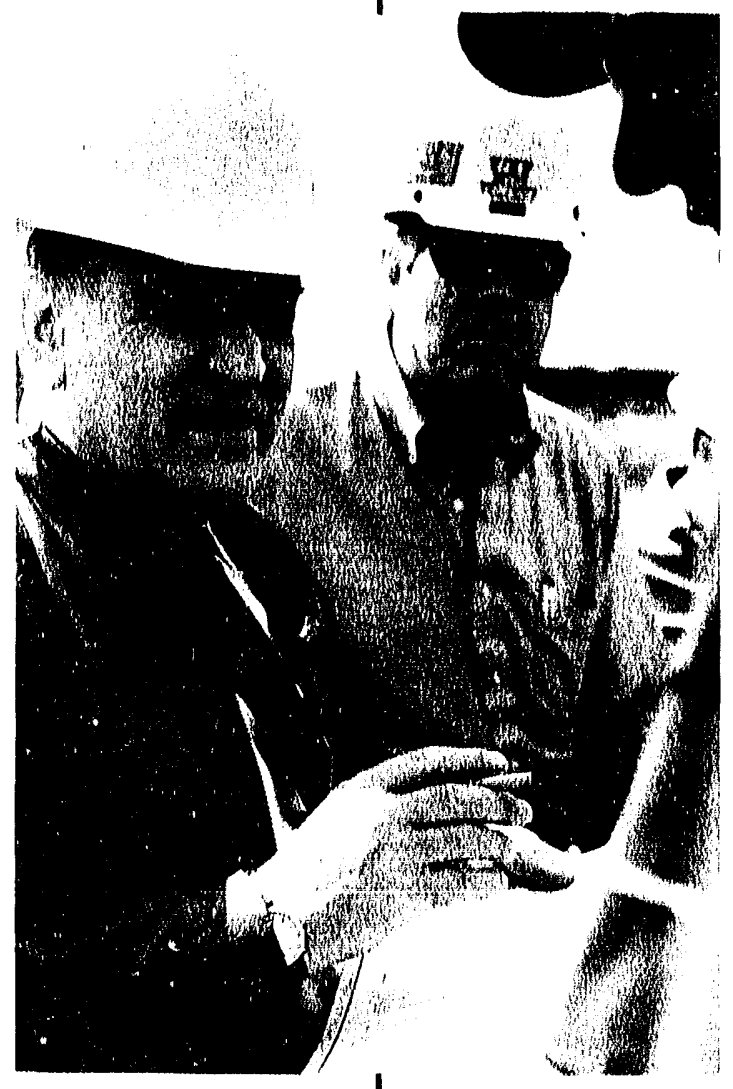

'l'hou workshop longun in Morganlown, Wosl Virginla, on July

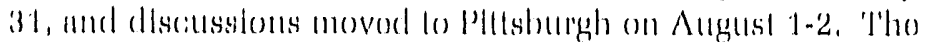

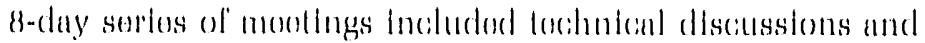

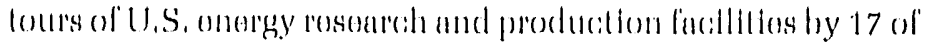

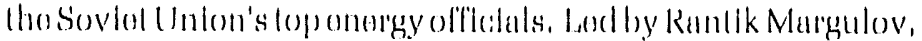

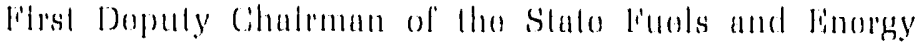

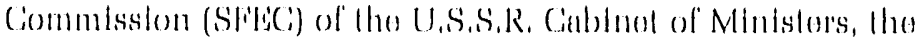

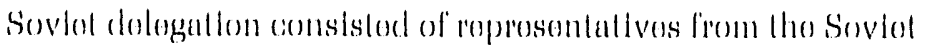

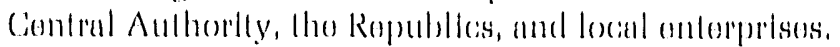

'l'he workshop concluelod on August 7 when a reciorel of tho moseling was stgnesl by Margulov and the hoad of tho Unlled Slates delogation, DOS: Dopuly Sucretary W. Honson Moore.

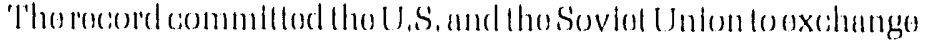
Information on onergy pollicy and ditrestions and world onergy issuess. In addilion, the workshop met a socond lmportant objectiva - it estiblishod a commil monl bol woon govornment

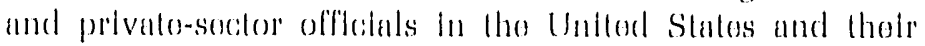
counterparts in tho U.S.S.R. Io hold lochnology exchanges to advancio officionl and onvironmentally salo dovolopmonts in the fossil enorgy fledel.

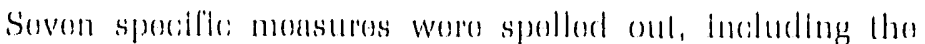

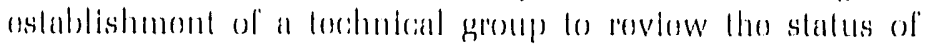
magnotohydrodynamitis (MIII)) tochnology and to dovolop

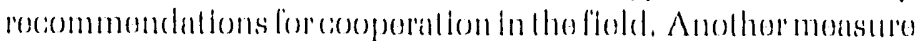

Mikhail Shchadov (left), Soviet Minister of the Ministry of the Coal Industry, was impressed with the surface mine production at the REF Coal Company in Cadiz, Ohio. Jack Cox President, of R\&F (pictured in background), provided extensive cletails of R\&F's spoil-side clragline used at this mine site. Environmential controls and reclamation practices were of greal; interest: to the Soviet delegation.

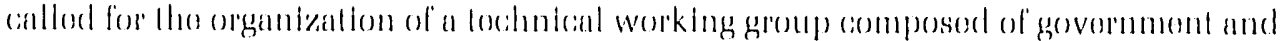

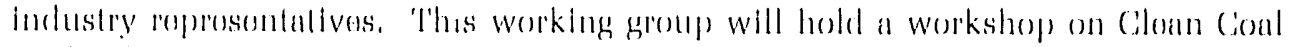

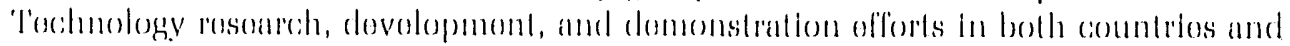

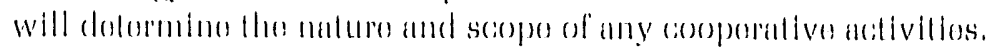

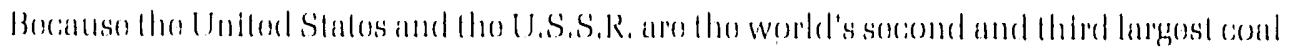

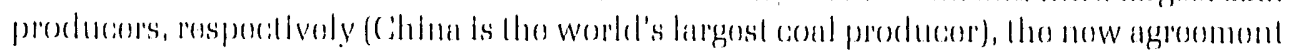

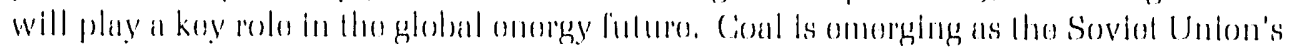

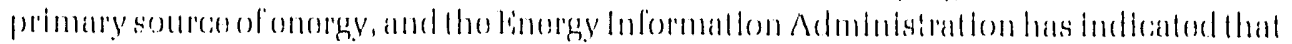

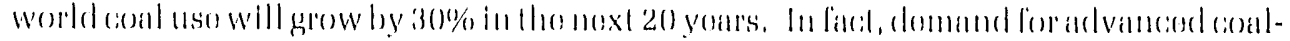

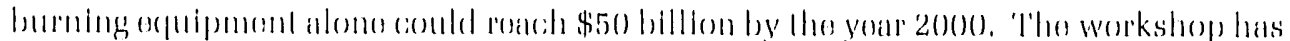

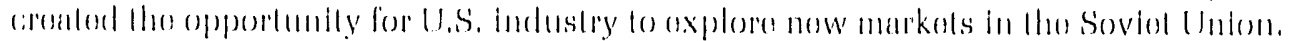

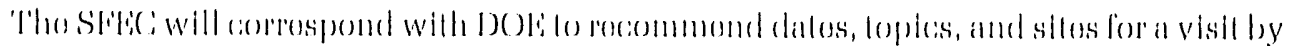

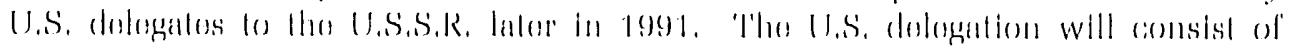

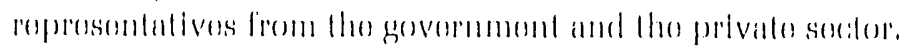




\section{CALENDAR OF UPCOMING EvENTS}

December 3-6, 1991

April 28 - May 1, 1992

May 4-7, 1992

July 26-31, 1992

September 22-24, 1992
$1991 \mathrm{SO}_{2}$ Control Symposium

Co-sponsors: EPRI \& U.S. EPA

Grand Hyatt Washington, Washington, DC;

Coniract: C. J. Drummond (412) 892-4889

17th International Conference on Coal Utilization \& Slurry Technologies

Co-sponsor: Coal \& Slurry Technology Association

Sheraton Sand Key, Clearwater, Florida

Contact: L. A. Ruth (412) 892-4461

3rd International Symposium on the Biological Processing of Coal

Co-sponsor: EPRI

Sheraton Sand Key, Clearwater, Florida

Contact: G. Olson (412) 892-6294

Coal Preparation, Utilization, and Environmental Control Conference

Westin William Ponn, Pittsburgh, Pennsylvania

Contact: R. E. Hucko (412) 892-6133

\section{Liquefaction Contractors' Review}

Westin William Penn, Pittsburgh, Pennsylvania

Contact: G. V. MoGurl (412) 892-4462 
7
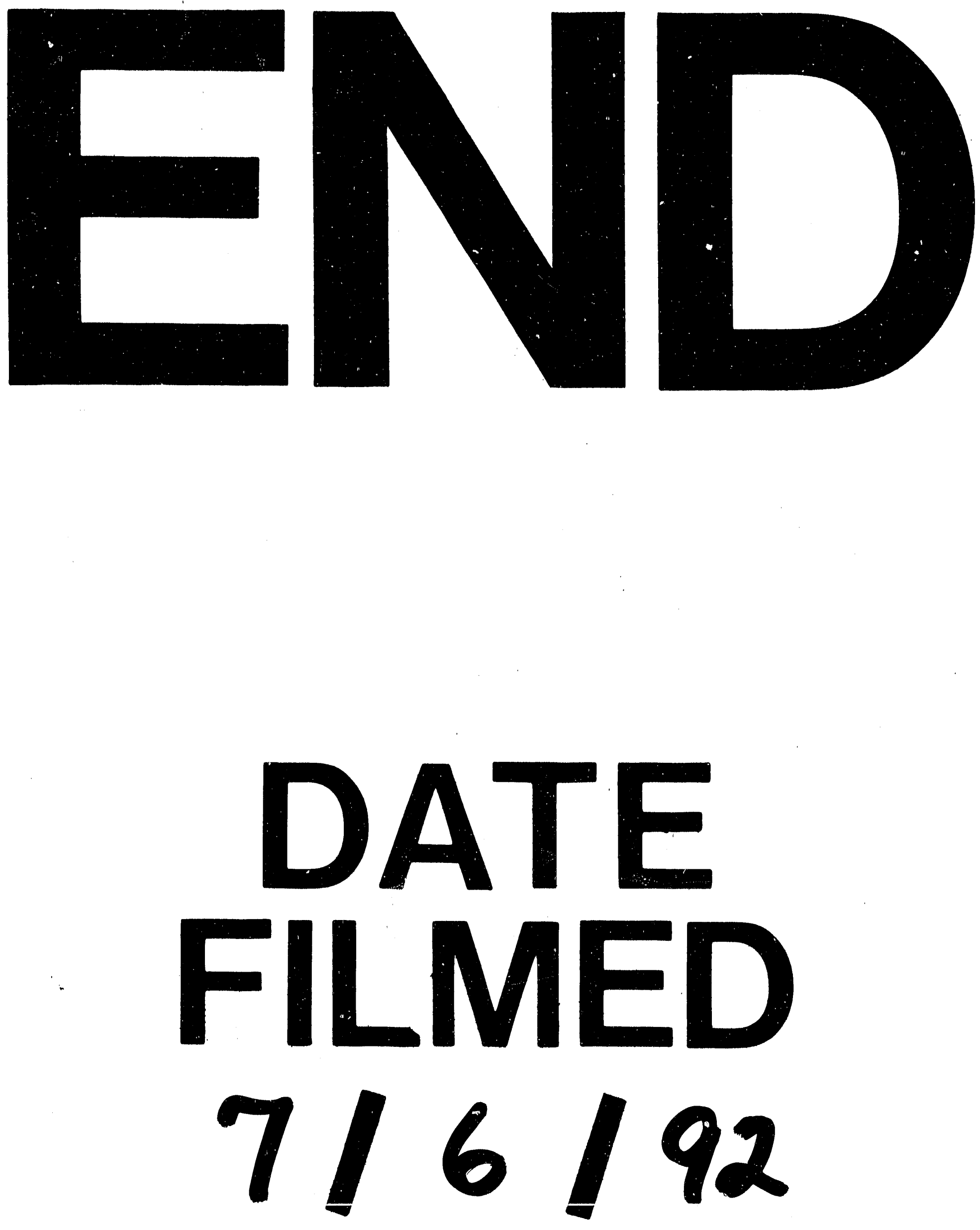

1 


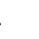

